\title{
Lietuvos bibliotekininko profesijos transformacijos: profesionalumas ir kompetencijų ugdymas
}

\author{
Daiva Janavičienè \\ Lietuvos nacionalinès Martyno Mažvydo bibliotekos \\ Informacijos ir komunikacijos mokslų departamentas \\ Department of Information and Communication Sciences \\ at the Martynas Mažvydas National Library of Lithuania \\ daiva.janaviciene@lnb.lt \\ ORCID https://orcid.org/0000-0002-0190-3573
}

\begin{abstract}
Santrauka. Straipsnio tikslas yra remiantis šiuolaikinio bibliotekininko profesionalumo samprata ir kokybiniu empiriniu tyrimu išanalizuoti Lietuvos viešųjų bibliotekų direkcijų atstovų suvokimą apie bibliotekininko profesijos transformacijas, bibliotekininko profesionalumą nurodančių kompetencijų kaitą, svarbiausias profesionalumo kliūtis ir iššǔkius. Atliktas kokybinis (empirinis) tyrimas patvirtina teorines mokslininkų įžvalgas apie bibliotekininkų profesijos transformacijas ir su tuo susijusius iššūkius. Intensyviausi pokyčiai vyksta dèl sparčiai kintančių technologijų, tačiau Lietuvos bibliotekininkai susiduria ir su politinių pertvarkų, ekonominio vystymosi netolygumų, konkurencijos apraiškomis. Nors viešosios bibliotekos vis labiau imasi lyderystės bendruomenèse vaidmens, siekia geriau pažinti ir atitikti bendruomenès lūkesčius, pripažįsta turinčios nuolat tobulinti kompetencijas ir siekti profesionalumo. Jo kaitos kliūtys reiškiasi ne tik per asmens ribotumus (konservatyvumą, nepakankamą motyvaciją tobulèti ir kt.), bet ir per objektyviai patiriamą bendros bibliotekų politikos stoką, negebejimą demonstruoti bendruomenei teikiamos naudos. Teminès analizès metodu gauta Lietuvos bibliotekininko profesionalumą žyminčių kompetencijų schema rodo, kad tyrimo dalyviai didžiąja dalimi profesionalumą suvokia per bendrąsias tradicines ir inovatyvias, kūrybiškumą bei orientaciją ị lankytoją apibrèžiančias kompetencijas. Būtina sukurti profesijos išskirtinumą sudarančių žinių ir igūudžių branduolị, kurị turètų igyti visi bibliotekose naujai įdarbinami asmenys, o dirbantys bibliotekininkai galètų daryti karjerą savo srityje pagal visiems žinomą bendrą sąsają tarp igyjamų kompetencijų ir pasiektų einant tam tikras pareigas rezultatų.
\end{abstract}

Reikšminiai žodžiai: bibliotekininko profesionalumo samprata, bibliotekininko profesijos transformacija, profesinès veiklos laukas, Lietuvos viešosios bibliotekos, kokybinis tyrimas.

\section{Transformations of the Lithuanian Librarian's Profession: Professionalism and Development of Competences}

\footnotetext{
Abstract. The objective of the article is, by drawing on the conception of professionalism of today's librarian and on qualitative empirical research, to analyse how representatives of administrations of Lithuania's public libraries perceive the transformations of the profession of a librarian, the development of competences determining the librarian's professionalism, and the main obstacles and challenges facing such professionalism. The qualitative (empirical) research that has been done substantiates theoretical insights by scholars regarding the transformations of the profession of a librarian and related challenges. The most intensive changes are determined by rapidly evolving 
technologies, but Lithuania's librarians also face certain forms of political change, economic inequality, and competition. Though public libraries are increasingly taking on the role of leaders within communities and are purporting to better comprehend communities' expectations, they acknowledge the need to continuously develop competences and seek professionalism. Obstacles hindering the development of professionalism express themselves not only through personal limitations (conservatism, insufficient motivation to improve, etc.) but also through objectively experienced lack of general library policy and inability to demonstrate the benefit provided to community. The scheme of competences determining the professionalism of Lithuanian librarians that has been drawn by applying thematic analysis shows that participants of the conducted survey perceive professionalism mostly through general traditional competences and innovative ones determining creativity and visitor orientation approach. It is essential to build a nucleus of knowledge and skills embodying the profession's exclusiveness, which all newly employed librarians should possess, and those with some length of service could pursue their careers in their appropriate fields by following the commonly known general correlation between acquired competences and achieved results from work in a certain position.

Keywords: conception of the professionalism of a librarian, transformations of the profession of a librarian, sphere of professional activity, Lithuanian public libraries, qualitative research.

\section{Ivadas}

Bibliotekos turi ilgą institucinę istoriją. Ne kartą keitėsi saugomos informacijos išteklių laikmenos, prieigos galimybès, kaupimo ir saugojimo strategijos. Moderni biblioteka globalizacijos sąlygomis (augančios informacijos išteklių apimtys, kintančios technologijos ir naujosios medijos, generacijų vertingumo pokyčiai, rinkodaros taikymas pelno nesiekiančioms institucijoms) patiria daug iššǔkių, o jiems spręsti reikalingas joje dirbančių žmonių profesionalumas. Kita vertus, nūdienos visuomenè susiduria su informacine atskirtimi, ją mažinti gali padèti kokybiškos bibliotekų paslaugos. Jų kokybei gerinti būtina nuolat atnaujinti kompetencijas, personalui būtina prisitaikyti prie kintančios aplinkos ir vartotojų poreikių. Problema yra tai, kad Lietuvoje nèra vientisos jau dirbančių bibliotekose asmenų kvalifikacijos kèlimo ar kompetencijų tobulinimo sistemos, be to, nyksta bibliotekininkystės studiju programos aukštosiose mokyklose. Bibliotekos jau susiduria ir, MOSTA tyrimo duomenimis, netolimoje ateityje dar labiau susidurs su kvalifikuotų specialistų trūkumu' Tad, atsižvelgiant ị šias aplinkybes ir perfrazuojant sociologijos klasiką M. Weberị, klaustina: kuo turi pasižymèti nūdienos bibliotekininkas, jog „būtų žmogus ir specialistas, vertas nūdienos reikalavimu“??2

Lietuvos nacionalinès Martyno Mažvydo bibliotekos Bibliotekininkystès skyrius, 2019 m. inicijavęs profesijos transformacijos tyrimą, kokybiniu tyrimu sieke išsiaiškinti bibliotekininku profesionalumo samprata ir pagrindinius veiksnius, lemiančius ju profesionaluma. Šis straipsnis ir yra vienas iš apibendrinančių šio tyrimo rezultatų. Straipsnio tikslas yra remiantis šiuolaikinio bibliotekininko profesionalumo samprata ir kokybiniu empiriniu tyrimu išanalizuoti Lietuvos viešųjų bibliotekų direkcijų atstovų suvokimą apie bibliotekininko profesijos transformacijas, bibliotekininko profesionalumą nurodančių kompetencijų kaitą, svarbiausias profesionalumo kliūtis ir iššūkius. Sistemingų, kompleksinių tyrimų straipsnio tema Lietuvoje nèra. Esama darbų, apimančių tik vieną ar kitą šio tyrimo aspektą ${ }^{3}$.

Žr. Žmogiškasis kapitalas Lietuvoje 2019: kryptis - ateities darbo rinka / apžvalgą parengė: G. Jakštas, V. Kuodytė, B. Leipute, G. Padvilikis, M. Palevič, D. Požèla, L. Sabulytė, P. Simanavičius. Vilnius: Mokslo ir studijų stebėsenos ir analizès centras, 2019, p. 16. Weber, M. Mokslas kaip profesinis pašaukimas / iš vokiečių k. vertė Z. Norkus. Problemos, 1990, t. 42, p. 82.

Bibliotekininkų (informacijos specialistų) poreikio tyrimą, taip pat ir profesinių kompetencijų analizę atliko: Augustinaitis, A.; Macevičiūtė E. Informacijos specialistų poreikio nustatymo kriterijai. Informacijos mokslai, 1996, t. 5, p. 9-20; apie bibliotekininkų profesionalumą informacinių technologijų srityje rašè: Mozūraitè, V. Laisva prieiga prie informacijos - iššūkis bibliotekininko etikai. Kultūros aktualijos, 2005, Nr. 4 (45), p. 15-17; tinklaraščių kaip komunikacijos priemonès potencialą atskleidžiant profesinès komunikacijos tendencijas analizavo: Manžuch, Z. Profesinė komunikacija teminiame bibliotekininkystės tinklaraštyje: atvejo analizè. Informacijos mokslai, 2010, t. 54, p. 115-138; struktūriškai modernaus bibliotekininko žinių sankaupa pateikta kolektyvinëje knygoje: Bibliotekininkystès ir informacijos studiju vadovas / Ats. redaktorè ir sudarytoja A. Glosienè. Vilnius: Vilniaus universiteto leidykla, 2009; bibliotekininko edukatoriaus vaidmeni ir ugdymo galimybes tyré: Grigas, V. Bibliotekininko vaidmuo informacinio raštingumo ugdymo kontekste. Bibliografija 2010/2011, 2013, p. 68-79. 
Straipsnyje profesionalo samprata apima „buvimą profesionalu, profesionalo elgesį, profesinị ịvaizdị ir statusą bei profesinį išskirtinumą kitų profesijų kontekste" ". Sampratą galima dar pildyti vieno žymiausių Lietuvos istorikų Edvardo Gudavičiaus mintimis: „profesionalumas - ne vien žinios ir sugebejjimai. Tai

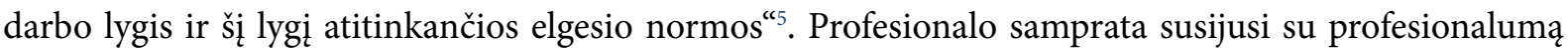
nurodančiomis kompetencijomis, apimančiomis ne tik gerai atliekamas funkcijas, bet ir profesines vertybes, asmenines nuostatas ${ }^{6}$. Tad tyrimas remiasi šiomis esminèmis bibliotekininkystès ir profesionalumo teorinèmis nuostatomis:

1) Biblioteku darbuotoju profesionalumas turi atitikti laiko dvasiq̨. Keičiantis aplinkai, bibliotekų veikloms ir čia dirbančiam personalui ne kartą teko keistis. XXI a. globalios socialinès, technologinès, medijų transformacijos kelia naujus reikalavimus ir bibliotekos institucijai. Dirbantys bibliotekoje asmenys turi suformuoti ir taikyti XXI a. adekvačius profesionalumo kriterijus7.

2) Bibliotekų darbuotojų kompetencijos turi büti tobulinamos, kad atitiktu besikeičiančius bendruomenés poreikius ir kintančiq bibliotekos filosofiją. Kaip rodo tyrimai, aplinka keičiasi, tačiau dèl prisirišimo prie stereotipų vystymasis gali būti apribotas ${ }^{8}$. Antai daugelyje posovietinių šalių bibliotekininko profesijai turi ịtakos ideologiniai pokyčiai, besikeičiantys bibliotekininko vaidmenys ir profesijai kylančios grèsmès dẻl nepakankamo nuolat kintančių technologijų îvaldymo' ${ }^{9}$ Besikeičiančios bibliotekos ir jų atsinaujinusios paslaugos turi potencijos pozityviai profesijos kaitai, tačiau kartu kelia susirūpinimą, kad profesijos srityje nę̨sivyrautų nauji, tik su technologijų îvaldymu siejami stereotipai, pamirštant esminę bibliotekų veiklos filosofiją ir vertybes ${ }^{10}$. Vis svarbesnès veikloje tampa bibliotekininko asmeninès savybès, kuriomis palaikomas profesijos autoritetas ${ }^{11}$. Profesijos tapatumas tiesiogiai susijęs su profesinemis kompetencijomis ir jų kokybe. Būti profesionaliu bibliotekininku reiškia nuolat atsinaujinti ${ }^{12}$.

3) Sèkmingai bibliotekininko profesijos transformacijai reikalinga kompetenciju tobulinimo sistema. Pastarụjų trijų dešimtmečių drastiški pokyčiai bibliotekose daugiausia susiję su informacinių ir komunikacinių technologijų kaita ir šio proceso ịtaka žinioms bei igūdžiams, kurių reikia bibliotekininkams profesionalams. Kaip minèta, Lietuvoje nykstant universitetinèms bibliotekininkystės profesinèms studijoms, iniciatyvos kurti kompetencijų plètros sistemą imasi Lietuvos nacionalinė biblioteka. $2017 \mathrm{~m}$. parengta Lietuvos viešųjų bibliotekų kvalifikacijos kèlimo sistema apima ir kompetencijų moduli. Jis orientuotas i dirbančius viešosiose bibliotekose specialistus ir fiksuoja šiose institucijose pasireiškiantị kompetencijų nepakankamumą ${ }^{13}$. Lietuvos Respublikos bibliotekų ịstatymas (LR BIt) nustato, kad apskričių viešosios bibliotekos „yra apskrities viešųjų bibliotekų metodikos, bibliografijos ir informacijos centras“14. Šio tipo

Kavaliauskienè, V. Pažintis su profesija. Klaipèda: Klaipèdos universiteto leidykla, 2011, p. 83.

Gudavičius, E. Los Caprichos. Du tūkstantis devintieji. Vilnius: Aidai, 2015, p. 364.

Žr. Šurkutè, R. Bibliotekininkų kvalifikacijos kèlimas ir kompetencijų plètra: Jungtinès Karalystès atvejis. Šiandien aktualu, 2019, Nr. 1 (60), p. 53.

Plačiau žr. Kohl, D. F. Knowledge Life Cycles: Renewal and Obsolescence. El profesional de la información, 2009, Vol. 18, No. 4, p. 374-381; Zan, B. U. Familiarity of Information and Records Management Students to Web 2.0 Tools: A Case Study on Blog. Proceedings of Global Learn Berlin 2015: Global Conference on Learning and Technology, 2015, April 16-17, p. 143-151. Prieiga per internetą: https://www.learntechlib.org/primary/p/150857/

Plačiau žr. Partridge, H.; Menzies, V.; Lee, J.; Munro, C. The Contemporary Librarian: Skills, Knowledge and Attributes Required in a World of Emerging Technologies. Library \& Information Science Research, 2010, Vol. 32, No. 4, p. 265-271.

Žr., pavyzdžiui: Haigh, M. Escaping Lenin's Library: Library and Information Science Education in Independent Ukraine. The International Information \& Library Review, 2007, Vol. 39, No. 2, p. 72-79.

10 Žr. plačiau: Vaagan, R.; Holm, S. Professional Values in Norwegian Librarianship. New Library World, 2004, Vol. 105, No. 1200/1201, p. 213-217.

11 Žr. plačiau: Hillenbrand, C. Librarianship in the 21st Century - Crisis or Transformation? The Australian Library Journal, 2005, Vol. 54, No. 2, p. 164-181.

12 Žr. Partridge, H.; Menzies, V.; Lee, J.; Munro, C. The Contemporary Librarian: Skills, Knowledge and Attributes Required in a World of Emerging Technologies. Library \& Information Science Research, 2010, Vol. 32, No. 4, p. 265-271.

13 Plačiau apie tai žr. Gudauskas, R.; Lukoševičius, R.; Knopkuvienè, V. Lietuvos viešujų biblioteku darbuotoju kvalifikacijos kèlimo sistemos modelis. Vilnius: Lietuvos nacionalinè Martyno Mažvydo biblioteka, 2017. Prieiga per internetą: https://www.kulturostyrimai.lt/metai/2017/lietuvos-viesuju-biblioteku-darbuotoju-kvalifikacijos-kelimo-sistemos-modelio-sukurimas/.

14 LR BI 8 str. 
bibliotekų veiklos kryptys numato ir neformaliojo švietimo programų rengimą ir vykdymą. Tačiau problema matytina tame, kad nèra visuotinès bibliotekų darbuotojų kompetencijų ugdymo ir tobulinimo sistemos šalyje.

Lietuvos bibliotekininko profesijos transformacijos kokybinis tyrimas grindžiamas besikeičiančioje bibliotekos institucijoje dirbančiam personalui reikalingų kompetencijų identifikacija. Giluminiuose interviu su tyrimo dalyviais gvildenami profesionalumui svarbūs aspektai. Tyrimas atliktas remiantis ontologine, epistemiologine, konstruktyvistine, idealizmo ir pragmatizmo nuostatomis. Vadovaujantis ontologine nuostata realybė yra traktuojama kaip įvairialypė. Remdamasis epistemiologine nuostata tyrẻjas siekia būti empatiškas tyrimo dalyviams ir atspindi individualias jų nuostatas. Konstruktyvizmo ir idealizmo idejos paremtos nuostata, kad socialinių fenomenų prasmė yra sukuriama dalijantis supratimu arba interpretacija, konstrukcijos yra subjektyvios prigimties, o subjektyvios nuostatos yra svarbi sistemos dalis. Pasitelkiama pragmatizmo nuostata, kurios pagrindu tyrimo metodai pasirenkami pagal tyrimo tikslus ${ }^{15}$.

Duomenys analizuoti teminès analizės metodu, pasitelkiant žinojimo sociologijos prieigą. Laikytasi nuostatos, kad realybė yra socialiai konstruojama ${ }^{16}$. Tad tyrimu siekta suprasti tyrimo dalyvių suvokimą apie profesijos transformacijas ir profesionalumą, su kokiomis problemomis jie susiduria ir kaip jas sprendžia $^{17}$. Taikyta indukcinè tyrimo perspektyva, kai „tyrèjas susipažǐsta su tyrimo medžiaga $<\ldots>$, ieško joje raktinių sąvokų arba prasmių, kurias galètų konceptualizuoti ir interpretuoti <...> analizuodamas duomenis atsiriboja nuo egzistuojančiu teorinių modelių <...> ${ }^{\text {"18 }}$. Tyrejjo kūrybingumas ir subjektyvumas analizuojant tyrimo duomenis laikomi TA [teminès analizès metodo] privalumu ${ }^{19}$.

Straipsnis sudarytas iš trijų dalių. Pirmoje teorinèje dalyje pristatomi pagrindiniai teoriniai šaltiniai (kuriais remtasi apibrežiant šiuolaikinę bibliotekininko profesijos sampratą), išskiriami bibliotekininkų profesionalumo aktualumą pagrindžiantys veiksniai. Svarbiausią vaidmenį čia vaidina Izraelio mokslininkès Jenny Bronstein tyrimai ir idejos. Ši dalis skirta konceptualiam problemos pagrindimui. Antra straipsnio dalis (didžiausia apimties požiūriu) - empirinio tyrimo pristatymas ir rezultatų pateikimas. Šios dalies pradžioje formuluojamas kokybinio tyrimo tikslas, aptariama imties atranka, informacijos rinkimo būdas. Išsamiai pristatomos tyrimo dalyvių demografinès charakteristikos, interviu loginè seka ir klausimai, struktūruoto interviu techniniai apimties duomenys, kokybinio tyrimo eiga. Šios straipsnio dalies pabaigoje pateikiami empirinio tyrimo rezultatai. Jie struktūruojami per duomenų kodavimu ir jų analize sugeneruotas temas ir jų vidinès struktūros atskleidimą. Siekiant aiškesnio visumos suvokimo, temos skirstomos ị potemes, atskleidžiant vidinius jų aspektus. Atskleidus temas (Svarbiausios veiklos bibliotekose; Profesionalumo kaitos veiksniai, iššūkiai ir kliūtys; Profesionaluma išreiškiančios kompetencijos; Profesionalumo reikalavimai ir Profesionalumo vystymas) trečioje (paskutinejje) straipsnio dalyje apibendrinamos temos, interpretuojami surinkti duomenys, sprendžiami iškylantys diskusinio pobūdžio klausimai bei pateikiama Lietuvos bibliotekininko profesionalumą žyminčių kompetencijų klasifikacija (1 schema). Straipsnis baigiamas išvadų ir rekomendacijų pateikimu.

Šio straipsnio naujumą ir aktualumą rodo šie aspektai: 1) pirmas sisteminis bandymas pateikti nūdienos Lietuvos bibliotekininko profesionalumo sampratą; 2) indèlis ỉ profesinès veiklos lauko tyrimus ${ }^{20}$.

Plačiau žr. Žydžiūnaite, V.; Sabaliauskas, S. Kokybiniai tyrimai: principai ir metodai. Vilnius: Vaga, 2017, p. 41-45.

Plačiau apie tai žr. Berger, P. L.; Luckmann, T. Socialinis tikrovés konstravimas: žinojimo sociologijos traktatas / iš anglų k. vertė A. Radžvilienè. Vilnius: Pradai, 1999.

Plg. Žydžiūnaitè, V.; Sabaliauskas, S. Kokybiniai tyrimai: principai ir metodai, p. 46.

Ibidem, p. 210.

Žr. ibidem, p. 224.

Plačiau apie profesinès veiklos lauko kaip atskirą profesijų sociologijos tyrimų sriț žr. Poviliūnas, A.; Žiliukaitė, R.; Beresnevičiūtė, V. Profesinès veiklos lauko tyrimas. Vilnius: Vilniaus universiteto leidykla, 2012. Profesinès veiklos lauko tyrimų pavyzdžiai: Navickienè, Ž.; Žiemelis, D. Lietuvos teisejų profesionalumo dimensijos: kvalifikacija, kompetencija ir asmeninès savybės. Teisé, t. 97, 2015, p. 183-199; Šermukšnytė, R. Ar istorijos mokytojams Lietuvoje reikia akademinės istorijos ir akademinių istorikų? Istorija, 2020, t. 120, Nr. 4, p. 67-102. 


\section{Bibliotekininko profesionalumo samprata teoriniuose profesijos transformacijos tyrimuose}

Biblioteka kaip institucija turi ilgą istoriją - tvarkomi dokumentų rinkiniai yra žinomi nuo šumerų civilizacijos molinių lentelių rinkinio. Vadinasi, bibliotekos užuomazgos siekia jau trečią tūkstantmetị prieš mūsų erą. Kaip žinia, didelis dokumentų kiekis turi būti valdomas tą veiklą išmanančių žmonių, kitaip informacija pasimes, ją bus sudetinga surasti reikiamu laiku. Taigi logiška, kad bibliotekininko (dokumentų tvarkytojo, klasifikuotojo ir prižiūrètojo) amatas ir iš to išsivysčiusi profesija turi gilias šaknis. Dokumentų laikmenos keičiasi, medijos, kuriomis naudojasi informacijos naudotojai (sąvokos „naudotojai“ ir „vartotojai“ skirtingose bibliotekininkystès srityse ir kontekstuose turi skirtingas reikšmes ir gali büti skirtingai suvokiamos) kinta, bet poreikis atrinkti, vertinti, klasifikuoti, sisteminti ir kitaip valdyti turimus dokumentus išlieka. Tiesa, kinta ne tik valdymo turinys - ivairiose laikmenose fiksuotas turinys, bet ir informacijos valdymo procesas. Pavyzdžiui, skirtingų igūdžių reikia tvarkyti rankraščiu kolekcijai senovės istorijos laikotarpiu ir vinilinių plokštelių kolekcijai XX a. viduryje. Organizuojant rankraščių biblioteką, svarbiausias aspektas būtų perrašyti rankraščius, taip didinant turimos kolekcijos apimtį ir vertę. Tam bibliotekas kuriantys valdovai siųsdavo raštą mokančius skriptorius ị ilgas keliones, ten, kur yra vertingas dokumentas. I reikiamą vietą nuvykęs vietinę kalbą mokantis skriptorius vieną knygą perrašinėdavo ilgus mėnesius. Kaupiant vinilinių plokštelių kolekciją svarbu ne tik atrinkti dokumentus pagal kaupiamos kolekcijos profilị (nes muzikinių įrašų parduodama milijonai pavadinimų), bet ir turèti technologinę ịrangą ịsigytoms plokštelėms naudoti. Pastarasis (medijų ir technologijų kaitos) aspektas ypač aktualus tampa XXI a. Laikmenos keičiasi nespejjusios visuotinai issigalèti, naujos technologijos lenkia viena kitą, tapdamos pelną duodančių inovacijų šaltiniu konkuruojančioms firmoms. Didejantys informacijos kiekiai kelia naujas informacijos valdymo problemas. Šiuolaikiniame pasaulyje informacijos yra per daug, šiame kiekyje susiduriame su kokybiškos ir tinkamos informacijos atrankos problema. Be to, kokybiškos informacijos prieigą kai kuriems visuomenès sluoksniams riboja visuomeneje pasireiškianti technologinio raštingumo atskirtis. Naujai kylantys informacijos valdymo iššūkiai aktualūs bibliotekoms. Tam, kad jų darbuotojai galètų sèkmingai juos spręsti, būtinas naujas žvilgsnis ị bibliotekininkui būtinas kompetencijas.

Bibliotekininku profesionalumo problemos aktualuma lemia daugelis veiksnių. Remiantis tyrimais ${ }^{21}$, tai yra šie veiksniai:

1) jau igiję bibliotekininko profesiją ir dirbantys bibliotekose asmenys turi atnaujinti kompetencijas;

2) Lietuvoje nyksta bibliotekininko profesijai igyti skirtos ilgalaikès studijos;

3) šalyje viešųjų bibliotekų skaičius išlieka gana didelis ir jose teikiamomis paslaugomis naudojamasi itin daug. 2018 m. „Bibliotekų statistikos“ duomenimis, Lietuvoje buvo 1236 viešosios bibliotekos, o besinaudojančių šiose bibliotekose teikiamomis paslaugomis (registruotų vartotojų) $2018 \mathrm{~m}$. buvo daugiau nei pusé milijono (541 508), apsilankymų skaičius per $2018 \mathrm{~m}$. perkopè 9 milijonus $(9260638)^{22}$

4) bibliotekos transformuojasi ne tik dèl kintančių medijų, bet ir dèl besikeičiančių bendruomenių poreikių;

5) didejja bibliotekų paslaugų ịvairové, vis daugiau paslaugų skiriama valdomų informacijos išteklių naudojimui skatinti;

\footnotetext{
Žr. Stasėnaitè, V; Naujokienė, L. Informacijos paslaugų specialistų poreikio integralumas informacinès visuomenès plètroje pereinant $\mathfrak{i}$ skaitmeninę globalios atminties erdvę. Profesinés studijos: teorija ir praktika, 2012, t. 9, p. 123-133; Gudauskas, R.; Lukoševičius, R.; Knopkuvienè, V. Lietuvos viešujų bibliotekų darbuotojų kvalifikacijos kèlimo sistemos modelis; Bronstein, J. An Exploration of the Library and Information Science Professional Skills: An Israeli Perspective. Library \& Information Science Research, 2015, Vol. 37, No. 2, p. 130-138; Manžuch, Z. Profesinè komunikacija teminiame bibliotekininkystés tinklaraštyje: atvejo analizé, p. $115-138$.

22 Lietuvos biblioteku statistiniai duomenys. 2018. Prieiga per internetą: https://lnb.lt/media/public/bibliotekininkui/statistika/statistika2018.pdf.
} 
6) bibliotekininkai pasigenda kvalifikacijos kèlimo / kompetencijų ugdymo ir tobulinimo sistemos;

7) Lietuvoje trūksta vizijos, formuojančios bibliotekininko profesijos tapatumą.

Teorinè bibliotekininko profesijos kompetencijų analizė identifikuoja bendras XXI a. būdingas profesijų sampratos transformacijas. V. Kavaliauskienès tyrimas rodo, kad tam įtaką daro: 1) socialinès transformacijos (migracija, ilgèjantis darbingas žmogaus amžius, mažèjantis gimstamumas); 2) technologinès transformacijos (dẻl informacinių ir komunikacinių technologijų dirbti galima iš bet kur); 3) kompetenciju transformacijos, kai vertinamas ne žinojimas, o gebejimas taikyti igūdžius įvairiose veiklose; 4) trumpalaikių i̇darbinimo sutarčių praktika, nemotyvuojanti igyti profesionalumo konkrečioje srityje / darbo vietoje $\mathrm{e}^{23}$.

Bibliotekininko profesijos kaitos analizè atskleidè, kad jau XX a. 8 dešimtmetyje mokslininkai ir praktikai perspejjo apie profesijai kylančias išnykimo grèsmes ir poreikị transformuotis. XXI a. tyrimai kalba apie įtakas profesijos kaitai ir skatinimus tinkamai reaguoti i jas ${ }^{24}$. Ekonomiškai stiprių šalių mokslininkai siūlo bibliotekoms siekti ekonominio rentabilumo, konkuruoti tarpusavyje, imtis lyderystès bendruomenèse vaidmens ${ }^{25}$. Tyrimai rodo, kad aktualiausios pokyčių tendencijos susijusios su naujųjų medijų ir technologiju ívaldymo svarba ${ }^{26}$.

Apibrezžiant bibliotekininko profesinę veiklą ịvardijamos tokios tradicinès bibliotekininko darbo funkcijos: informacijos atranka, įsigijimas, organizavimas ir pateikimas skaitytojams arba knygų sklaidos organizavimas, informacijos apie bibliotekoje saugomus rinkinius sklaida skaitytojams ${ }^{27}$. Pabrēžiamos pagrindinès etinès ir profesinès vertybès: tarnystė bendruomenès nariams (angl. patron service), intelektualinè laisvè, dokumentų išsaugojimas, lygiateisès prieigos galimybės ir informacinis raštingumas. Vis svarbesnès bibliotekininko veikloje tampa jo asmeninès savybès, kuriomis palaikomas profesijos autoritetas $^{28}$.

Aptardami bibliotekininkų kompetencijų tęstinumą ir kaitą, bibliotekininkai praktikai ir teoretikai kelia mintị apie būtinybę imtis naujų veiklos būdų, reaguojant ị besikeičiančias technologijas. Tai ne tik turimų kolekcijų perkèlimas į naujas laikmenas, bet ir mokymų ir instruktavimų bendruomenei vystymas, pasitelkiant informacinio ir technologinio raštingumo igūdžių ugdymą. Tokiu būdu šios srities mokymai papildytų jau esamas bibliotekų paslaugas ${ }^{29}$.

Ypatinga vieta bibliotekininkui būtinų kompetencijų sąraše skiriama asmeniniams gebëjimams, kurie glaudžiai persipina su profesiniais gebejimais. Esmines bibliotekininko profesionalumui svarbias kompetencijas sudaro: (1) tarpasmeninès komunikacijos igūdžiai tiesiogiai ir internetu; (2) vadybiniai igū-

Plačiau žr. Kavaliauskienė, V. Pažintis su profesija, p. 23-25.

4 Plačiau žr. Smalls, M. L. The Library Proffesion in the 21th Century: Transformation for Survival. Paper presented at the Annual Meetingof the Georgia Library Association, 1985, August, GA, October 25, p. 1-16. Prieiga per internetą: https://files.eric.ed.gov/ fulltext/ED267818.pdf.; Castiglione, J. Environmental Scanning: an Essential Tool for Twenty First Century Librarianship. Library Review, 2008, Vol. 57, No. 7, p. 528-536; Johnson, C. A. Library and Information Science Education in Developing Countries. The International Information \& Library Review, 2007, Vol. 39, No. 2, p. 64-71; Zan, B. U. Familiarity of Information and Records Management Students to Web 2.0 Tools: A Case Study on Blog, p. 143-151; Gudauskas, R.; Lukoševičius, R.; Knopkuviené, V. Lietuvos viešujų biblioteku darbuotojų kvalifikacijos kèlimo sistemos modelis.

25 Žr. Partridge, H.; Menzies, V.; Lee, J.; Munro, C. The Contemporary Librarian: Skills, Knowledge and Attributes Required in a World of Emerging Technologies, p. 265-271; Kohl, D. F. Knowledge Life Cycles: Renewal and Obsolescence, p. 374-381; Johnson, C. A. Library and Information Science Education in Developing Countries, p. 64-71.

26 Žr. Hillenbrand, C. Librarianship in the 21st Century - Crisis or Transformation?, p. 164-181; Castiglione, J. Environmental Scanning: An Essential Tool for Twenty First Century Librarianship. Library Review, 2008, Vol. 57, No. 7, p 528-536; Stasenaite, V.; Naujokiené, L. Informacijos paslaugų specialistų poreikio integralumas informacinės visuomenès plètroje pereinant ị skaitmeninę globalios atminties erdvę, p. 123-133.

27 Plačiau žr. Hillenbrand, C. Librarianship in the 21st Century - Crisis or Transformation?, p. 164-181; Glosienè, A. Biblioteka informacijos politikos kontekste. Informacijos mokslai, 2000, t. 15, p. 11-27.

28 Žr. Vaagan, R.; Holm, S. Professional Values in Norwegian Librarianship, p. 213-217; Stasėnaitė, V.; Naujokienė, L. Informacijos paslaugų specialistų poreikio integralumas informacinès visuomenès plètroje pereinant ị skaitmeninę globalios atminties erdvę, p. 123-133.

29 Plačiau žr. Bronstein, J. An Exploration of the Library and Information Science Professional Skills: An Israeli Perspective, p. 130-138. 
džiai; (3) atnaujinami papildomi igūdžiai (IT programų valdymas, mokymai ir pan.); (4) informacijos vadyba; (5) inovatyvumas, adaptyvumas ir kitos asmens savybès ${ }^{30}$.

Išanalizavusi IFLA tinklalapyje pateikiamus bibliotekininkų darbo skelbimus mokslininkẻ Bendja Boumarafi išskyrè tris pareigybių, ị kurias buvo ieškoma kandidatų, grupes: 1) informacinemis komunikacinėmis technologijomis grịstų paslaugų teikimas (programavimas ir pan.); 2) informacijos teikimo vartotojams paslaugų teikimas (mokymai ir pan.);3) pareigos, skirtos techninėms-bibliotekinėms paslaugoms (katalogavimas, bibliografavimas ir pan.). Kaip atskirą sritį mokslininkẻ išskiria asmeninių igūdžių svarbą reikalavimuose eiti pareigas ${ }^{31}$. Pasinaudodama šia struktūra, Izraelio bibliotekininkystès srities mokslininkẻ Jenny Bronstein pasiūlè profesinių bibliotekininkų igūdžių tipologiją, kurią sudaro keturios pagrindinès grupès: 1) informacijos teikimo / aprūpinimo igūdžiu rinkinys (angl. information provision); 2) informacijos organizavimo igūdžių rinkinys (angl. organization of information); 3) technologiniu ịūdžiu rinkinys (angl. technological skills); 4) asmeninių kompetencijų rinkinys (angl. personal competen(ies) ${ }^{32}$. Pirmoje lentelejje atspindèta visa J. Bronstein sudaryta šiuolaikiniams bibliotekininkams būtinų kompetencijų tipologija, apimanti išskirtas esmines grupes, jas sudarančius ịgūdžius ir jų detalizavimą.

1 lentelè. Bibliotekininkystès specialistu kompetenciju tipologija (pagal J. Bronstein, 2015, p. 136-137)

\section{Igūdžiai} (angl. reference skills)

2 Vartotojų aptarnavimas

3 Instruktavimo gebejjimai

4 Informacijos tikslinimo / poreikių identifikavimo igūdžiai

5 Tiriamieji informacijos paieškos igūdžiai

6 Duomenų analizès ir ataskaitos rašymo ịgūdžiai

7 Informacijos paieškos ir pateikimo igūdžiai

8 Informacijos paieškos duomenų bazèse igūdžiai

\section{Apibūdinimas}

\section{nformacijos paslaugų teikimo kompetencijų grupé}

Gebejjimai užduoti tikslinančius klausimus ir išmanyti informacijos teikimo, naudojantis ịvairiais šaltiniais, technologijas

Gebejimai atsakyti ị nesudètingas informacijos užklausas (suteikti pradinio informacinio aptarnavimo paslaugas skaitytojams)

Gebejjimai instruktuoti vartotojus apie informacijos paieškos būdus

Gebejjimai suvokti skaitytoju poreikius ir sudaryti informacijos paieškos planą, atitinkanti skaitytojo poreikius ir iš bibliotekos prieigos pasiekiamus informacijos šaltinius

Gebejjimai atlikti sudètingos informacijos paiešką pagal aukštesnio lygio (gilesnès) informacijos užklausas skaitytojams

Gebejimai analizuoti ir interpretuoti kiekybinius ir kokybinius duomenis, suformuojant atliktų informacijos paslaugų reprezentaciją

Igūdžiai atlikti informacijos paiešką ịvairiuose šaltiniuose, surinkti ir apibendrinti informaciją

Igūdžiai taikyti įvairias informacijos paieškos strategijas skirtingose duomenų bazèse

\section{Informacijos organizavimo kompetencijų grupé}

9 Katalogavimas

10 Periodinių leidinių vadyba

11 Informacijos rinkiniu vystymas (fondų komplektavimas)
Gebejjimai kurti katalogų ịrašus (bibliografinio aprašymo, dalykinimo ir klasifikavimo ịgūdžiai)

Gebejjimai atlikti periodinių leidinių valdymo operacijas (užprenumeruoti, sekti gavimą, pateikti reikalavimus leidejams, ịrišti rinkinius ir juos saugoti (angl. subscribing, claiming, binding, preserving) Gebejimai atrinkti, užsakyti ir įsigyti įvairius informacijos išteklius bibliotekai (pagal dokumentų rūšis, laikmenas, medijas)

\footnotetext{
${ }^{30}$ Žr. Partridge, H.; Menzies, V.; Lee, J.; Munro, C. The Contemporary Librarian: Skills, Knowledge and Attributes Required in a World of Emerging Technologies, p. 265-271; Bronstein, J. An Exploration of the Library and Information Science Professional Skills: An Israeli Perspective, p. 130-138.

31 Žr. Boumarafi, B. Linking Library Profession and the Market Place: Finding Connections for the Library in the Digital Environment. QScience Proceedings: The SLA-AGC 21st Annual Conference, 2015, Vol. 2015, No. 4, p. 1-8.

32 Bronstein, J. An Exploration of the Library and Information Science Professional Skills: An Israeli Perspective, p. 136-137.
} 


\section{Igūdžiai}

12 Klasifikavimas

13 Žinių vadyba

14 Dalykinimas, indeksavimas (angl. indexing)

15 Informacijos organizavimas

17 Bibliotekinių kompiuterinių programų naudojimas ir atnaujinimas

18 Turinio valdymas

19 Tinklo valdymas

20 Darbas su socialiniais tinklais internete

21 Duomenų bazių valdymas

22 Svetainių dizaino kūrimas

23 Interneto naudojimo ịgūdžiai

24 Projektų vystymas

25 Kompiuterių naudojimo ịgūdžiai

26 Tinklalapio valdymas

27 Programavimo ịgūdžiai

28 Duomenų bazių projektavimas (angl. design)

\section{Apibūdinimas}

Gebejimai pagal iš anksto nustatytus klasifikavimo sistemos rèmus ir tikslus suklasifikuoti dokumentus, kad būtų paprasčiau atlikti informacijos paiešką ir dokumentai būtų geriau pasiekiami vartotojams

Gebejjimai valdyti organizacijoje sukurtas žinias

Gebejimai suteikti informacijai dalykines rubrikas ar klasifikacijos indeksus ir papildyti bibliotekos dalykinių rubrikų duomenų bazę ar tezaurą

Susipažinimas su tradicinèmis informacijos organizavimo priemonėmis (dokumentų žymèjimas, sustatymas į lentynas ir kt.)

\section{Technologinių kompetenciju grupé}

Igūdžiai tobulinti ir papildyti duomenimis bibliotekos tinklalapi

Gebejimai ịkelti duomenis ir rasti informaciją bibliotekoje veikiančiose bibliotekinèse programose

Gebejjimai kurti, redaguoti, publikuoti, išsaugoti ir valdyti tinklalapių turinị

Gebejjimai valdyti fizinèje erdvèje esančių kompiuterių grupę, susiejant juos taip, kad būtų galima pasidalyti duomenimis, dažniausiai tam panaudojant telekomunikacijos ryšius ir klientų (serverių) infrastruktūros architektūrinị išsidèstymą

Gebejimai naudotis įvairiais socialiniais tinklais

Gebejjimai valdyti ir palaikyti duomenų bazes

Gebejimas kurti bibliotekos svetainių dizainą

Gebejjimai efektyviai naudoti informacijos išteklius internete

Gebejjimai planuoti, organizuoti, motyvuoti, kontroliuoti išteklių naudojimą, procedūras ir protokolus siekiant specifinių tikslų

Gebejimai efektyviai naudoti kompiuterius ir su jais susijusias technologijas, pradedant elementariu programavimo igūdžių lygiu ir pažengusiųų lygiu sprendžiant iškilusias problemas

Gebejimai palaikyti ir valdyti tinklalapi

Gebejjimai sukurti programą, kad duomenis būtų galima apdoroti kompiuteriu

Gebejimai suprojektuoti ir sukurti duomenų bazes

\section{Reikalingų asmeninių kompetencijų grupé}

29-49 Mokèti užsienio kalbą, savarankiškumas, orientacija ị paslaugų teikimą, iniciatyvumas, kruopštumas, tarpasmeninių ryšių palaikymas, savarankiškas mokymasis, atsakingumas, grupinio darbo igūdžiai, atkaklumas ir tikslo siekimas (angl. assertiveness), organizaciniai gebejimai, daugiatikslingumas, pasiryžimas dirbti lanksčiu grafiku, darbo bibliotekoje patirtis, vadybos igūdžiai, rinkodara, ryšiu palaikymas (angl. liaison), komunikacijos ịgūdžiai, orientacija ị technologijas, gebejjimai dirbti jaučiant spaudimą, valdymo patirtis

Pateikta tipologija pasitelkiama kaip bibliotekinkystès specialistų kompetencijų teorinis modelis, kuriuo remiantis ir formuluojami šio tyrimo interviu klausimai. Empiriniame tyrime naudojant indukcinę duomenų analizės perspektyvą, nuo sukauptų teorinių žinių stengiamasi atsiriboti, o sukauptą informaciją analizuoti pagal teminès analizès technologiją, t. y. „atsiribojama nuo egzistuojančių teorinių modelių “33, atliekama temų paieška, kuriama klasifikacija pagal autentiškas tyrimo dalyvių nuomones.

Žydžiūnaitė, V.; Sabaliauskas, S. Kokybiniai tyrimai: principai ir metodai, p. 210. 


\section{Kokybinis teminès analizès tyrimas}

\subsection{Interviu metodai, dalyviu atranka ir klausimai}

Surinkti duomenys išanalizuoti pasitelkiant teminès analizės metodą. Taikant indukcinę perspektyvą, temos formuojamos atsiribojant nuo išankstinių modelių. Gilinantis ị interviu tekstus, duomenys koduojami, ieškant juose reikšminių sąvokų ir prasmių. Koduojant autentiškas tyrimo dalyvių nuomones, suformuotos 5 esminès temos: 1) Svarbiausios veiklos bibliotekose; 2) Profesionalumo kaitos veiksniai, iššūkiai ir kliūtys; 3) Profesionaluma išreiškiančios kompetencijos; 4) Profesionalumo reikalavimai ir 5) Profesionalumo vystymas. Kiekvienoje temoje yra po 3-4 potemes, kuriose atskleidžiami temai būdingi aspektai.

Svarbiausios veiklos bibliotekoje skirstomos ị tradicijų puoselejimui ir inovacijoms atstovaujančias bibliotekų veiklas bei sąlygas, kuriomis tos veiklos vykdomos. Profesionalumo kaitos veiksniai, iššūkiai ir kliūtys atskleidžiami per kaitą lemiančius veiksnius, pokyčių kelyje sprendžiamus iššūkius ir sutinkamas kliūtis. Profesionaluma išreiškiančios kompetencijos aptariamos skirstant jas i tradicines (klasikines) profesijai būdingas kompetencijas; inovatyvioms veikloms būtinas kompetencijas bei profesionaliai dirbančiam bibliotekininkui būdingas asmenines savybes (bendruosius gebejjimus). Pabrěžiama sąlygų profesionalumo raiškai svarba. Profesionalumo reikalavimai analizuojami per jų išraišką priimant j darbą bibliotekoje ir mąstant apie jau dirbančių bibliotekoje žmonių kompetencijų ugdymą, sistemos šiame procese būtinumą. Reikalavimų neapibrèžtumas suponuoja profesijos neapibrěžtumo problemą ir poreikị apibrèžti profesijos tęstinumo siekius. Profesionalumo vystymo temoje samprotaujama apie profesionalumo priežastis ir sąlygas, aptariami kompetencijų tobulinimo būdai, įvardijamos dirbantiems bibliotekininkams svarbios ir tobulintinos kompetencijos.

Kokybinio tyrimo tikslas - išsiaiškinti Lietuvos viešųjų bibliotekų administracijos darbuotojų suvokimą apie bibliotekininko profesijos transformacijas ir bibliotekininko profesionalumą, taip pat tai nurodančių kompetencijų kaitą.

Imties atranka siekiama reprezentatyvaus nagrinejjamos problemos atspindèjimo, pasirinktas tipiniu atvejų atrankos büdas. Ši atranka taikoma siekiant iliustruoti tam tikrai aplinkai būdingą informaciją Konsultuojantis su Lietuvos nacionalinès Martyno Mažvydo bibliotekos Bibliotekininkystės skyriaus vadovais, sudarytas tyrimo dalyvių sąrašas, užtikrinantis viešųjų bibliotekų geografinị išsidèstymą (dalyviai iš skirtingų Lietuvos regionų), viešųjų bibliotekų specifiškumą (miestų, rajonų, kurortų, apskričių viešosios bibliotekos). Pasirinkta imtis (dešimt tyrimo dalyvių: viešujų bibliotekų direkcijos atstovai, atsakingi už personalo formavimą) užtikrina duomenų kiekị ir yra pakankama temoms formuluoti bei išsamiai tyrimo ataskaitai pateikti.

Informacijos rinkimo būdas - tiesioginis pokalbis su tyrimo dalyviais jiems ịprastoje aplinkoje, tyrejui nuvykstant ị susitikimą konkrečioje bibliotekoje. Pokalbis įrašomas diktofonu, paskui transkribuojamas ir analizuojamas.

Visi tyrimo dalyviai iš anksto informuoti apie tyrimo tikslą, jie pasiraše sutinkantys dalyvauti tyrime, kurio konfidencialumo ribos buvo apibrëžtos. Keletas tyrimo dalyvių pageidavo išsaugoti konfidencialumą, todèl visa informacija pateikiama dalyviams suteikiant kodus. Surinkti duomenys saugomi Nacionalinès bibliotekos Bibliotekininkystès skyriuje ir prieinami tik tyrimo tikslais.

Tyrimo dalyviai - Lietuvos viešųjų bibliotekų direkcijų atstovai, atsakingi už personalo formavimą. Jų demografinès charakteristikos:

1. TD1 - 37 metų moteris

2. TD2 - 64 metų moteris

Žr. ibidem, p. 62. 
3. TD3 - 57 metų moteris

4. TD4 - 64 metų vyras

5. TD5 - 56 metų moteris

6. TD6 - moteris (amžiaus nesutiko atskleisti)

7. TD7 - 60 metų moteris

8. TD8 - 48 metų moteris

9. TD9 - 59 metų moteris

10. TD10 - 48 metų moteris

Duomenims rinkti pasirinktas pusiau struktūruoto interviu būdas pagal iš anksto parengtą klausimų sąrašą ir jų pateikimo tvarką, paliekant tyrèjui galimybę užduoti papildomų klausimų, patikslinti. Pokalbis nebuvo formalizuotas, išlaikytas abipusis laisvumas ir draugiška atmosfera.

\section{2 lentelè. Struktūruoto interviu loginè seka ir klausimai}

\begin{tabular}{l} 
Klausimas \\
\hline Kokios veiklos bibliotekoje yra svarbiausios? \\
\hline Kas yra bibliotekininko profesionalumas? \\
Kokios kompetencijos būdingos profesionaliam bib- \\
liotekininkui? Kaip ši samprata pasikeite (lyginant \\
savo veiklos pradžią ir XXI amžių)?
\end{tabular}

Kaip profesionalumo reikalavimai priklauso nuo to, kuriame bibliotekos padalinyje bibliotekininkas dirba? Kaip tai pasireiškia (apibūdinkite)?

Kokius bibliotekininko profesionalumo lygius galètumète išskirti?

Kokioms kompetencijoms teikiate pirmenybę, priimdami naujus darbuotojus?

Kokias minimalias žinias ir kompetencijas turi turèti naujai įdarbinamas ị bibliotekininko (ar jam tolygias) pareigas asmuo (iš tyrimo dalyvių patirties, kaip praktika keitèsi per 10 metų)?

Kokių kompetencijų trūksta ir kokias reikètų ugdyti jau dirbantiems bibliotekoje?

Kaip kompetencijų ugdymą ir jų tobulinimą galètumète susieti su kokia nors (galima) jų ugdymo sistema, skirtingais lygiais? Su motyvavimo sistema kokia ji turètų būti? Ko trūksta, kad dabar įdarbinti darbuotojai tobulintų reikalingas kompetencijas?

\section{Kokius duomenis siekiama surinkti}

Generuoti suvokimą, kaip keičiasi suvokimas apie pagrindines bibliotekų funkcijas ir veiklas

Generuoti suvokimą apie svarbiausių veiklų ir ne tik jų atlikimo kokybinius veiksnius

Generuoti suvokimą apie tai, kaip keitèsi bibliotekininkams būtinos kompetencijos ir kokių kompetencijų pasigendama dabar

Generuoti suvokimą apie padalinių ir atskirų bibliotekininkų profesionalumo skirtumus

Generuoti suvokimą apie skirtingai pasireiškiantị profesionalumą

Surinkti informaciją apie patirtį ir kriterijus, kurie yra taikomi dabar pasirenkant darbuotojus

Generuoti suvokimą apie būtiną ir pakankamą išsilavinimą, ịsidarbinant bibliotekininku

Generuoti suvokimą apie dabartinių bibliotekos darbuotojų poreikį ugdyti konkrečias kompetencijas

Generuoti suvokimą apie galimą profesionalumo sistemą ir jos elementus

Ilgiausias interviu truko beveik 2 valandas ( 1 val. 49 min. 56 sek.), trumpiausias - 34 min. 42 sek. Vidutinè interviu trukmè - 54 min. Transkribuoto teksto (iš viso) apimtis - 331374 spaudos ženklai. Skaičiuojant vienam A4 formato lapui 1800 spaudos ženklų, visa transkribuoto teksto apimtis - 184 puslapiai. 
3 lentelè. Tyrimo dalyvių struktūruoto interviu techniniai duomenys

\begin{tabular}{|c|c|c|c|}
\hline $\begin{array}{l}\text { Tyrimo dalyvio } \\
\text { kodas }\end{array}$ & Interviu trukmè (min.) & $\begin{array}{l}\text { Transkribuoto teksto dydis } \\
\text { (spaudos ženklais) }\end{array}$ & $\begin{array}{l}\text { Transkribuoto teksto } \\
\text { dydis (A4 lapais) }\end{array}$ \\
\hline TD1 & 37 min. 47 sek. & 27164 sp. ž. & $7 \mathrm{p}$. \\
\hline TD2 & 34 min. 42 sek. & 21565 sp. ž. & $6 \mathrm{p}$ \\
\hline TD3 & 47 min. 45 sek. & 34061 sp. ž. & $10 \mathrm{p}$. \\
\hline TD4 & 37 min. 27 sek. & 27239 sp. ž. & $7 \mathrm{p}$ \\
\hline TD5 & $49 \mathrm{~min}$. & 27433 sp. ž. & $8 \mathrm{p}$ \\
\hline TD6 & 1 val. 22 min. 25 sek. & 46567 sp. ž. & $12 \mathrm{p}$. \\
\hline TD7 & 56 min. 46 sek. & 33604 sp. ž. & $9 \mathrm{p}$. \\
\hline TD8 & 43 min. 39 sek. & 33647 sp. ž. & $9 \mathrm{p}$. \\
\hline TD9 & 47 min. 51 sek. & 28546 sp. ž. & $9 \mathrm{p}$. \\
\hline TD10 & 1 val. 49 min. 56 sek. & 51548 sp. ž. & $14 \mathrm{p}$. \\
\hline Iš viso & $567 \mathrm{~min}$. & 331374 sp. ž. & \\
\hline
\end{tabular}

Kokybinio tyrimo eigos etapai. Duomenys interviu būdu buvo renkami 2019 metų kovo - birželio mènesiais. Pokalbis su respondentais įrašytas diktofonu, visi įrašai transkribuoti.

Interviu tekstu transkripcija ir analizė atlikta 2019 metų birželio - rugpjūčio mènesiais. Kiekvieno tyrimo dalyvio duomenys analizuoti pasitelkiant induktyvumo nuostatą, kai tyrimas ankstesnis nei teorija, nes ,indukciniu požiūriu paremti natūralistiniai tyrimo metodai igalina praplèsti jau egzistuojančius teorinius požiūrius s"35. Koduojant duomenis koncentruotasi ị semantines temas, bet kreiptas demesys ir ì latentinę pokalbio raišką (emocijas, neverbalinę komunikaciją). Teminè analizė atlikta rekursyviai, t. y. grịžtant atgal per visą tyrimo procesą - renkant, koduojant ir analizuojant duomenis. Analizuojant duomenis, dokumentuotos tyrejo įžvalgos. Analizuojant surinktą interviu informaciją, susitelkta ị semantinị turinį, atsiribojant nuo žinomų teorinių modelių ar išankstinių nuostatų. Kiekvieno interviu analizė baigta parengta ataskaita ir sudarytu struktūriniu teminiu žemèlapiu.

Bendros teminès tyrimo ataskaitos formavimas, sujungiant visų tyrimo dalyvių duomenų ataskaitas ir teminius žemèlapius, vyko 2019 m. rugsẻjo - lapkričio ménesiais. Šiame etape iš naujo gilintasi į tyrimo duomenis, išskirtos esminès tyrimo temos, jos aprašytos, atskleisti temų tarpusavio ryšiai, rezultatai susieti su teorinèmis tyrimo nuostatomis, suformuluotos išvados. $2019 \mathrm{~m}$. gruodị - $2020 \mathrm{~m}$. vasarị vyko atlikto tyrimo ekspertinis vertinimas. Gauti dviejų ekspertų atsiliepimai. Atsižvelgiant $\mathfrak{i}$ jų kritines pastabas bei rekomendacijas, atliktos pataisos. $2020 \mathrm{~m}$. kovo ménesi straipsnis priimtas publikuoti.

\subsection{Empirinio tyrimo rezultatai}

Tyrimo rezultatai atskleidžiami pagal tyrime suformuotas penkias temas: 1) Svarbiausios veiklos bibliotekose; 2) Profesionalumo kaitos veiksniai, iššūkiai ir kliūtys; 3) Profesionaluma išreiškiančios kompetencijos; 4) Profesionalumo reikalavimai ir 5) Profesionalumo vystymas.

\subsubsection{Svarbiausios veiklos bibliotekose}

Tema Svarbiausios veiklos bibliotekose skirstoma ị keletą potemių: akcentuojamas bibliotekos tradiciniu veiklu puoselejimas, jų tęstinumas. Greta dèstoma apie siekius kurti inovatyvias biblioteku paslaugas ar praplèsti, papildyti jau esamas. Skiriamas dèmesys besikeičiančioms sqlygoms, kuriomis bibliotekos igyvendina veiklas.

Žydžiūnaitė, V.; Sabaliauskas, S. Kokybiniai tyrimai: principai ir metodai, p. 209. 
Tradiciju puoselèjimas. Tradicinès bibliotekų paslaugos yra svarbiausios, sudarančios bibliotekos institucinị išskirtinumą, jas reikia nuolat palaikyti, atnaujinti, pritaikyti prie nūdienos sąlygų. Pasak tyrimo dalyvio, svarbiausios veiklos bibliotekoje iš esmés nesikeičia, keičiasi tik šūkiai arba akcentai, kurios veiklos dabar nurodo naują (madingą) kryptị. „Kai tik pradejjau dirbti, labai modernu buvo sakyti: „Biblioteka kultūros centras." Paskui atsirado: „Biblioteka - informacijos centras.“ Paskui - bendruomenès centras. Šūkiai keičiasi, esmé pasilieka ta pati: biblioteka yra ta vieta $\langle\ldots\rangle$, kur gyvena bet kokia informacija, ir yra patikimas tarpininkas $\langle\ldots\rangle$, kuris $<\ldots .>$ padès susigaudyti, kas, kur, kada“ [TD7].

Pabrěžiama sisteminio požiūrio ir nuoseklaus darbo svarba. Būtina inicijuoti („užvesti“) ir tęsti darbą, profesionaliai taikant bibliotekininkų sukurtą sistemą, tam tikras taisykles, kad prireikus informaciją būtų lengva surasti ir ji būtų patikima. Sistema bütina išlaikyti, nors keičiasi priemonès, technologijos, žmonés. „Nes tai apjungia $\langle\ldots . .>$, kuo mes naudojamès šiandien, kai mums reikia į praeitị grižt <...>. Ir kad ateity gyvensiantys žmonès <...> galètų pasinaudoti tuo, ką mes šiandien kuriam“ [TD7].

Reikalingas veiklu balansas pasireiškia per siekius: 1) pritraukti naujų lankytojų ir 2) išlaikyti jau turimus skaitytojus (lankytojus). „Neužsidaryti nuo inovatyvių, naujų paslaugų <...>, o tradicines [veiklas] reikia išlaikyti, puoselèti“ [TD5].

Tradicinès viešųų bibliotekų veiklos skirtos prieigai prie informacijos suteikti. „Visos paslaugos yra svarbios. Tačiau, aišku, aš pati, kaip ir bibliotekininke būdama, ịsivaizduoju, kad [svarbiausia bibliotekoje] tai yra - užtikrinimas laisvos prieigos prie informacijos. Tai yra pati pagrindinè funkcija" [TD1]. Bibliotekos veiklos keičiasi, bet orientuojamasi ị tą patị žmonių lūkestį: ,jeigu noriu kažką sužinoti, tai kur galiu padaryti - pirmiausia bibliotekoje“ [TD3].

Tradicinių veiklų puoselejimas pirmiausia susijęs su skaitymo organizavimu. Svarbiausia veikla ịvardijamas komplektavimas, nes pirmiausias apsilankymo bibliotekoje tikslas - rasti norimą knygą. „Skaitytojas atejjęs visada nori rasti kuo daugiau naujų knygų $\langle\ldots$. , nes knygos yra brangios, [daugumai] neịperkamos" [TD4]. Dèl to, kad komplektavimas ne visada visiškai atitinka skaitytojų poreikius, bibliotekos imasi kitų veiklų, kad skaitytojai sugrịžtų ị biblioteką („,ne visada radę tinkamą literatūrą, kad jie iš mūsų nepabègtų, o sugrįžtų atgal. Todèl, be knygos, dar teikiam daug ịvairių paslaugų“ [TD4]).

Bibliotekos paskirtis - skaitymą skatinančios veiklos. Kita vertus, neužtenka, kad bibliotekoje būtų tik knygos. Būtina bibliotekose veiklą organizuoti ieškant tęstinumo, siūlant veiklą kitiems šeimos nariams: „atėję tèvai su vaikais, kad jie užsibūtu, <...> rastų kažką naujo, kas jiems patrauklu“ [TD2]. Skaitymo skatinimo plètra siejama su kultūriniais renginiais, mokymais ir edukacijomis, pasiremiant bibliotekos informacijos ištekliais ir turimomis technologijomis.

Skaitymą skatinančias veiklas bibliotekoje svarbiausia organizuoti taip, kad žmogus patirtu skaitymo nauda ( „Knygos, skaitymas yra labai svarbu $<\ldots>$. Nèra tokios organizacijos pasaulyje $<\ldots$. , kuri mokytu žmogų skaityt $<\ldots>$ ir kurti skaitymo naudą $<\ldots>$ aiškintų, teigtų $<\ldots>$ nuo mažens moko vaiką pratint prie knygos“ [TD10]). Šiame procese galima suderinti daug veiklų: „viskas yra suderinama $\langle\ldots\rangle$, kiek tai yra naudinga žmogui $<\ldots>$ visos veiklos svarbios, kurios padeda žmonių tobulejjimui, žmonių laimei, netgi“ [TD10].

Viena pagrindinių skaitymą skatinančių veiklų - kultūriniu ir mokomųju renginiu organizavimas. Keletas tyrimo dalyvių pažymi, kad renginių labai padaugèjo ir jie tapo įvairesni. Tyrimo dalyvio [TD9] nuomone, bibliotekos veiklų pagal svarbumą reitingas būtų toks: 1) edukacijos; 2) mokymai; 3) skaitymo organizavimo veiklos ir 4) renginiai. Kitas tyrimo dalyvis pabrèžia poreikị siekti aukštesnio (šviečiamojo) renginių lygio išlaikymo („Bibliotekoj vyksta ir joga, ir koncertas, nesusijęs ten su niekuo <...>, ịsileidžia abejotinos vertès lyderius <...>“. Tačiau: „Biblioteka vis tik turi išlaikyti tokị šviečiamajị lygị. Šiek tiek aukščiau kilstelèti“ [TD3]). Kitas pašnekovas pabrěžia bibliotekos poreikị išlikti lankstiems, taip pritraukiant daugiau lankytojų, tačiau tai kelia grèsmę pačios bibliotekos veiklų tapatumui: „bibliotekiné funkcija nukeliauja ị šešèlį“ [TD1], o susitelkiama ị kultūrinius renginius. Kitas tyrimo dalyvis mano, kad „renginiai tampa svarbia bibliotekos veiklos dalimi, tačiau tai yra priemonè <...>; būtina sisteminio požiūrio dalis“ [TD7]. 
Svarbi tradicinè viešųjų bibliotekų veikla - kraštotyra. Labai svarbu rajono bibliotekose „rasti, surasti, gebėti greitai atrasti visa tai, kaupti medžiagą, kas yra apie kraštą, jo istoriją, geografiją, žymius žmones ir visus kitus dalykus" [TD6]. Kitas tyrimo dalyvis akcentuoja šios veiklos prasmingumą, būtinybę jị tęsti: „Bibliografijos - informacijos, kraštotyrinė [veikla]. Kol kas ten dirba žmonès, turintys patirtị, mokantys išsirinkti, išsaugoti <...>. Norètųsi, kad tai išliktų" [TD2].

Inovacijos. Inovacijos viešųų bibliotekų veikloje pirmiausia siejamos su naujomis technologijomis. Pasak vienos tyrimo dalyvès, „prieš 20 metų būčiau sakiusi [pagrindinè veikla] - skaitymas. Dabar taip nemanau. $<\ldots>$. Dabar sakau: skaitymas, mokymas, naujų technologiju ịsisavinimas, informacijos paieška“ [TD3]. Turi būti atvirumas naujovèms, „mes turim ir nepamiršti, neatsilikti nuo gyvenimo ir turime neužsidaryti nuo tų inovatyvių, naujų paslaugų. Ir internetas, ir mokymai mūsų lankytojų, kaip naudotis kompiuteriu, skaitmeninėmis paslaugomis. Na, ir įvairios inovatyvios paslaugos mūsų lankytojams, kaip, pavyzdžiui, robotika“ [TD5]. Vienas tyrimo dalyvis teigia, kad iš ịpročio bibliotekininkai mano, jog „skaitytojų aptarnavimas $<\ldots>$ ar informacinè puse $<\ldots>$ yra svarbiausia. Tačiau $<\ldots>$ bibliotekininkui jau neužtenka vien šito". Ir nors vis atsirandančios naujos veiklos, šiuo metu - robotika, pasak pašnekovo, "galbūt ir gąsdina kai kuriuos <...>, labai jau iššǔkis yra paprogramuot", tenka apsiprasti - tai taip pat biblioteka [TD8]. Iki šiol tebèra akivaizdūs skirtumai, kaip darbuotojai suvokia pagrindines veiklas bibliotekoje: „vieni galvoja, $\mathrm{kad}<\ldots>$ leidinių išdavimas $<\ldots>$, na, dar kompiuterinio raštingumo kursai <...> visai pradedantiesiems. O kiti <...> apie multisensoriką, jos pritaikymą galvoja“ [TD8].

Inovacijos bibliotekų veikloje turi būti naudojamos reaguojant $\mathfrak{i}$ tai, kas aktualu bendruomenei. Pasak tyrimo dalyvio, „,bibliotekininkas turètų rasti veiklas per bendruomenei reikalingas programas $<\ldots .$. Žmonèms reikia $k a z ̌ k o ~<. .>$. Tikrai ne sienų bibliotekoje, kur rimta ten sẻdi moteriškè ir laukia, kol tu prieisi knygos pasiimt“ [TD8]. Šiuo metu svarbiausias interesas teikiant paslaugas yra „padèti žmogui $<\ldots>$ ísisavinti technologijas, kurios jam padetų gyventi“ [TD3]. Technologijos padeda ir pritraukti naujų vartotojų, ypač vaikų.

Pasak tyrimo dalyvio, „keičiasi laikmetis, priklausomai nuo to keičiasi ir svarbiausios veiklos <...>. [Renginių organizavimas] anksčiau buvo siauresnis $-<\ldots>$ tiesiog išsiplètė. Tai tapo papildomomis veiklomis prie skaitymo <...>. Jeigu nebus tų veiklų, sumažès ir skaitymas“ [TD9]. Didesnis lankytojų skaičius bibliotekoms svarbus kaip veiklos rodiklis, todèl bibliotekoje išskirtinai svarbi veikla yra kultūrinių renginių organizavimas [TD1]. Šioje tradicinejje veikloje taikoma daug inovacijų, tai ir naujos renginių formos, ịvairūs skaitytojų mokymai, tikslingas dalyvavimas projektuose.

Veiklų inovacijos pasireiškia ne tik diegiant naujas technologijas, bet ir susiejant tradicines paslaugas su naujomis, ieškant užsièmimų visai šeimai. Pavyzdžiui, „,ateina žmogus ị biblioteką pasiimti knygos [pasiteiraujama] gal jis norètų išmokti dirbt su kompiuteriu? - jam pasiūloma ịsirašyti ị kompiuterinio raštingumo kursus. [Pramokus pradinių kompiuterinio raštingumo elementų] jam pasiūloma igūdžius panaudoti, mokantis kalbų, bent susipažinti“ [TD2]. O jeigu ateina suaugę lankytojai su vaikais, kiekvienas gali rasti, ką veikti - suaugusieji gali savarankiškai, naudodamiesi kompiuterine įranga mokytis kalbų, vaikai - pabūti Šeimų erdvèje, „kur yra interaktyvios grindys, yra žaidimai visokie, loginiu mąstymu paremti, yra kino filmų peržiūra" [TD2].

„Biblioteka yra demokratiją palaikanti erdve < $<. .>$ kiekvienas kviečiamas ateiti ir turi rasti nišą savo veiklai“ [TD7]. Tai tikras iššūkis, reikalaujantis nemažai pastangų, nes „nebèra primestų <...> dalykų. $<\ldots>$ Dabar mes žiūrim $\langle\ldots$. , kad būtų ịdomu čia gyvenančiam žmogui ir atvykusiam turistui ar poilsiautojui. Tai yra didelis pliusas, ir tai yra nelengva“ [TD6].

Veiklų inovacijos apima didelị galimybių spektrą: „visos veiklos svarbios, kurios padeda žmonių tobulëjimui, žmonių laimei, netgi“ [TD10].

Keletas pašnekovų pabrèžia, kad inovacija bibliotekų veikloje yra projektinis darbas, pats projektų kūrimas, jų iggyvendinimas. „Svarbus yra ịvairių projektų rengimas $\langle\ldots\rangle$. Tai ne tik galimybė pristatyti skaitytojams naujas knygas, leidinius ar naujas paslaugas, bet tai yra galimybė būti matomiems, būti 
žinomiems, būti vertinamiems savo bendruomenèse, bet taip pat tai puiki galimybè atvesti $\mathfrak{i}$ biblioteką naujų lankytojų" [TD5]. Projektinis darbas tiesiogiai susijęs su nepakankamu finansavimu veikloms: „Rašom projektus, <...> ieškom įvairiausių būdų finansavimui gauti“ [TD1].

Sąlygos veikloms. Sąlygos, darančios ịtaką bibliotekų veikloms, - tai bibliotekų reikšmingumo suvokimas nūdienos kontekste, atnaujintas bibliotekų dizainas, profesionalūs darbuotojai, toje pačioje vietoveje veikiančiu skirtingo pavaldumo bibliotekų bendradarbiavimas ir su kitomis institucijomis, nepakankamas finansavimas, konkurencija dèl tų pačių vietovès gyventojų (paslaugų klientų) ir dèl to kylantis paslaugų dubliavimas.

Pasak tyrimo dalyvio, nuo aplinkos sąlygų priklauso, kiek biblioteka yra naudinga žmonėms ir kaip žmonès suvokia bei patiria jos teikiamą naudą. Geriausiai bibliotekos veiklų svarba atskleidžiama lyginant. Dalyvis pateikia pavyzdžius iš asmeninès netrumpos (daugiau kaip 20 metų) darbo bibliotekoje patirties: sovietmečiu „jeigu ateidavo koks vienas žmogus į bibliografinị skyrių per savaitę, tai jị laikẻ nesveiku. Ko jis čia atėjo <...>, mes visi turim knygų namuose ir kam eit ị biblioteką? Turbūt kažkoks nevykèlis, keistuolis" [TD10]. Paskui atejjo toks laikas, kai bibliografijos skyrius buvo perpildytas, dešimties vietų skaitykloje tilpdavo ir 15, ir 20 lankytojų. „Nes visiems reikèjo susigrąžint žemes, kažkoki turtą, prisiteist kažkokią žalą - už tremtị, už dar kažką. <...> [Paskui atėjo metas, kai] vieniems [biblioteka] buvo kažkokia pinigus siurbianti ịstaiga $<\ldots>$, kiti romantiškai kalbẻjo, kad Aleksandrijos biblioteka išliko ir dabar bibliotekos išliks. <...> Dažniausiai tai kalbejjo nedirbantys bibliotekose, o mes stengèmès $<\ldots>$ išsilaikyti, kažkaip parodyti, kad mes nesam pinigu siurbliai“ [TD10].

Aplinkinių suvokimas apie bibliotekos veiklų svarbą labai priklauso nuo bibliotekos pastato ir visos aplinkos atsinaujinimo. „<...> kada buvo patvirtinta $<\ldots>$ bibliotekų modernizavimo programa, tai iš tikrųjų pakito iš esmès. Ir mūsų pastatai, ir mūsų interjerai, ir visi kiti dalykai. Tai yra labai svarbu" [TD10]. Kita vertus, išskirtinai svarbu, koks personalas dirba bibliotekoje. To paties pašnekovo žodžiais: „ta opinija apie biblioteką < ... [Bibliotekoje] gražu. Bet... o kas tave pasitinka? Ir kaip sutinka? tai yra supersvarbu“" [TD10].

Bibliotekų veikloms ịtaką daro gebèjimai bendradarbiauti. Aptardamas apskričių bibliotekų pagrindines veiklas, pašnekovas išskiria ị regioną nukreiptas veiklas (su kitomis vietoveje veikiančiomis institucijomis) ir bendras veiklas su regiono bibliotekomis. Pasak pašnekovo, veikla su regiono bibliotekomis turi būti grịsta bendradarbiavimu, o ne nurodymais. Apskričiu bibliotekos bendras veiklas gali kuruoti, moderuoti, kartais - kartu atlikti bendrus projektus, veiklas regione („Važinėjam po regioną su ịvairiu spektru bendrų veiklų, kartais ir paslaugų i̇vairių. Pavyzdžiui, turim programą <...> žmonėms su negalia“ [TD4]).

Tyrimo dalyvio žodžiais, „[labai svarbu] tas komunikavimas su kitom įstaigom, organizacijom. Ir kartu su personalijom, kurie ir čia ateina, ir kurių pats ieškai. Yra labai svarbu bibliotekai, kad jinai būtų gyva ir patraukli“ [TD6]. Kita vertus, panašaus profilio institucijos toje pačioje vietovejje konkuruoja dèl tų pačių lankytojų (vietos gyventojų), todèl stengiasi pasirodyti kuo geriau („Jau neduosi kažkokių ten paprastų paslaugų. Nes $<\ldots>$ [yra keletas stiprių] žaidejjų, kaip mes $<\ldots>$ kultūros lauke. $<\ldots>$ Ir tarp viso ko, jeigu mes norim išlikti, kaip lygiavertis, nu, panašaus prašmatnumo ịstaiga, sakykim $\langle\ldots\rangle-$ mes irgi turim atitinkamai kažką daryti. Ir netgi, sakykime, viešai... išoriškai patraukliais pavidalais. Kad žmogus <...> sakytų: „O! Čia va taip biblioteka padarè!“ [TD6]).

Kita vertus, nedidelèse bendruomenėse tai kelia paslaugų dubliavimo problemą. Pasak pašnekovo, „kaimuose yra bendruomenès centras, biblioteka ir kultūros skyrius. Ką tokio jos visos gali pasiūlyti 200 gyventojų? Ir visos turi daryti atskirai, kad pateisintų savo egzistenciją “ [TD1]. Kitas tyrimo dalyvis šioje situacijoje mato poreikį bibliotekoms kurti ir pasitvirtinti savo tapatumą. Pasak jo, plečiant veiklas, susiduriama su panašių paslaugų dubliavimu, o tai kelia tapatumo išnykimo grèsmę: „pedagogų daug be darbo, jie sukūrè visokius švietimo centrus, jie irgi neformaliai šviečia“ [TD3]. Tai ne vien skatina sveiką konkurenciją, bet ir inspiruoja bibliotekas apsibrèžti savo veiklos kryptị „kryptị nusibrèšim, kas yra ta biblioteka. Dabar biblioteka yra viskas, o paskui bus - niekas. Ant veteranų laikosi ta kryptis“ [TD3]. 
Bibliotekos finansuojamos valstybès lèšomis, tačiau lèšų papildomoms veikloms paprastai neužtenka. Todèl daugumą lèšu veikloms paįvairinti, papildomoms paslaugoms bibliotekos užsidirba, rengdamos projektus. Pasak tyrimo dalyvio: „kultūriniams renginiams vesti reikia gauti finansavimą, kitaip jị i̇domiai pravesti labai sunku. Ir užsidirbti mums reikia pinigų. Mes viską [uždirbame] iš projektų“ [TD1]. Kitas dalyvis argumentuoja: „be papildomo finansavimo, tik iš savivaldybès, tai mes būtume niekas“ [TD3].

\subsubsection{Profesionalumo kaitos veiksniai, iššūkiai ir kliūtys}

Tema Profesionalumo kaitos veiksniai, iššūkiai ir kliūtys suskirstyta ị keletą potemių: kaita įtakojantys veiksniai, kurioje nusakomas besikeičiančios aplinkos daromas spaudimas keistis ir pokyčius lemiančios sąlygos; pokyčiu kelyje patiriami iššūkiai, kuriuos kai kurios bibliotekos sprendžia, ir nusakomos kliūtys, sutinkamos permainų kelyje ir suvokiamos kaip problemos, kurioms reikia ieškoti sprendimų.

Kaita lemiantys veiksniai. Apmąstydami transformacijas lemiančius veiksnius, tyrimo dalyviai kalba apie aplinkoje vykstančiu pokyčiu lemiama spaudima keistis. Keičiantis politinei sistemai, nuolat kintant technologijoms, biblioteka ir joje dirbantis personalas privalo keistis: „Mes norejom ar nenorejom, visi turèjom pasikeist <...>. Nes pasikeitè biblioteka“ [TD2]. Ir todèl „būti reikalingu žmonèms, tai tu turi būti profesionalu, tik taip nugalèt gali viską“ [TD3]. „Vyksta transformacija, nesakau - tobulejimas. Prisiderinimas prie realaus gyvenimo" [TD1]. „Jei bibliotekininkas sèdès ir sakys: „, $<. .>$ ne $<\ldots>$, kompiuteris yra negerai, tai užsidarys vieną dieną ta įstaiga. Ir labai greit ta diena ištiks" [TD3]. Iššǔkius profesionalumui kelia pati besikeičianti aplinka, Pasak tyrimo dalyvio: „Ir skaitytojas pakito, ir bibliotekininkas. Yra skaitytojų $\langle\ldots$. , kurie ateina ir išeina su bibliotekininku ne nepasilabinę. Pasikeičia knygas savarankiškai ir viską atlieka savarankiškai. Todèl pas mus yra atviri fondai“ [TD4]. O kiti ateina pasikalbèti, pabendrauti - bibliotekininkas ir tam turi būti pasiruošęs. Mokèti kalbas tampa būtina skaitytojus aptarnaujančių darbuotojų kompetencija, nes „ypač interneto skaitykloje ateina skaitytojai iš Azijos, Afrikos, iš Europos, iš Amerikos, iš Japonijos, iš kur nori“ [TD4]. „Kad ateitų žmonių [ị biblioteką], tai paslaugos turi būti labai geros" [TD3].

Profesionalumą skatinantys veiksniai, tyrimo dalyvio nuomone, yra darbuotojų noras pagelbeti kitiems, būti ịvertintiems, pasididžiavimas savo institucija („Tu didžiuojiesi savo įstaiga, ko anksčiau bibliotekose nebuvo" [TD3]). Skatinama nebūtinai pinigine išraiška, bet ir darbuotojus viešai pagiriant, apdovanojant („I kokị seminarą išsiųst, < _..> viešai pagirt, apdovanot - tai irgi labai žmogui svarbu. Motyvuot labai svarbu darbuotojus" [TD3]).

Kita vertus, vienas iš pokyčius lemiančių veiksnių tebėra tas, kad bibliotekininko profesijoje vis dar gajūs "ramaus darbo“ lūkesčiai: „liūdna, bet vis dèlto ateina žmonès, kurie dažniausiai tikisi ramiai būti“ [TD8]. Pasak pašnekovo, „pasirinkę specialybę pagal kriterijų „ramus darbas dèlioti knygas“, dabar piktinasi, kad „yra verčiami daryti kažką daugiau“. Tuo pagrindu tyrimo dalyvis samprotauja "gal specialybè visą laiką buvo suprantama per siaurai <...> - tas knygų dèliojimas“ [TD2].

Bibliotekininko profesiją dažniausiai renkasi turintys polinkị i humanitarinius mokslus, ypač tai būdinga vyresnès kartos atstovams. Pasak tyrimo dalyvių: „dauguma bibliotekininkų yra humanitarai“ [TD5]. Su tuo susijusi technologiju įvaldymo baimè ir pasipriešinimas tam („Man, kaip ir kolektyvui, tai yra visiškai neįdomu tas programavimas“; „Tų laidukų ten begalè, jų junginejjimas... ir galų gale... aš visiškai to... na, aš esu labiau literatūros žmogus“; „Susėdom vos ne visas kolektyvas su fizikos mokytoju $<\ldots>$. Visų akyse daug išgąsčio“ [TD5]). Kitas tyrimo dalyvis sako: „Tas naujumas <...> jis sukelia galbūt šoką, bet tu turi paskui pats gilintis - ieškoti, skaityti, domètis“ [TD2].

Didelę ịtaką profesionalumo pokyčiams turi bibliotekų vadovai, pasirinkdami naujoviu pritaikymo kolektyve būdus. Tyrimo dalyviai dalijasi patirtimi: „pati vedžiau už rankos <...> kolektyvą, ir dabar jau pakankamai žino <...>“ [TD10]. „Pokyčiai, kokie vykdavo, mes visą laiką susitarèm. <...> be audrų stiklinèje. $<\ldots>$ Kiekvienas žmogus turi būti savo vietoje“ [TD7]. Kolektyve skatinamas pozityvus nusiteikimas: „Daug kalbèjau, kad nereikia forsuoti, igūdžius igysim per laiką“ [TD5]. 
Svarbus pokyčiu veiksnys yra profesijos lyderiai, autoritetingi žmonès, kurie ịkvepia, nukreipia keistis. „Tie nauji dalykai į biblioteką atėjo su žmonèmis, tai Audronė Glosienė, Ramunė Petuchovaitė..." [TD2]. „Lyderio balsas yra labai svarbu <...> kokia buvo profesore Glosiené“ [TD3].

Didysis lūžis ịvyko dèl tarptautinių didžiųjų projektų suteiktų galimybių. Buvo mokomasi ne tik dalykinių, bet ir bendrųjų kompetencijų: „mokemès psichologijos, paslaugų, komunikacijos, projektų rengimo ir visa kita, ir visa kita“; „Ir daugelis, net patys to nejausdami, kvalifikaciją pakèlè iki tokio lygmens, kad šiandien $<\ldots . .>$, sakykim, negèda " [TD4].

Svarbus profesionalumo kaitos veiksnys yra pinigai, personalo atlyginimai, jų skirtumas, palyginti su kitomis institucijomis, taip pat institucijų veiklos finansavimas. Tyrimo dalyvis teigia: „prireikè daug metų, kol mes po truputị, po truputi išjudinom tą visą sistemą. Kad pamažu pradètų kilt atlyginimai. Tai buvo tragiškai sunkus darbas" [TD4]. 1996-1997 metais, pašnekovui pradejjus dirbti bibliotekoje, jo atlyginimas buvo 400 litų. Pasak pašnekovo, toks atlyginimas neskatina profesionalumo („Kiek mokejo, už tiek ir dirbo“; „Buvo, žinot, labai blankus vaizdas, ir reikalavimai buvo neaukšti. Dabar bibliotekininkas gauna, sakykim, 600 ar 800 eurų, tai litais, jei padaugint iš 3,5, tai... Na, suprantama, čia keitėsi pinigai, bet vis tiek... Nepalyginsi, kas buvo" [TD4]).

Profesionalaus darbo bibliotekose neskatino ir valstybès finansavimo esminėms bibliotekos funkcijoms nestabilumas. Pasak tyrimo dalyvio, „2009 metams buvo numatyta 7 milijonai litų <...> leidinių ísigijimui. Ir tai buvo didelis šuolis ị priekị, nes <...> kiekvienam gyventojui po 2,5 lito ir tais laikais tai buvo labai geros lěšos. Ir kas atsitiko? Tais metais buvo nubraukta 5 milijonai litų ir knygų ịsigijimui liko tik 2 milijonai <...>. Ir nuo to laiko iki dabar, tik 2019 metais pagaliau pasiektas ikikrizinis lygis. Tai praktiškai buvo prarasti ištisi [dokumentu]] fondai, ištisi“ [TD4]. Kitas tyrimo dalyvis nepakankamu finansavimu ir darbo bibliotekoje specifika argumentuoja negalèjimą pritraukti naujų, kūrybingų asmenybių darbui bibliotekoje: „turèjom galimybę pakviesti [aukštos kvalifikacijos, gerbiamą žmogų] $<\ldots>$ deja, mūsų darbo grafikas tai yra toks, koks yra. Tai ir savaitgaliai, ir kintami ir t. t., ir atlyginimas, švelniai tariant, kuklokas, kaip kitose institucijose. <...> Mes pralaimim. Pralaimim pirmiausia dèl mūsų, apskritai dèl sektoriaus pinigų“ [TD7].

Tyrimo dalyvis pamini atveji, kai bibliotekoje įsidarbino iš banko išèjusi mergina. Pasak pašnekovo, ji tokị sprendimą motyvavo pavargimu nuo verslo ir noru realizuoti save. ,Ji atsigavo per pusmetį. Isisuko ị ịvairius projektus ir pradejo nebetilpt rèmuose <...>. Dabar ji vèl išèjo. Kad sugrịžtų [ị banką], jai siūlo penkeriopai ar dešimteriopai didesnị atlyginimą, ir vèl ji išeina " [TD4]. Pašnekovo teigimu, dirbti bibliotekoje merginai patiko, ji turẻjo daug papildomų veiklų, edukacijų, projektų idejų̨. Tačiau vienas didžiausių iššūkių - maži atlyginimai, dẻl kurių dažniausiai jauni žmonès palieka biblioteką. Kitas tyrimo dalyvis kalba apie sunkumus susirandant darbuotoją rajono filialuose: „netoli miesto kvalifikuoti žmonès nenori dirbt už mažą atlyginimą“; , ,ateina toji karta, kuri nesutinka <...> gauti mažiausią atlyginimą. <...> jie turi užsidirbti“ [TD9]. Kaip teigia kitas tyrimo dalyvis, kol ekonomine situacija tokia, kad bibliotekininkų atlyginimai neužtikrina oraus žmogaus fiziologinių ir saugumo poreikių, jis negali atsipalaiduoti ir tapti kūrybingas („pirmiausia turi būti tie pagrindiniai poreikiai patenkinti, kad žmogus būtų ramus dèl <...> savo kasdienio gyvenimo“ [TD10]).

Iššūkiai pokyčių kelyje. Aptardami iššūkius, su kuriais susiduria bibliotekos dèl kintančių profesionalumo sampratų, pašnekovai kalba apie nauju technologiju įvaldyma, skirtingu kartu (generaciju) vertingumo pokyčius, vadovams kylančius iššūkius atskleisti turimus darbuotojus, ị bibliotekas ateinančius dirbti nespecialistus, igūdžiu stoka, pasireiškiančia plečiantis bibliotekos veikloms, rinkodaros principu taikymo iššūkius, sunkumus keičiant savivaldos ir aplinkos požiūrį į biblioteku vertinguma, ǐšūü bibliotekoms išlaikyti turima patraukluma ir likti reikalingoms bendruomenems. Šie iššūkiai bibliotekininkų yra pripažinti ir pradèti spręsti.

Vienas didžiausių iššūkių, kurị bibliotekoms tenka spręsti, yra susijęs su naujųjų technologijų ịvaldymu. Tai „laikas, kai mes iš <...> bibliotekos vien su knygomis, staiga iššokom i technologijas“ [TD2]; tie 
„Žaibiški technologijų pokyčiai“ [TD7]. „Naujos informacinio ir technologinio raštingumo kompetencijos pradètos vystyti ir jau įdiegtos nuo projekto „Bibliotekos pažangai“ laikų. „Tuomet ịteigè, kad jie tokie privalo būti“ [TD8]. Išskirtinai svarbu suteikti pagalbą prisitaikant prie kintančių sąlygų, pavyzdžiui, bibliotekoje įdarbinti IT specialistus, kurie galètų konsultuoti darbuotojus („Dabar turim tris IT specialistus, ir prie jų - bibliotekininkai. Tai vat tada jie gali dirbt“ [TD3]). Susidūrus su problema, tampa aktualūs jos sprendimo būdai. Pokalbio dalyvis mini sunkumus: vadovai darbuotojus ramina, nuteikia pokyčiu etapams, o visai kito poveikio sulaukiama iš kai kurių edukatorių (numatytų projektuose, pagal kuriuos biblioteka aprūpinama naujais įrenginiais ir technologijomis). „Atveža robotikos rinkinius, kur metodikoje įrašyta, kad 1,5 val. truks pristatymas. Paskambino į biblioteką prieš $10 \mathrm{~min}$. [iki atvykimo] ir užtrunka 20 min. <...>. Ką tikrai ịsiminèm, tai „Jūs čia neišmanot, samdykit mane. Aš atvažiuosiu ir viską pravesiu. $\mathrm{O}$ iš jūsų tai čia tikrai nieko nebus". <...> Iš pradžių buvo nedrąsu, bet po truputị, po truputị... $<\ldots>$ Atsirado savanoriu, radom su kuo galim bendradarbiauti..." [TD5].

Iššūkius dèl pasikeitusiu veiklu, grindžiamu IT naudojimu, kai kurios bibliotekos sprendžia be didelių problemų, perkvalifikuodamos šia sritimi besidominčius entuziastus. Pasak tyrimo dalyvio, „nèra [bibliotekoje] baigusių informacinių technologijų studijas. Igijo tų žinių [per mokymus, projektuose] ir dabar gali vest neformaliojo švietimo veiklas. Bibliotekos informacijos procesų inžinierius yra nebaigęs [IT studijų], bet dirba ir puikiausiai susigaudo" [TD10]. Kita vertus, trikdo intensyvūs šalies mastu inicijuojami pokyčiai, keliantys daug streso (pavyzdžiui, nepasiruošus vykdomas buhalterijos centralizavimas), kai kolektyvas gyvena baimèje, ar iš viso gaus atlyginimą ir galès įvykdyti kasdienius ịsipareigojimus (mokesčiai ir pan.). Situacijoje gelbejjo tik pačios direktorès turèti informacinių technologiju ir kiti igūdžiai.

Nauji iššūkiai, kuriuos tenka spręsti bibliotekininkams, - kartų (generaciju) vertingumo pokyčiai. Vienas pašnekovas sako: „turintis patirtị, dirbantis bibliotekoje, jeigu jis sugeba prisiderinti, yra gerai. Kai jaunimas su patirtim sutinka, tai labai daug gerų dalykų [galima padaryt] “ [TD2]. Tačiau tai nèra ịprasta, kad ilgą patirtị turintys darbuotojai turi mokytis iš jaunų, ką tik atejjusių dirbti darbuotojų. „Ir mes sakom $<\ldots>$ seniai dirbančioms [filialų darbuotojoms]: „reikia pasimokyti iš jaunos savo kolegès būti matomai, kaip dirbti su bendruomene, kaip biblioteką padaryti reikalinga bendruomenei“ [TD5]. Pagrindine priešpriešos tarp jaunesnio ir vyresnio kolektyvo priežastis: vyresniems trūksta motyvacijos nugalèti savo vidinę baimę, juk „patogu [nieko nedaryti]. Tada nereikès galvoti, aš neturèsiu jaudintis“ [TD1].

Tyrimo dalyvis pabrèžia tarp skirtingu kartu atsiradusius prieštaravimus, kaip yra suvokiama skaitymo svarba. Pasak pašnekovo, „keturiasdešimtmečiai ir vyresni <...> auginti toj aplinkoj, kad skaityti ir nenuobodu ir madinga $<\ldots .$. . Ateina karta, kuriai tie dalykai visiškai nesvarbūs. Arba mažiau svarbūs" [TD7], ir biblioteka turi reaguoti ị tai ir keisti veiklą. Vis daugiau tenka dirbti su socialiai jautriomis grupėmis, kartu iškyla ir nauji iššūkiai: „nebuvom mokomi dirbti su specialiųjų poreikių turinčiais žmonèmis. Su tikslinèmis grupèmis“ [TD10].

Plečiantis bibliotekų veikloms, vadovams svarbu atskleisti darbuotoją, rasti jam tinkamą darbo vietą. Jei vienam nesiseka ten, jam ieškoma kitos vietos. „Bibliotekoje reikia visokių <...>. Ir tikrai čia labai skirtingos kompetencijos gali praversti. Tik labai svarbu, ar žmogus savo vietoj, ar ne savo“ [TD7]. „Vadovas turi atsirinkti iš tos žmonių gausos, kad būtų žmogui įdomu dirbt bibliotekoj“ [TD2]. Tenka ieškoti kitos srities profesionalų arba tinkamai ị pareigas parinkti jau dirbantị bibliotekoje asmenị. Taip, pavyzdžiui, Komiksų centre dirba gebejjimų piešti turintis, su daile susijęs asmuo, o kalbų programas kuruoja anksčiau dirbusi bibliotekoje darbuotoja, turinti anglų kalbos išsilavinimą.

Iššǔkis profesionalumui yra tai, kad naujai įdarbinami bibliotekininkai dažnai nèra šios srities specialistai, jie nebaigę bibliotekiniu studijų. Bibliotekose, kuriose susiduriama su kvalifikuotų darbuotojų trūkumu, kritiškai atsiliepiama apie įsidarbinančius jaunus žmones: „Jam trūksta bibliotekininko kompetencijų? Ne, jis jau iškart pareiškia, kad jis turi“ [TD9]. Todèl jau priimti ị darbą jie turi nuolat mokytis ir bendrųjų, ir specifinių profesijos dalykų. Ateinantys dirbti jauni žmonės yra reiklesni ir nenusiteikę 
ilgai laukti pagerejjimo („padirbo - netiko - išeina. Be jokio supratimo, kad <...> i tave ịdèta daug darbo $<\ldots>$, mokymai praeiti, dètos viltys. $<\ldots .>$ apsisuka ir išeina" [TD9]).

Kitas tyrimo dalyvis akcentuoja, kad nespecialistus adaptuoti darbui užima laiko („Tikrų bibliotekininkų mes jau nebegaunam <...>. Ateina filologai, pedagogai, ekonomistai“ [TD3]). Pasak pašnekovo, jie tampa gerais darbuotojais, bet „tenka labai ilgai aiškinti, kas yra biblioteka“ [TD3].

Iššükis profesionalumui yra trūkstamos kompetencijos atlikti išsiplètusias, anksčiau nebüdingas veiklas bibliotekose. Tai pedagoginès, kultūrinių renginių vadybininko, darbo su tikslinėmis grupėmis kompetencijos. „Dabar reikia parodyti, pademonstruoti, daugiau pabendrauti. Išsigąsta“ [TD1]. „Kultūrinių renginių organizavime stiprus turi būti bibliotekininkas. Kūrybines dirbtuves ten kažkokias suorganizuot <...> būti mediatorium, tai yra ne pats jisai mokina ten dekupažo $<\ldots . .>$, bet suranda ką, kas parodys" [TD8].

Šiuo atveju iššūkiu tampa ir tapusios labai svarbios asmeninès darbuotoju savybès, tokios kaip lankstumas, atsakomybè ir pan. („Privalai programoje dalyvauti, lěšu numeta trupinèlĭ, ir tada tu turi suktis“ $<\ldots . .>$. „Biblioteka tampa ir socialinè įstaiga <...>. Turi mokèti atsiriboti, nukreipti tinkama linkme žmogų“ [TD1]). Profesionalumo iššūkis yra kiekvienam bibliotekininkui būti atsakingam už tai, „kaip visa biblioteka veikia. <...> Anksčiau [buvo] atėjo žmogus - neatèjo - nu, ką padarysi..." [TD1].

Iššǔkiu tampa kompetenciju ugdymas ar ju tobulinimas. Pasak tyrimo dalyvio, „daugelis bibliotekoje nori kelti kvalifikaciją, nežiūrint ị amžių“ [TD2]. O dar visai neseniai „buvo toks laikas: „O kam man reikia <...> ... Nenorèdavo“ [TD2]. Vis dar yra darbuotojų, kurie nèra linkę tobulèti: „Visko galima išmokt $\langle\ldots\rangle$, bet yra ir kas nemoka $<\ldots$. . Toks užsispyrimas $<\ldots>$ tikrai pakenkè bibliotekai“ [TD10]. Kitas tyrimo dalyvis pabrèžia, kad mokymai turi būti ne iš projektinio finansavimo („Man atrodo, kvalifikacijos kèlimas $\langle\ldots\rangle$ [kaip] projektinè veikla - tai nenormalu. Turi būti biudžete numatyti pinigai kvalifikacijos kèlimui $\langle\ldots\rangle$, vykti pagal iš anksto parengtą sistemą, kad būtų galima gauti norimų aktualių temų ir pasikonsultuoti $<\ldots . .>$, kas neaišku" [TD5]).

Kai kurios bibliotekos taiko netradicinius kompetencijų tobulinimo būdus, pavyzdžiui, savanoriu darbo organizavimą: „[savanoriai] labai ịneša <...> gaivumo ị kolektyvą. Ir patempia iš paskos kitus darbuotojus" [TD3]. Kitas dalyvis antrina: „atvykstantys savanoriai - tai iššūkis, kuris skatina personalą tobulèti, kitaip pažvelgti į daugelị dalykų („Reikia mokèti kalbas. <...>. Nes tai jauni žmonès, juos reikia ịvest ị mūsų gyvenimą <...>. Čia svarbu turèti tolerancijos, komunikavimo gebejimų “ [TD6]).

Gana naujas iššūkis bibliotekoms yra rinkodaros taikymas. Bibliotekininkai skatinami pakviesti žmones į biblioteką, pasiūlyti jiems naujas veiklas, parengti projektus ir pritaikyti veiklas tam, ko nori bendruomenè. Pavyzdžiui, „[sukurtas] projektas, kurio esmé <...> atėjęs ị biblioteką bet kokio amžiaus žmogus, ar tai būtų senelis su anūkais, ar tèvai su vaikais - kad visi jie rastų, ką veikti“ [TD2]. Kitas tyrimo dalyvis mano, kad iššūkis darbuotojams yra gebejjimai atlikti rinkodaros tyrimus („surinkti ir analizuoti duomenis <...> ir pagal juos planuoti veiklą" [TD8]). O iššūkis administracijai - panaikinti biblioteku tinklo veiklos netolygumą. Pasak pašnekovo, „reikètų, kad kuo daugiau [veiklų] atsirastų tuose nutolusiuose rajonuose nuo centro [filialuose]. Kur tos bibliotekos būtų daugiau tarsi pateisinančios savo buvimą <...>. Tai ir susiveda ị dirbančiųjų profesionalumą" [TD8].

Rinkodaros principu dalimi bibliotekoje pasireiškia lankytojų demesio pritraukimas per išorini patrauklumą („,išorinio patrauklumo, išorinio kablio dabar reikia visai visuomenei“ [TD7]). Tai pasireiškia ir per patrauklaus pastato, vidaus erdvių dizaino reikšmingumą, bet kartu ir per poreikị teikti ne visada kokybišką (bibliotekininkų požiūriu) turinị. Pasak pašnekovo, „su skaudama širdimi mes turim komunikuoti tokias žinutes, kurios mums patiems gal ir nelabai įdomios, bet jos domina publiką" [TD7].

Iššūkiu dviem iš dešimties tyrimo dalyvių yra siekis keisti savivaldos požiūrị i pačią instituciją ir bibliotekininkų darbą. Pašnekovo teigimu, kaip galima keisti bibliotekos savininko teises ir pareigas igyvendinančios institucijos požiūrị i bibliotekos veiklą ir jos vertingumą, reikètų pasimokyti iš bibliotekininkès Amerikos provincijoje (pagal Diujis: katinas, apvertęs pasauli aukštyn kojom. / Vicky Myron ir Brett Witter - Vilnius: Alma littera, 2009). Biblioteka turi įrodyti savo svarbą bendruomenei. Tyri- 
mo dalyvè dalijasi savo patirtimi, kai teko įveikti dvipusị pasipriešinimą - iš aplinkos, „kur nuolat kalè: „Kas ta biblioteka? Kam jos reikia?“ [TD10], ir iš kitos (darbuotojų) pusès: „nesugebi parodyti ir perkalbèt valdžios“ [TD10]. Vadovas turi nuolat įrodinèti: „nepramuši kakta sienos, bet eini, ieškai, bandai. Svarbūs yra geri santykiai, kitą kartą - mokèjimas nusileisti $\langle\ldots$.$\rangle , kitą kartą - svarbus pastovèjimas už$ save“ [TD10]. Didžiausi iššǔkiai išsprendžiami asmeniniu pavyzdžiu („negaliu dirbt puse kojos. Ir noriu iš savo kolektyvo to " [TD10]). Pasak kito tyrimo dalyvio, akivaizdūs iššūkiai, kuriuos sprendžia biblioteka - darbuotojų profesionalumo ir bibliotekos aplinkos svarbos, organizuojant veiklą, suvokimas, darbuotojas turi būti lankstus aptarnaudamas bendruomenę ir turi pozityviai keistis bibliotekos dizainas, aplinka, kurioje lankosi bendruomenè. Pašnekovès sako, kad „reikia siekti to profesinio prestižo, ieškot ìvairiausių būdų" [TD9].

Iššūkis išlikti patrauklioms, reikalingoms. „Pagrindinis dalykas <...> šiuo laiku - išgyventi ir kažką daryti, kad biblioteka nebūtų uždaryta“ [TD9]. Pasak kito tyrimo dalyvio, bibliotekoje „<...> bus pokyčiai. Pastovūs pokyčiai $<\ldots>$ neturim teisès atsilikti. Nes kitaip tai... išnyksim $<\ldots>$. [Bibliotekos turi išlikti] patrauklios, žavios ir reikalingos visuomenei <...>. Bibliotekoje turi virti gyvybė... ir kad ta gyvybė virtų, turi dirbti kvalifikuoti žmonès. Ir žmonès, kurie norètų tą daryti“ [TD6]. Kita tyrimo dalyvè sako, kad spręsdami iššūkius bibliotekininkai turi „turèti sveiko proto“ [TD3]. Pavyzdžiui, siekdami parengti kokybišką renginį, bibliotekininkai ieško finansavimo, kad sumokètų dalyviams, o patiems bibliotekininkams už profesionalų mokymų turinio ar renginio parengimą niekas nemoka („Ieškom ịvairiausių būdų finansavimui gauti, kad pritrauktume lektorius, nes bibliotekininkas ir už dyką gerai dirba, kam jam duoti“ [TD3]).

Iššǔkis bibliotekoms, pasak tyrimo dalyvès, yra gebejjimai suvokti, kad „turi eiti šalia ir materialinè bazè, naujosios technologijos ir specialistas. Ir tada vartotojas bus patenkintas" [TD6]. Nes šiuo metu „gaunasi paradoksas. Jeigu mes iš materialinès pusès, tarkim, padarèm žavias bibliotekas $<\ldots\rangle$. Iranga patraukli $\langle\ldots\rangle$, nauji kompiuteriai ir visa kita. $\mathrm{O}\langle\ldots\rangle$ su bibliotekininku pačiu $<\ldots$. , kaip su specialybe tokia... jos, kaip ir nèra. Jos kaip ir nereikia? Ne, mes tikrai su tuo negalim sutikti, reikia šią problemą spręsti. Siekti, kad profesionalūs bibliotekininkai išliktų“ [TD6].

Patiriamos kliūtys. Tyrimo dalyviai kalba apie tokias profesionalumo kliūtis: asmeniniai darbuotojų psichologiniai barjerai (konservatyvumas, pasipriešinimas naujovèms), nepakankamos motyvavimo priemonès siekti profesionalumo, mokymų naujiems įgūdžiams ịgyti ir kvalifikuotų specialistų trūkumas, bendros bibliotekų politikos stoka ir negebejimas parodyti savo atliekamų veiklų vertingumo. Tai problemos, su kuriomis susiduria tyrimo dalyviai.

Keletas kalbintų tyrimo dalyvių, svarstydami apie profesionalumo kliūtis, ịvardijo konservatyvuma, pasipriešinima naujovems, kuris dažniausiai pasireiškia ilgai dirbantiems bibliotekininkams. Pasak vieno tyrimo dalyvio, „milžiniškas barjeras naujovėms“ [TD1]. „Labai daug yra tokios inercijos, tokios klaikios... tegul ten jauni... kažkokie teoriniai, kažkaip kitaip padarys“ [TD8]. Tas pasipriešinimas reiškiasi tuo, kad ,jie nenori to [kažko naujo] daryti, o jeigu priverčiami - daro atmestinai“ [TD10]. Tebèra įsitikinusių, „kad biblioteka - ne renginių klubas. Išduoda knygas ir užtenka“ [TD10]. Taip ir išeina, kad iškreipiami veiklos prioritetai, pavyzdžiui, „labai karštai reaguoja, kad skaitytojai knygų negrąžino <...>, seklių biurai įsiveisę yra <...>. Čia neturètų būt pagrindinis rūpestis bibliotekininko" [TD8]. Viena iš kliūčių - lètai vykstantis personalo atsinaujinimas: „jauni negali ateiti, atvirai sakant, nes kartais dirba ir labai ilgai žmonès. Ir jie viską jau žino. To amžiaus, kur jau nieko nepakeisi... jo nuomonès“ [TD8]. Sudètinga situacija yra su baigusiais profesijos studijas ir tai suvokiančiais kaip pakankama profesionalumo ịrodymą, netgi kaip pateisinamą priežastį nesilaikyti nustatytos darbo drausmès arba galimybę atsisakyti vykdyti naujas veiklas („manęs to studijose nemokë“ [TD10]).

Tyrimo dalyviai svarsto apie motyvavimo siekti profesionalumo nepakankamuma. „Darbuotojų kompetencijos svarbios konkrečiose vietose, jie išmano ir jaučia atsakomybę už veiklos kokybę ir nuo jų priklauso įdomumas“ [TD2]. O tai, pasak pašnekovo, yra profesionalumas. Pokyčiai nesustoja („Ateina 
robotika, ateina konstruktoriai“ [TD2]) ir vadovui tenka ieškoti būdų ir motyvuoti darbuotojus naujai veiklai, atrinkti čia tinkamus, ,juk atlyginimas kol kas nedidejja“ [TD2]. Kurti motyvacijos sistemą, pasak pašnekovo, labai sudètinga, nes dažnai motyvacija dirbti yra susijusi su žmogaus pareigingumu kaip asmenine savybe. „Tu pažǐsti kiekvieną žmogų... ir supranti, kad vienam užteks tik gero žodžio, ir jis dirbs... ir tu gali būti toks nesąžiningas vadovas, kad tu jị išnaudosi <...>. Kitas galbūt darys tik tuo atveju, jeigu tu jam duosi priemoką. Bet [dirbs] tik tą dalyką, už ką jis gaus priemoką. O kitas... tai iš viso, ar tu jam duosi, ar neduosi [priemokos] - <...> norès - darys, nenorès - nedarys" [TD10]. Nors dabar ir yra ịstatymiška galimybe mokèti papildomai už pasiektus rezultatus, bet „tų pinigèlių kaip ir trūksta <...>. Riboto motyvavimo reiškia tai, kad aukšta kvalifikacija neatitinka atlygio $\langle\ldots . .>$. Tai yra problema“ [TD6]. Todèl „šiandien bibliotekininko profesionalumas labai priklauso nuo jo paties $<\ldots>$ [Nes] priversti žmogų kelti kvalifikaciją, domètis kaip ir nèra svertų“ [TD4]. Tyrimo dalyvio žodžiais, „su kolegėm direktorèm <...> pasikalbam, kad mes dar labai daug turim senų bibliotekininkų. <...>. Kurie niekur neskuba ir nieko nenori“ [TD9]. Viena iš galimų priežasčụ - nèra atestacijos ir pakankamo atlyginimu skirtumo („nèra absoliučiai to tokio bibliotekininko profesionalumo nustatymo“ [TD9]).

Profesionalumo kliūtis yra vienas darbuotojas filiale arba vienas iš grupés siekiantis profesionalumo. Kaip sako tyrimo dalyvis: „Nelygybė geroka $<\ldots>$. Kai kurie filialai, ten [daug ką] daro vienas entuziastas. Projektus rašo, velka ten viską <...>. O kitos tuo metu: „tai tau reikia, tai tu, maždaug, ir daryk $<$ <..>“ [TD8]. Nors dabartinè apmokejjimo sistema leidžia už gerą darbą padidinti kintamąją atlyginimo dalĭ, konfliktinè situacija tarp darbuotojų dèl to tik aštrèja: „bet ten pykstasi [nuolat]. Nei gauna tiek iš tụ projektų tų pinigų, ji tiesiog turi daug darbo“ [TD8]. Tyrimo dalyvio žodžiais, ypač sunku filialuose, kuriuose dirba vienas darbuotojas. Nors jų veikla gana skirtinga, gebejjimai lanksčiai dirbti su žmonèmis labai skiriasi. Tokiose vietose „šimtu procentų <...> priklauso nuo žmogaus“ [TD9]. Motyvuoti gerai dirbti darbuotojai patys sugalvoja patrauklių veiklų, o netinkamos darbuotojo asmens savybès (etikos nesilaikymas, nevalyvumas) atstumia lankytojus. Ir tada nepadeda net ir atnaujinta bibliotekos aplinka.

Kliūtys siekiant profesionalumo pasireiškia per mokymu nepakankamumą. Organizuojamos ir skatinamos teikti naujos paslaugos, pasak tyrimo dalyvių, turi būti iš karto ir kokybiškai paremtos tinkamais mokymais. Pavyzdžiui, „Robotikos mokymai palikti filmukais. O jeigu kas neaišku, tai filmuko nei paklausi <...>“; „Keitėsi UDK, milžiniškas darbas atliktas, pačių išsiaiškinta. Tik tada vyksta centralizuoti mokymai. Tikrai... viskam sugaišau daugybę laiko" [TD5]. Problema yra noras tobulinti kompetencijas nors „abstrakčiai visi už kompetencijų vystymą, [bet tai] riboja finansai ir siūlomas pasirinkimas“ [TD7].

Kaip profesionalumo kliūtị tyrimo dalyviai ịvardija kvalifikuotu specialistų trūkumą, jų nenorą dirbti provincijoje, už mažą atlyginimą. „Kaimuose specialisto su žiburiu nerasi“ [TD5]. „Ypač kaimo filialuose, netoli miesto kvalifikuoti žmonès nenori dirbt už mažą atlyginimą “ [TD9]. Tyrimo dalyvio žodžiais, „[1]abai trūksta $<\ldots>$ žmonių su neordinariu, strateginiu mąstymu $<\ldots .>$, kad sugalvotų kažką daugiau, kūrybiškai ir ịkvejptų kitus" [TD7].

Kaip grèsmę ir bibliotekininkų profesionalumo kliūtị du iš dešimties tyrimo dalyvių ịvardija atsitiktinius vadovus. Biblioteka tampa patrauklia vieta dirbti kadenciją baigusiems politikams ar kitiems vietos valdininkų proteguojamiems nespecialistams. „Atsirado didelis pavojus $\langle\ldots\rangle$, kad vadovų lygmeny atsiras labai daug perejūnų. Ypač regionuose, kur didelis noras politikų dalyvaut šiame procese ir kiekvienas pagal savo supratimo lygi“ " [TD7]. Ne iš tos profesijos atėję trumpam laikotarpiui nesuvoks institucijai keliamų tikslų, ir taip profesionalumui bibliotekose kyla grèsmè, galimos nepageidaujamos transformacijos. Pašnekovas teigia: „dažnai matau tarp savo kolegų viešųjų bibliotekų direktorių, kurie ị biblioteką atėjo pabūti iki kitų rinkimų ar iki pensijos <...>. Kartais jie tampa gerais bibliotekininkais, bet tai būna labai reti atvejai ir pavieniai“ [TD3]. Viena iš tokios grèsmès priežasčių, pašnekovès nuomone, nustatytos viešųjų bibliotekų direktorių kadencijos. Pasak jos, „tos kadencijos $<\ldots .>$ žmonėms, kurie turi didelių ambicijų“ $<\ldots>$ ir vadovavimu bibliotekai tik padaro žingsnị karjeroje <...>. [O tie žmonès, kurie] „,norètų visą širdị, viską atiduoti bibliotekai, tikrai ị tokias pozicijas neis" [TD7]. 
Profesionalumo kliūtis pasireiškia per bendros biblioteku politikos stoką. „Politikų nesuvokimas bibliotekų fondų komplektavimo reikšmès, jų tęstinumo, padarè nepataisomą žalą bibliotekoms, jų fondams. Čia negrižtama <...>“; „Nieko nedarant dèl bibliotekininkų kvalifikacijos kèlimo sistemos, praejus kažkiek metų bus labai didele problema, kaip su spaudinių komplektavimu. Kai sumažino drastiškai ir liko tuščia erdvė fonduose, taip gali atsirasti vakuumas ir žmogiškuosiuose ištekliuose. $<\ldots>$ sugriauta kvalifikacijos kèlimo sistema Lietuvoje ir <...> šiandien <...> nèra atstatyta “ [TD4]. Pasak kito tyrimo dalyvio, „kliūtis profesionalumo yra bendros nacionalinės bibliotekų politikos nebuvimas $<\ldots>$. Va Temperèj $<\ldots>$ pastatė naują biblioteką ir prie jos prijungė Švietimo centrą. $<\ldots .$. . Jie dirba ligoninèms, aptarnauja mokyklas, jie nekuria nacionalinès bibliotekos kiekvienam kieme. Dèl to jie efektyviai resursus išnaudoja, o pas mus to nèra" [TD3].

Profesionalumo kliūtimi tyrimo dalyve mato bibliotekininkų negebejiima tinkamai pristatyti savo dar$b a$, pademonstruoti jo vertę („Mes tiesiog stengiamès įtikt visiems $<\ldots .$. . Profesionalumas pasireiškia ir tuo, kad tu sugebi save pristatyti visuomenei“ [TD9]). Galbūt su tuo susijęs neigiamas visuomenès požiūris ị profesiją („bibliotekininkas nieko neveikia“) [TD9]. Kaip nurodo pašnekovas, iš bibliotekos išèjusi jauna mergina, ieškodama naujo darbo kitoje vietoje, trijuose pokalbiuose dèl darbo pasakiusi, kad dirbo bibliotekoje, sulaukè komentaro „mums tokių žmonių nereikia, nes jie ten įpratę nieko nedirbt“ [TD9].

\subsubsection{Profesionaluma išreiškiančios kompetencijos}

Temą Profesionaluma išreiškiančios kompetencijos sudaro keturios potemės: 1) Tradicinès (klasikinès) profesijos kompetencijos, sudarančios profesijos branduolį; 2) Inovatyviu veiklu kompetencijos, praplečiančios klasikines bibliotekų paslaugas; 3) Bendrieji gebejjimai / asmeniness savybès, tiesiogiai susijusios su profesionalia veikla (visas sąrašas pateikiamas 1 schemoje); ir 4) Sąlygos profesionalumui, per kurias atsiskleidžia bibliotekininkų veiklos profesionalumas.

Tradicines (klasikines) profesijos kompetencijos. Potemeje Tradiciness (klasikines) profesijos kompetencijos kalbama apie profesijos branduolị sudarančias kompetencijas, ilgą laiką būdingas bibliotekininkams. Tradicinemis vadinamos bendrosios (visoms pareigybèms büdingos) kompetencijos ir specifines (reikalingos konkrečias pareigas einantiems bibliotekininkams) bibliotekininko kompetencijos. Tyrimo dalyviai pabrěžè, kad specifines kompetencijas, reikalingas darbo vietoje, ilgainiui galima ịgyti dirbant, tačiau jas būtina tobulinti. Išryškèja kompetenciju atnaujinimo darbo vietoje skirtumai, tai lemia „skirtingų žinių poreikis. Ir modernumo skirtingas poreikis. Priklauso nuo to, su kuo tu dirbi“ [TD1]. Pavyzdžiui, komplektavimo skyriaus darbuotojai ịsigilinę i procesą, jis mažai kinta ir darbuotojas turi atnaujinti tik šios specifinès srities žinias. O aptarnaujantis skaitytojus personalas „turi kiekvieną dieną žengti su gyvenimo pulsu. Turi žinoti, kas svarbu vaikui, kas aktualu senjorui, kokie nauji poreikiai atsirado“ [TD1].

Svarbu, kad bibliotekininkas turètų „gerų savo specialybės žinių <...>, bibliotekininkystės ir bibliografijos pagrindus $\langle\ldots\rangle$, dirbti ar kraštotyros, ar bibliografijos srityje, ar, tarkim, aptarnavimo srityje“ [TD6]. Siekiant profesionalumo, būtina gilintis ị sritị, kurioje dirbama („struktūroje sudèliota ir pareigybèse. Kad kiekvienas žmogus turi savo sritị ir jisai gilinasi ị ją <...> ieško informacijos, teikia pasiūlymus, kaip ją tobulint. <...> Labai svarbu, kad žmonès norètų, mokètų ir galètų“ [TD6]). Bibliotekininkas nuo seno teikè rekomendacijas, ką skaityti. Tai, pasak tyrimo dalyvio, pagrindinè profesionalumą nusakanti kompetencija ir dabar. Tik modernus bibliotekininkas tam „turètų pasitelkti daugiau kūrybiškumo, išmonès" [TD2]. Visos tyrimo dalyvių ivardytos kompetencijos nurodytos ir suklasifikuotos 1 schemoje.

Inovatyviu veiklu kompetencijos. Potemejje Inovatyviu veiklu kompetencijos kalbama apie pastaruoju metu tapusias išskirtinai aktualias, netiesiogiai su profesinėmis veiklomis susijusias ar praplečiančias klasikines bibliotekų paslaugas kompetencijas („Būtina neužsidaryti nuo inovatyvių, naujų paslaugų" [TD5]). Visi tyrimo dalyviai aktualiais ir tam tikru lygiu būtinais bibliotekininkui profesionalui ivardija technologinio (kompiuterinio, medijinio) raštingumo igūdžius. Išskirtinai svarbiomis kompetencijomis tyrimo dalyvis ịvardija: 1) technologiju ivvaldyma ir 2) bendruomenei vykdomas edukacijas. 
Visi darbuotojai privalo ịgyti tokius technologinio raštingumo ịgūdžius, kad galètų teikti paprastas konsultacijas skaitytojams („bibliotekininkas turi padèti žmogui [elementarias technologines] priemones naudot, pažint, tiesiog gyvent... Nes technologinis raštingumas jau darosi [kai kuriems žmonèms] kliūtis issitraukt ị gyvenimą“ [TD3]). Todèl „technologijų žinojimas ir jų mokejjimas taikyt bibliotekiniam darbe yra būtina kompetencija“ [TD3]. Tai susiję su bibliotekos pastangomis pagelbèti bendruomenei, suteikti reikiamų žinių ir igūdžių. „Šiandien, kai uždarinẻja banko skyrių, kai žmogus negali prisiregistruot pas gydytoją $\langle\ldots\rangle$, kai jam reikia žemèlapio telefone - tai biblioteka yra ta vieta, kur jam gali pagelbèti. Pasakyt ir parodyt <...>, programèles parsisiųst“ [TD3]. „Svarbu, kad bibliotekininkas suprastų, kad jis labai svarbus bibliotekoj, kad jo nuomonė svarbi. Ir jis turi parodyti, kad žino daugiau nei tas iš gatvès atėjęs žmogus. Kad jis valdo vienokią ar kitokią technologiją, kuri yra nauja. Ir tai pasitelkia teikdamas paslaugas" [TD2]. Gebejjimas naudotis technologijomis rodo bibliotekininko profesionalumą: „jau niekada neatsiribosim nuo technologijų, ir bibliotekininkas turi būti labai motyvuotas, nusiteikęs geranoriškai, optimistiškai“ [TD2] - ne tik pats išmokti naujovių, bet ir būti nusiteikęs to pamokyti kitus. Technologijos pasitelkiamos ir skaitymui skatinti: „Norint pritraukti skaitytojus, ypač vaikus, reikia naudoti technologijas: „mes ị skaitymą pritraukiam per technologijas. Kuriam žaidimus“ [TD3].

Tyrimo dalyvis išskiria gebẻjimų įdomiai vesti renginius būtinybę: „Organizuoti renginius yra būtina. Tai ịrašyta ị visus pareigybių aprašus“ [TD1]. Organizuojant renginius profesionaliam bibliotekininkui reikia „išmanyti, ką tu kviesi, kas yra tie žmonès $\langle\ldots$. , kuom didžiuojasi mūsų šalis $<\ldots . .>$ išmanyti ir domètis profesionaliuoju menu“ [TD6]. Kita vertus, renginiais „mes turim būti naudingi tai bendruomenei $<\ldots>$, [kad skaitytojas] čia rastų tai, ko galbūt pas kitus nèra $<\ldots\rangle$ - būtent kitur nèra, o yra tik čia“ [TD6]. Tai pasireiškia ir per informacijos išteklių komplektavimą, ir per renginių organizavimą, turimų informacijos išteklių sklaidą.

Rengiant ir realizuojant projektus bibliotekininkams reikia papildomų igūdžių. Pasak tyrimo dalyvio, „dirbantiems su projektais būtina turèti idejjų, jas apvilkti ị gerą projektą, kad ji ekspertai gerai ịvertintų ir skirtų finansavimą. O tada - gebèti jị administruoti, sklandžiai įvykdyti“ [TD5].

Informacijos gausoje bibliotekininkas turi gebèti atrinkti svarbiausia: „gebejimas gerai orientuotis informacijos sraute ir ją teisingai surankiot, atrinkt, kokios reikia“ [TD8]. „Turi atsakingai informacijoj kapstytis <...> ir nesakyt: „tikrai čia taip, čia „Vikipedija“ rašo“ [arba] „pažiūrèkit ten „Google“, maždaug" [TD8]. Profesionalumą rodo gebejjimai atsakyti $\mathfrak{i}$ sudètingas užklausas, rasti tinkamą vartotojui informaciją, juk ,vaikai dažniausiai ateina su sąrašu $<\ldots>-$ nereikia galvot smarkiai $<\ldots>$. O kai $\mathfrak{i}$ šoną klausimas, tai sunkoka... taip ir išlenda neprofesionalumas" [TD8]. Kita vertus, bibliotekininkui svarbu orientuotis artimoje aplinkoje, kad galètų teikti konsultacijas. Nes kartais žmonès paklausia tokių netikètų „elementarių dalykų, pavyzdžiui, kaip jam patekti ị kitą miesto rajoną, kokiu autobusu nuvažiuot? Arba: kur yra artimiausia galerija?" [TD8].

Svarbus yra bibliotekininko gebejjimas veikla organizuoti pagal rinkodaros principus. Biblioteka neturi finansų šiai veiklai samdyti profesionalų, todèl svarbu, kad pats bibliotekininkas giliau sugebètų atlikti tyrimus, surinkti ir analizuoti duomenis ir siūlyti ką nors. Pasak pašnekovo, „vietinio lygio tyrimai tai tokie kažkokie naivūs ten būna. Kad ir maždaug: patinka ar nepatinka? <... . Tai... pažistami parašo, kad patinka, o kiti... tingi (juokiasi). Tie kiti tai tiesiog ten net nerašo nieko $<\ldots>$ turi gebèti [bibliotekininkai] ir analizuoti duomenis, ir $\langle\ldots\rangle$ pagal juos $\langle\ldots\rangle$ planuoti savo veiklą" [TD8]. Svarbiais inovatyviais gebéjimais pašnekovas ịvardija gebëjimus komunikuoti su politikais, išlaikyti demokratijos principus, neteikti kam nors pirmenybès: „vyksta susitikimai tiek su europarlamentarais, tiek su Seimo nariais $<\ldots>$. Reikia mokèti <...>, kad bibliotekininkas atitiktų bibliotekos ịvaizdi <...>, kad mes mylim visus ir kad žmogus atėjęs - jis renkasi. Mes turim būti demokratiški ir priimti visus" [TD6].

Bibliotekų profesionalumas priklauso nuo kitos srities specialistu pritraukimo į bibliotekines veiklas. Tyrimo dalyvių įsitikinimu, bibliotekoje turi dirbti profesionalus IT specialistas („,kad ta technika pastoviai veiktų <...>, jeigu kas nors neveikia, tai mes negražiai atrodom prieš visuomenę ir mes patys tada 
turim problemų“ [TD6]). Vienas pašnekovas didžiuojasi, kad bibliotekos renginius ir patrauklų skaitymo skatinimą organizuoja profesionali režisierè („todèl renginiai pas mus teatralizuoti, kurie traukia visuomenę. <...> Biblioteka turi žavų personažą Zuikị nulèpausį <...> su apranga, nudažytu veidu, jisai propaguoja knygą vaikams $<\ldots . .>$. Patraukli priemonè vaikams“ [TD6]).

Profesionaliai turi veikti ryšiu su visuomene specialistas. Norint išlaikyti susidomëjimą bibliotekos veiklomis, būtina nuolat profesionaliai palaikyti ryšius su visuomene. „Jeigu tu apie save nieko nesakysi $\langle\ldots>$, neskleisi informacijos [apie biblioteką], tų gerų patirčių, tai irgi bus neprofesionalu“ [TD6]. Taip žmonès sužino, ką naujo, ką įdomaus veikia biblioteka. Ir labai svarbu, kad informaciją rengtų ir skleistų profesionalas, „užtai mes jau turim kokius 10 metų specialistą ryšiams su visuomene“ [TD6]. Užtikrinama, kad būtų profesionaliai „skleidžiama tiek vizuali informacija, tiek tekstai. Kad jie būtų profesionaliai parašyti, be klaidų, geru stiliumi <...>. Kad būtų geros, kokybiškos nuotraukos" [TD6].

Profesionalumą rodo bibliotekininko gebejimas komunikuoti su įvairiu socialiniu grupiu atstovais. Tyrimo dalyvės žodžiais, „biblioteka dabar yra <...> ir socialinės atskirties mažinimo institucija. <...> Svarbu kalbètis, bendrauti su $<\ldots>$ [suaugusiais ir] vaikais iš įvairių šeimų. Ir kad tas bendravimas būtų palaikomas kultūringas, $\langle\ldots\rangle$ ir kad tas vaikas gerai jaustųsi bibliotekoje, ir kad tam bibliotekininkui nebūtų kančia <...> ar baimè, kad aš nemoku to daryti“ [TD6]. Visos tyrimo dalyvių ịvardytos kompetencijos nurodytos ir suklasifikuotos 1 schemoje.

Bendrieji gebëjimai / asmeninès savybès. Potemèje Bendrieji gebëjimai / asmeninès savybès abstrahuojamos tyrimo dalyvių mintys apie bibliotekininko profesijai svarbias asmens savybes ir jo bendruosius gebėjimus, kurie papildo profesinius igūdžius.

Profesionalumui šiuo aspektu svarbūs ne tiek gebẻjimai ar ịūdžiai, kiek asmens bruožai. Pasak pašnekovo, „yra ta gildija, kuri < ..> geriausiai žino, kaip $<\ldots>$ mokyt skaityt, $<\ldots>$ populiarint knygą $<\ldots>$. Bet čia labiau bendražmogiškos savybès“ [TD10]. Pasak kito tyrimo dalyvio: „Profesionalus bibliotekininkas tai yra tas, kuris šiai visuomenei patinka, tinka ir atitinka" [TD9]. Pašnekovas teigia, kad kolektyve yra akivaizdūs profesionalumo skirtumai, pasireiškiantys darbuotojų noru nuveikti daugiau (pavyzdžiui, keturi projektai per metus, vienas iš jų - tarptautinis) ir atvirkščiai - neturima noro nuveikti daugiau (pateikia pavyzdị: „aukštasis išsilavinimas, 20 metų stažas, absoliučiai jokios papildomos veiklos <...> “TD9]).

Taigi pirma profesionalumą žyminti kompetencija - bendrasis išprusimas. Tyrimo dalyvio žodžiais: „bibliotekoje turi dirbti išsilavinę žmonès“ [TD10]. Bibliotekininko įvaizdis, skaitytojų ir lankytojų akimis, turi būti „išsilavinusio ir kultūringo žmogaus“ [TD1]. Kitas tyrimo dalyvis profesionalumą sieja su pagarba savo profesijai ir baziniu išsilavinimu: „Va, tas bazinis mūsų paketas <... [kurị] savo rankose laiko VU baigusių žmonių komanda“ [TD7]. „Lygị išlaikyti, kad tu esi informacijos įstaigoje dirbantis žmogus, tu tai išmanai“ [TD6].

Profesionalumą rodo ne tik tai, kad bibliotekininkas išmano informacines technologijas. Šiuo aspektu svarbus žiniu siekis, noras pasiimti žinias, o ne priešintis joms. Daug priklauso nuo paties žmogaus: „Niekas nestovi vietoje, [svarbus] paties žmogaus noras tobulèti, gilinti [žinias]“ [TD1]. Profesionalumą rodo „[bibliotekininko pastangos] nelikt tokiam, kaip jis buvo pabaigęs mokyklą“ [TD9]. Svarbi savybè - gebejjimas prisiimti atsakomybę, pasiryžimas įveikti sunkumus (,juk, jeigu reikia, tu eini, atsistoji ir šneki“ [TD10]). Tokių asmeninių savybių svarba suponuoja kitą tyrimo dalyvio mintị: „nemanau, kad [bibliotekininko profesionalumas] yra kažkokios specifinès žinios ar kažkokios specifinès savybès <...>. Tai daugiau bendražmogiškos savybès - noras tobuletti, žinoti ir tas žinias taikyti savo darbe; būti lojaliam savo darbui. Ne aplinkiniams žmonems, ne valdžiai, bet pačiam darbui. Pareigingumas“ [TD10].

Išskirtinai svarbios tapo komunikacinès savybès, gebejjimai kalbinti, bendrauti su lankytojais. Profesionalumą rodo asmens gebejjimas tinkamai pasitikti atejusius ị biblioteką, bendrauti (,ateina, tai ne lentynas, ne senus langus, o pirmiausia žmogų pamato. Ir kaip tu atrodysi - ar šypsosies, ar sèdèsi susiraukęs“ [TD10]. Per tai bibliotekininkas atstovauja savo ịstaigai („trys darbuotojos dirba, ir pas dvi skaitytojų pastoviai daug, o pas vieną - ne. Tiesiog jai atnešè knygą, jinai nurašè, kitą užrašè ir viso gero. O kitos 
<...> pačios daug skaito, pasakoja, rekomenduoja, pataria žmogui, aptaria...“ [TD10]). Bibliotekininko, aptarnaujančio skaitytojus, profesionalumas darbo vietoje pasireiškia per gebejimą „teisinga linkme nukreipti besikreipiantį skaitytoją “ [TD4]. Jie turi turèti psichologinių žinių ir gebejimų taip pabendrauti su skaitytoju: „jeigu atejęs ị biblioteką jis gali ir nerasti reikiamos knygos, bet, pabendravęs su bibliotekinin$\mathrm{ku}$, jis gali išeiti ne su jausmu, kad jam nepasiseke, o... toks pakylètas. Nes ji bibliotekininkas nukreipé, sugebejjo jam paaiškinti, įtikinti, parodyti alternatyvas. Tai yra profesionalumo įrodymas“ [TD4]. „Jei nesi lankstus, nerandi su kitais bendros kalbos, sakykim, su paslaugos teikejjais, - tu esi žuvęs" [TD1]. Būtina aptarnaujančių skaitytojus darbuotojų savybè - lankstumas, geri komunikaciniai igūdžiai. Visi turi suvokti, kad „skaitytojas yra Dievas“ [TD7]. Juk pagal bendravimą su atejusiu ị biblioteką skaitytoju „[formuojasi] lankytojo <...> požiūris ị tave asmeniškai, ir ị instituciją, kuriai tu atstovauji“ [TD7]. Svarbu sugebèti pakviesti $\mathfrak{i}$ biblioteką - ị renginị ar pasiūlyti galbūt žmogui įdomią veiklą, perteikti ịdomiai jị dominančią informaciją („pakviest ị tokią biblioteką, kurioje aš pati norèčiau lankytis“ [TD2]).

Profesionalumas apima asmenybès motyvacija ir bendruosius gebẻjimus, pavyzdžiui, greitą orientacija, gebëjima mandagiai aptarnauti („mažai skirtųsi nuo bankų, kur [personalas] sèdi aptarnavime“ [TD8]). Darbuotojas turi gebèti rodyti dèmesį skaitytojams, taikyti turimas psichologines žinias, nemandagūs atsakymai, besikreipiančio lankytojo atstūmimas ar ignoravimas negalimi: „bijau, kad [taip] dangstomas neprofesionalumas“ [TD8]. Kaip sako tyrimo dalyvis: „Juk šiandien į biblioteką ateina $<\ldots . \ldots$ išvis gal kartais net nežino, ko ateina <...>. Idomiai praleisti laiką“ [TD8]. Ir su kiekvienu lankytoju reikia užmegzti ryšĭ, juos plèsti bendruomenès prasme. Aplinkoje, kurioje veikia biblioteka, reikia megzti kontaktus su veikiančiomis bendrijomis, organizacijomis. Pasak kito tyrimo dalyvio, būtina profesionalumo sąlyga - būti tolerantiškam, paisyti etikos taisyklių. Tai ypač svarbu didinant bibliotekos lankytojų ratą ir ịtraukiant patiriančius socialinę atskirtị lankytojus, pavyzdžiui, „mes vykdom įvairius projektus su vaikais iš socialinio užribio, tai mes juos su policijos pagalba dažnai tramdom. $<\ldots$. . Bibliotekininkas turi būti tolerantiškas ir kartu - laikytis etikos. Kviesti visus laikytis etikos" [TD3].

Profesionalumas reiškia bendruomenès poreikiu pažinima, nora pagelbèti. Pasak tyrimo dalyvio, „biblioteka yra ta vieta, kur sueina visų interesų žmonès. Labai ịvairūs, ịvairių interesų. Ir mes turim bandyt padèti tiems žmonèms, kad jie neatsiliktų nuo gyvenimo“" [TD3]. Tam reikia pažinti realius bendruomenès poreikius „mes turim pagauti pulsą, ko reikia gatvèj žmogui, ir tą pasiūlyt“ [TD3].

Svarbi kompetencija (asmeninè savybè) yra gebejjimas suderinti veiklai skirtingų kartu gerąsias savybes, jas tikslingai sujungti (,jeigu tu seną tetą [skatinsi], kad [ji] sudomintų jaunimą - tai nieko nebus. Tik jaunimas geriausiai žino, kas aktualu jų kartai [jaunos mamos] geriausiai supranta $<\ldots$. , ką vaikučiai nori skaityti. <...> Mano amžiaus damos tikrai žinos, ką daryti su senjorais. Jauni neatspès“ [TD7]). Kita vertus - jaunimui yra daug paprasčiau perprasti technologijas, bet pagyvenusios darbuotojos turi daug kantrybès, o jos ypač reikia mokant pradinio technologinio raštingumo senjorus. Geriausias profesionalumo rodiklis - atsitiktinai mieste sutiktų skaitytojų pagyrimas („Kokios nuostabios abonemente <...> mergaitès“ [TD7]).

Profesionalumas, kaip teigia tyrimo dalyvis, reiškiasi gebejimu turimas kompetencijas ir asmenines savybes pritaikyti naujose, kitose veiklose. Pavyzdžiui, ị biblioteką atėjusi dirbti iš banko mergina „labai i̇sisuko ị projektus $<\ldots .$. . Tiesiog žmogus negali sukauptų žinių niekur nepanaudoti“ [TD4]. Tyrimo dalyvis pasidalija patirtimi: „Łvairios žinios, sudètos ị vieną vietą, jos pagimdo dar didesnes žinias“ [TD4]. Tai susiję su Austrijos nacionalinès bibliotekos patirtimi, priimant ị darbą įvairių sričių specialistus ir vietoje juos mokant jau bibliotekinių dalykų. Pasak kito tyrimo dalyvio, profesionalumo požymis - gebejjimai sujungti turimas kompetencijas, pavyzdžiui, gilinimąsi ị literatūros naujienas, panaudojamas kuriant projektus. Pavyzdžiui, „literatūros meno žinojimas. <...>. Darbuotoja visada žino, kas geriausia yra Lietuvoj. Ir tai ịrašom rengdami projektus“ [TD3]. Šiuolaikinis bibliotekininkas gali vadintis profesionalu, jeigu geba suderinti skirtingas kompetencijas, palaikyti „pusiausvyrą tarp technologinio raštingumo ir naujos literatūros pažinimo“ "TD3]. 
Sąlygos profesionalumo raiškai. Mintys apie sąlygas, kuriomis atsiskleidžia profesionalumas, sudaro ketvirtą potemę Sąlygos profesionalumui. Labai svarbus yra bendraminčių noras padaryti gerai - „kaip biblioteką viešinti tinkamai, ką joje surasti gero" [TD10]. Svarbus pats suvokimo apie profesionalumą pasikeitimas: „[buvo] - neatejo skaitytojas, - na, tai kas? Gal jis rado kažką geriau. [Dabar mąstoma]: tu ir turi pasiūlyti kažką geresnio [kad skaitytojas ateitų]. Tai ne skaitytojo, o mano problema" [TD10].

Svarbi profesionalumo sąlyga - universitetinis, geriau - profesijos srities išsilavinimas. Pasak tyrimo dalyvio: „[profesinis] išprusimas ir kompetencijos [yra] kertinis dalykas <...>. Tu atëjai jau žinodamas, kas tai yra katalogas, kas yra skaitytojo aptarnavimas, kuo vaikų poreikiai skiriasi nuo senelių" [TD7]. Kitas tyrimo dalyvis sako: „svarbu, kad „būtų baigęs universitetines studijas <...> dabar visi ateina su aukštuoju išsilavinimu, mat nebėra deficitas tas išsilavinimas“ [TD1]. Kitas tyrimo dalyvis mąsto: svarbu, „kad bibliotekininkas būtu išsilavinęs, kad jis turètų nuovoką, suvokimą ir išmanymą ịvairiose srityse $\langle\ldots$. , kad būtų apsiskaitęs, domètųsi daug kuo“ [TD6]. Tada, pasak tyrimo dalyves, „„̧staiga igauna tą opiniją iš visuomenès. Kad jisai pasitiki bibliotekininku ir atėjęs, ir jis mokès tas knygeles parinkti. Nesvarbu, kas ateis - ar daktaras, ar mokytojas, ar kitas žmogus $\langle\ldots$. . Tai bibliotekos prestižas $\langle\ldots$.$\rangle , kad čia dirba profesionalūs žmonès“ [TD6].$ Kita tyrimo dalyvė susižavejjusi pasakoja apie [buvusiose] Vilniaus universiteto bibliotekininkystės studijose igytą kompetencijų rinkini, kuris garantavo studentams galimybes įsidarbinti dar studijuojant: „turi pats gerai mokèti dirbt su informacija ir kad galètų mokinti kitus $<\ldots .>$, moka sisteminti informaciją, moka surasti, kas nauja, ar kažkokį projektą padaryt. Jie viską moka ị viena, neišsibarsto <...>. Šito bibliotekoj reikia“ [TD2]. Intensyvių pokyčių laikais, pasak tyrimo dalyvio, „žmonès turi būti pasirenge naujovéms, iššūkiams, kurie kiekvieną dieną juos sutinka“ [TD4]. Dauguma bibliotekininkų yra tokie, ,jeigu [tik bibliotekininkas] nèra savyje užsisklendęs“ [TD4]. Todèl, respondento nuomone, „kompetencijų dabar pakaktų $<\ldots>$, jeigu tik visi jas tinkamai panaudotu [TD4]. Viena iš profesionalumo sąlygų - gilintis ị savo veiklos sritị, todèl darbdaviams svarbu padèti rasti žmogui savo vietą ten, kur geriausiai atsikleidžia asmenybe ir turimos kompetencijos. Tyrimo dalyvis teigia: „Bibliotekininko profesiją anksčiau rinkdavosi daugiau užsidarę žmonès, todèl nėra problemų su nurodymų vykdytojais. Bet savo vietą čia gali rasti ir strategai, ir taktikai, ir tie, kurie viską sudèlioja ị lentynèles“ [TD7]. Pasak kito tyrimo dalyvio, „buvo, kad 20 metų jis dirbo ir neatsiskleidè. O ji perkèlè kitur - ir jis sulig pirmais metais atsikleidè“ [TD2].

Sąlyga profesionalumui reikštis tyrimo dalyvis vadina "gebèjima pritraukti lëšas“ [TD6]. Tai reiškia „išgyvenimą $<\ldots . .>$, bibliotekos darbo organizavimas tuo paremtas $<\ldots .>$ padidintas truputeli finansavimas literatūros ịsigijimui ir plius dovanų dar gaunam, ir per projektus užsidirbam. $<\ldots>$ tada galim kažkaip tai jaustis oriai prieš savo skaitytojus <...>. Aš galvoju, kad tai susiję su profesionalumu. <...> Žavesnès veiklos ramstis yra projektų rašymas, jų laimèjimas ir jų igyvendinimas“ [TD6].

Tyrimo dalyvio nuomone, viešujų bibliotekų modernizavimo programa sukūrẻ sąlygas bibliotekoms būti matomoms ir toliau siekti patrauklumo ir iš naujo iškyla profesionalumo poreikis: „Mūsų valstybe $<\ldots>$ pripažino, patvirtino [viešųjų bibliotekų modernizavimo programą]. Džiaugtis reikia, kad ta programa veikia ir tiek naujų bibliotekų. Dabar tikrai ir mums ne sarmata, kai pas mus atvažiuoja. Ir mes jaučiamès ne tokie nuskriausti, kai ten nuvažiuojam“ [TD6].

\subsubsection{Profesionalumo reikalavimai}

Temoje Profesionalumo reikalavimai išskirtos trys potemès: 1) Isidarbinant keliami reikalavimai; 2) Profesionalumo vystymo sistema; 3) Profesijos neapibrëžtumas.

Isidarbinant keliami reikalavimai. Profesionalumas priklauso nuo formalių reikalavimų, keliamų pradedant eiti pareigas, ir kompetencijų ugdymo dirbant. Pasak tyrimo dalyvių, oficiali tvarka šalies mastu, priimant $\mathfrak{i}$ bibliotekininko pareigas, numato A ir B specialistų lygius. A lygio specialistai turi aukštajji universitetinị išsilavinimą, B lygio - kolegijų arba technikumų išsilavinimą [TD5, TD3]. Gana svarbu, pažymi vienas tyrimo dalyvis, kad formaliuose reikalavimuose nenumatyta finansinè profesionalumo tobulinimo paskata, nes „apmokèjimui turi ịtakos [tik] darbo stažas“ [TD5]. 
Profesionalumo reikalavimus administracija ịvardija darbo skelbimuose, tokiu informacijos surinkimo būdu rẻmèsi Izraelio tyrẻjai. Tačiau Lietuvoje darbo skelbimai neišlieka, surinkti pakankamą tyrimui kiekị einamụjų skelbimų ilgai truktų, todèl informacijos apie formuojamus reikalavimus ir plačiau apie esamą įdarbinimo bibliotekoje situaciją pasiteirauta pačių tyrimo dalyvių.

Pretendentu daug, profesionaliu darbuotoju trūksta. Keletas tyrimo dalyvių džiaugiasi, kad neturi problemų ieškodami darbuotojų. Manoma, kad tam ịtakos turi atsinaujinęs bibliotekos pastatas („gal kad biblioteka pakeitè savo vaizdą“ [TD4]). I vieną vietą būna po 40, net 50 pretendentų, nors „„̌ia didelių pinigų niekada nebus“ [TD4]. Kitas tyrimo dalyvis teigia, kad darbo skelbimai rašomi retai, nes dažniausiai atsirenkama iš ị biblioteką atsiųstų gyvenimo aprašymų, o „siunčia tikrai nemažai <...>, ị savaitę kokie 3-4 būna" [TD8]. Panašiai argumentuoja ir kiti tyrimo dalyviai [TD1, TD2]. Pabrežiama, kad kandidatų eiti pareigas būna daug, susiduriama su problema „atsirinkti tinkamą pretendentą“ [TD10]. Kartais tai tiesiog dèl didelio pretendentų skaičiaus, o kartais - dèl oficialių dokumentų ir realijų neatitikimo. Pasak tyrimo dalyvès, būna, kad „viskas tvarkoj su dokumentais, yra nemažai patvirtinimų apie igytas kompetencijas, bet va... tau viduj kirba, kad tu gali turèti problemų <...>, ir tai pasitvirtina “ [TD1]. Todèl išskirtinai svarbu įdarbinant yra pokalbis su pretendentais, prašoma bendruomenès rekomendacijų.

Kito tyrimo dalyvio žodžiais, „didžiausia problema - izžvelgti žmoguje profesionalumą“ [TD9]. Turimi dokumentai ar igytos kompetencijos ne visada dirbant pasiteisina: „atrodo, yra potencialas, turi gebe்jimų, turi supratimą, bet kai pradeda dirbt - nèra to“ [TD9]. Dèl nedidelių atlyginimų „buvo tokių vietų, kur su aukštuoju rast žmogų sudètinga" [TD9], ’ trūkstamq vieta pretenduoja toje vietovejje gyvenantys nekvalifikuoti asmenys (,,atėjo darbintis 8 klases baigę <...>, profesines mokyklas baige“ “TD9]). Pašnekovè piktinasi, kad tokie asmenys ,isivaizduoja kažkodèl, $\mathrm{kad}<\ldots>$ bibliotekoj ten nieko nereikia. Tik sėdi ten, užrašo knygeles ir viskas" [TD9].

Kiti tyrimo dalyviai pabrèžia, kad sunku rasti kvalifikuota naują darbuotoją. Vieno tyrimo dalyvio teigimu, susiduriama su specialistų, baigusių bibliotekines studijas, trūkumu (to anksčiau nebuvo). Be to, nusivilta įdarbinant jaunus specialistus. Neseniai įdarbintas srities studijas baigęs asmuo „nuvylè, <...> dalykinių žinių nerasta, projektų ruošti taip pat negeba, o labai nustebino, kad galima baigti universitetą nemokant lietuvių kalbos“ [TD5]. Taip teigia ir kitas pašnekovas: „ne tik kad jų kalba nevaizdinga, bet ir kablelių nemoka sudèti. Ir kuo toliau nuo Vilniaus, tuo daugiau tokių faktų“ [TD7]. Kaip sako kitas tyrimo dalyvis: „Diplomų daug, o kompetencijų nelabai“ [TD3].

Vieno tyrimo dalyvio žodžiais, reikalavimai, keliami naujai įdarbinamiems į biblioteką, paremti ịsitikinimu, kad „pirmiausia [asmuo] turi būti specialistas“ [TD6]. „Pagal pareigas ir jam numatomas funkcijas priklauso, koks specialistas, - bibliotekininkams (baigęs šios specialybės studijas), dailininkas - turintis šios srities išsilavinimą ar ryšių su visuomene specialistas" [TD6]. Filialuose ịdarbinti kitos srities studijas baigę žmonès (pavyzdžiui, agronomai) turi būti inteligentai, išprusę žmonès, norintys dirbti bibliotekoje, pažistantys vietinę bendruomenę. Visi jie mokosi bibliotekoje bibliotekininkystės pagrindų, vietoje konsultuojami specialistų. Pašnekovas pažymi, kad įdarbinti nespecialistai adaptavosi, „džiaugiasi, kad turi darbą. Tai yra irgi viena iš motyvacijų, <...> jie vertina darbą, nori dirbti, ir nori tą daryti gerai“ [TD6]. Pasak kito tyrimo dalyvio, viešosios bibliotekos personalo sistemoje turi būti informacinių technologijų specialistai („IT specialistų bibliotekoje dabar yra gal šeši iš viso. Nes su technologijom tai nieko nebus kitaip“ [TD3]).

Pasak kito tyrimo dalyvio, „minimalių reikalavimų [įsidarbinti] nėra $<\ldots .>$, visada nori priimti geriausią [kandidatą]. Jei minimalius [reikalavimus] nuleisi, tai ir priimsi minimaliai. O jeigu pakelsi kartelę... Kuo daugiau kompetencijų reikalauji, priimdamas ił darbą, tuo aukštesnès kvalifikacijos ateina žmonès“ [TD4]. Kitas tyrimo dalyvis išdèsto savo kredo: „Man nè vienas meras nèra užkoręs nè vieno kadro. Per ketvirtị amžiaus. Mes žinom, kad būna labai visaip“ [TD7]. Kita vertus, tenka susitaikyti su realybe: „Kaime puse etato tai tu žvaigždès neprisikviesi“ [TD3]. Vis dèlto reikalavimai griežtejja: „kaime, aš gi atsimenu, bibliotekininkai būdavo tokie su lengvu debilumu, kai kurie, tai dabar mes jau negalvojam apie tokị kontingentą" [TD3]. 
Pagrindiniai kriterijai, tikintis profesionalumo. Pagrindinis kriterijus įdarbinant bibliotekininką yra universitetinis išsilavinimas, kai kurie pašnekovai pabrěžia, kad pirmenybe teikiama baigusiems universitetines bibliotekines (ar jiems artimas) studijas. Dauguma pabrèžia, kad pagrindinis kriterijus - platus išsilavinimas, žinių siekis, etikos laikymasis [TD1, TD3, TD4, TD6, TD7, TD9, TD10]. Teigiama, kad rajonuose baigusių bibliotekines studijas trūksta, o kitados baigę aukštesniąsias bibliotekines mokyklas kandidatai nèra tinkami, jeigu jie nedirbo ir nekèlè kvalifikacijos. Pasak tyrimo dalyvio, „universitetas negali tau suteikti visų kompetencijų. Tau duoda platų išsilavinimą ir tu turi rasti sprendimą. Tu randi sprendimą, pasinaudodamas ta baze, kurią gavai. <...> Rokiškio kultūros mokyklą baigei prieš 30 metų. $\mathrm{Na}$, ir kas? Tai nieko nebaigei. Tai čia jau netinka“ [TD3].

Tyrimo dalyvio manymu, iš dalies tenkina absolventu iš kitu profesiniu studiju įdarbinimas („tai žmogus turi savo kreizo. Atsineša savo kontaktus, savo žinojimą“ [TD7], o bazinių profesijos dalykų tenka mokyti vietoje). Kitas tyrimo dalyvis sako, kad naujai ịdarbinami dažniausiai „baigę lietuvių kalbą ar kalbas“ [TD2]. Kita vertus, pašnekovas kalba: „Negalěčiau pasakyti, kad dabar bibliotekininkui reikètų baigti tas studijas, kad galètų dirbt bibliotekoje <...>. Kaip kad mes kažkada baigèm VU ir jeigu būtume negilinę“ [TD2]. Nors pirmenybė teikiama baigusiems universitetines studijas, pasak pašnekovo, „privalumas yra pačiame žmoguje $<\ldots$. . Jeigu jis žingeidus, tai [nesvarbu], kad baigęs kolegiją, jis tikrai [kitus] pralenkia“ [TD2]. Kito tyrimo dalyvio nuomone, „diplomo pavadinimas nelabai turètų būti svarbus $\langle\ldots\rangle$ pagrindas, priimant ị biblioteką $\langle\ldots\rangle$, [norint] apsimokyti dirbt LIBIS $\langle\ldots\rangle$, nebūtina būt baigus bibliotekininkystę <...>. Jeigu turi gerus organizacinius-vadybinius gebejjimus, tai tikrai suorganizuosi ir programą, ir surasi, ko reikia bendruomenei“ [TD8].

Vienas tyrimo dalyvis pasidalija žiniomis apie Austrijos nacionalinès bibliotekos patirtį: ,austrai nerengia $<\ldots>$ bibliotekininkų. Bet jeigu tu nori dirbt $<\ldots>$ nacionalinejje bibliotekoje, turi žinoti minimaliai dvi senąsias kalbas, $<\ldots>$ graikų, lotynų, ir tu turi būti [kažkokios srities] specialistas. Ima mediką <...>, gali imti inžinierių, bet kokios specialybès. Ir jis dar dvejus metus turi praeiti $<\ldots>$ jų pačių suorganizuotus mokymus" [TD4].

Pokalbio su pretendentais svarba. Atliekant atrankas, pretendentu profesionalumui vertinti svarbus yra pokalbis su pretendentais, nes atitiktị pareigoms ir asmenines žmogaus savybes geriausiai galima pastebèti tiesiogiai bendraujant per susitikimą ar atliekant tikslingai pateiktas užduotis. Vienas tyrimo dalyvis per atranką pateikia užduočių, kurias pretendentai per tam tikrą laikotarpi gali atlikti namuose. „Taip išvengiama nejaukumo ir sukaustymo" [TD10] per susitikimą ir pasimato žmogaus kūrybiškumas [TD10]. Labai svarbi savybe - empatija, apie kurią tyrimo dalyvis sprendžia iš pretendento pasakojimų, tam tikrų smulkmenų, kurios atskleidžia jo asmenybę ir aplinkinių vertinimą. Apie pretendento atsakomybę sprendžiama iš to, ar kandidatas dirbti pasidomejjo biblioteka, jos veikla (,ar atëjo pabandyti, ar nori dirbti") [TD10].

Per pokalbi pretendentas gali daugiau pasakyti apie save, nusakyti papildomas kompetencijas ir kaip jas galima panaudoti. Vienas iš tyrimo dalyvių prisimena atveji, kai pretendente papasakojo, ką ji veikẻ ankstesniame darbe (atlikdavo apklausas internetu ir jas apibendrindavo), ir tai nulèmè, kad ji buvo priimta dirbti, nors tik iš gyvenimo aprašymo teigiama nuomonè nebuvo susidariusi [TD2]. Pasak kito tyrimo dalyvio, per pokalbị su pretendentu ị darbo vietą pasiteiraujama apie pomėgi, atkreipiamas dėmesys $\mathfrak{i}$ tai, ar asmuo yra bibliotekos skaitytojas, ar yra nuveikęs ką nors, susijusio su skaitymu, kultūra. Pokalbis sukasi apie tai, ką asmuo gali pasiūlyti skaitytojams. Kita vertus, stebima, kaip pretendentas bendrauja, kokias reikalingas darbui papildomas kompetencijas turi [TD1]. Per pokalbi paaiškèja ir pretendento kūrybiškumas, jo gebejjimai rašyti, literatūros išmanymas [TD5]. Juk nesinori „kad ateitų <...> su iš anksto suspaustom smegenim, sudètais ị stalčiukus [įsitikinimais]“ [TD7].

Svarbios bendruomeniu rekomendacijos. Idarbinant $\mathfrak{i}$ filialus, kuriuose bibliotekininkui išskirtinai svarbus ryšys su bendruomene, pasireiškia bendruomeniu rekomendaciju praktika. Vienas tyrimo dalyvis teigia, kad situacija čia keičiasi, „kaimo teritorijoje atsiranda aukštos kompetencijos žmonių, jie tiesiog 
ten gyvena $\langle\ldots\rangle$. Jie visai noriai ateina dirbt $\mathfrak{i}$ biblioteką, jau kokius du turim“ [TD3]. Kaip teigia kitas tyrimo dalyvis, „atsižvelgiama ị tai, kad būtų žinomas bendruomenei, turètų su ja gerus ryšius“ [TD5]. Trečias tyrimo dalyvis pasakoja, kad pasidomima, kodèl asmuo nebedirba ten, iš kur išèjo. „Mažose bendruomenèse rekomendacijos yra ypač svarbu“ [TD1].

Pretenduojančiu i pareigas privalumai. Juos tyrimo dalyviai ịvardija taip:

„Svarbiausias dèmesys kūrybiškumui, technologijų žinojimui ir norui tobulèti. Tai <...> trys banginiai, ant kurių laikosi. Kūrybiškumui skiriu didžiausią dèmesį " [TD3].

Noras tobulèti: „Jeigu tu nežengsi kasdien pirmyn, vargu ar būsi labai profesionalas“ [TD1]. Esminiai profesionalumo reikalavimai kompetencijoms: sklandi lietuvių kalba, kompiuterinis raštingumas, užsienio kalbos naudojimas, gebejimas bendrauti“ [TD1].

Daugiausia dèmesio kreipiama ị bendruosius norinčių įsidarbinti bibliotekoje gebëjimus, reikalingus konkrečiai pareigybei. Ypač sunku parinkti žmogų darbui filiale („ten reikia, kad jisai būtų visų sričių specialistas. Ir bibliografas, ir bibliotekininkas, ir kraštotyrininkas, ir renginių organizatorius..." [TD9]). Labai svarbūs gebëjimai dirbti su vaikais, kompiuterinio raštingumo gebëjimai, motyvacija dirbti vienam: „Skaudu, kai nusivili žmogum $<\ldots>$. Ar išsikvepia, vienam dirbt sunku $<\ldots$. , turi suktis iš visų padéčiu pats $<\ldots>$, spręst viską pats, mokytis nèra iš ko“ [TD9]. Tokiais atvejais svarbiausia, kad turi motyvaciją dirbti, tobulèti.

Nors patirtis bibliotekoje yra vertinama teigiamai, bet „pas jauną akys dega“ [TD7] - taigi, pirmenybė suteikiama entuziastingiems, motyvuotiems dirbti žmonems [TD7].

Prioritetai: 1) kompiuterinio raštingumo ịgūdžiai, gebẻjimas dirbti MS Office programomis, 2) užsienio kalbos (rusų, anglų) mokejjimas. Privalumas - geri organizaciniai ir vadybiniai gebëjimai [TD8].

Prioritetai skiriasi pagal pareigybes, $\mathfrak{i}$ kurias vykdoma atranka, pavyzdžiui, kadidatuojant $i \mathfrak{\text { ad }}$ adinistracijos komandą (metodininkè ir direktoriaus pavaduotoja) prioritetas yra aukštasis bibliotekinis išsilavinimas. Kandidatuojant ị skaitytojus aptarnaujančias pareigas prioritetas yra „sugebejjimas komunikuoti. Net bendravimo kultūra" [TD10]. Svarbus kriterijus - informacinis ir technologinis raštingumas. Sprendimas apie tinkamumą eiti pareigas daromas pagal pretendento išreikštą motyvaciją dirbti. Pašnekovas piktinasi, kad vis dar dažnai sakoma: pavargau nuo atsakomybès (ankstesniame darbe) ar ịtampos. Tai rodo, kad vis dar gajus ịsitikinimas, jog bibliotekoje darbas lengvas ir ramus. Vis dellto jau galima pateikti ir kitokių pavyzdžių: priimta dirbti mergina, kurios motyvas buvo „noriu dirbt su žmonèmis, matau besikeičiančią biblioteką ir ji man patinka" [TD10].

Prioritetas teikiamas igūdžiams gerai valdyti plunksną, nes tai reikalinga rengiant projektus. „[Pirmenybę turi] gebantys vartoti užsienio kalbas, ypač anglų, nes tai reikalingi igūdžiai tarptautiniams projektams kurti ir igyvendinti. Komunikabilumas, kuris yra būtinas veikloje“ [TD2].

Pirmenybe teikiama turintiems darbo ieškomoje pozicijoje patirties (,jeigu dirbęs panašų darbą, gal kokioj kitoj bibliotekoj Lietuvoje ar Europoje“ [TD4]).

\subsubsection{Profesionalumo vystymo sistema}

Bibliotekininkui įsidarbinus, kyla poreikis reguliariai kelti kvalifikaciją, igyti naujų kompetencijų. Keičiasi aplinka, keičiasi darbo procesai, priemonès, kuriomis tenka naudotis, nuolat kinta technologijos, - tam reikia naujų žinių ir igūdžių, tampančių kompetencijomis darbo vietoje. Visi kalbinti tyrimo dalyviai išsakè pastabų apie esamą kvalifikacijos kèlimo sistemą, svarstė apie galimybes ją tobulinti.

Oficialios bibliotekininkų profesionalumo vystymo sistemos tiriamuoju laikotarpiu nèra, yra jos elementai, apie kuriuos dažniausiai kalbama. Išsakomos mintys apie tokios sistemos poreikị, esamus ir galimus profesionalumo lygius, profesionalumą, paremtą bazinių profesijos žinių ir kompetencijų rinkiniu, ir jau dirbančių bibliotekose profesionalumo vystymą. Dėstomos jzžvalgos apie pageidautinas profesionalumo sistemos sąsajas su finansais.

Profesionalumo vystymo sistemos poreikis. Pasak tyrimo dalyvio, profesionalumo reikalavimai akivaizdžiai pasikeitė: „Kažkada galèjo bibliotekoj bele kas dirbt ir taip buvo dažnai. Dabar [vadovas] nori, 
kad dirbtų kompetentingas žmogus. Nes reikia stengtis, kad ateitų žmonės [ị biblioteką]. O jie ateina i geras paslaugas, o i prastas neina“ [TD3]. Kita vertus, reikalinga jau dirbančių bibliotekininkų kompetencijų tobulinimo sistema. Pavyzdžiui, X miesto bibliotekų tinkle priimant ị darbą bibliotekininkus aiškus prioritetas - universitetinis bibliotekinis išsilavinimas, ir dauguma darbuotojų ji turi [TD8]. Tačiau tolesnis profesionalumo vystymas nenustatytas ir dèl to susiduriama su problemomis. Pasak tyrimo dalyvio, „turètų būti nustatyti <...> griežti kvalifikaciniai reikalavimai. Nes dabar pareiginės instrukcijos rašo <...>, kad tarsi viskas vyksta savanoriškų principų laikantis. Reiktų nustatyti, kad, pavyzdžiui, toj darbo vietoj kažkokią inovaciją per metus įdiegti, ar kažkokių konkrečių dalykų kad galètum pareikalaut. Galbūt net priimant ị darbą, ị tą vietą, lengviau būtų $<\ldots .$. , jau žinant $\langle\ldots\rangle$ reikiamas kompetencijas. $<\ldots>$ [situacijose, kai kažkas] riejasi dèl grafiko, tai galètum pareikalaut $<\ldots .$. . Kokių privalomų dalykų padarei? Dabar tik rekomendacijos tokios [abstrakčios] “ [TD8]. Iš to išeina, kad kas nors daro daug, o kitas - nieko nedaro ir negali iš jo pareikalauti.

Pasak vieno iš tyrimo dalyvių, „[profesionalumo] sistemą turètumèm kurti mes visi. Tą turètų kurti visų pirma Kultūros ministerija, kuri atsako už bibliotekų politiką <...>. Tokioje sistemoje būtina „motyvacija, kad <... žmogus galètų daryti karjerą toj pačioj savo srity“ [TD4].

Profesionalumo lygiai. Mąstydami apie profesionalumo sistemos elementus, tyrimo dalyviai svarsto apie galimus ar esamus profesionalumo lygius (kaip jie gali būti apibrèžti).

Profesionalumo lygius tyrimo dalyvis sieja su esama pareigybių struktūra: „Centrų vadovai ir yra vyriausieji specialistai - jų kvalifikacija viena. Toliau - vyresnieji specialistai, jų kvalifikacijos lygis yra kitas, ir yra bibliotekininkai, jų kvalifikacijos lygis irgi yra atitinkamas. <...> Vedantieji specialistai, vyriausi, turi išmanyti žymiai daugiau $<\ldots>$ nei eilinis bibliotekininkas, kuris $<\ldots>$ turi apibrèžtą savo veiklų ratą" [TD4].

Kitas tyrimo dalyvis mato keturis skirtingus profesionalumo lygmenis bibliotekoje, kuriuos sieja su bibliotekos struktūra: „1) filialo bibliotekininkas <...> ar ten skaitykloj prie kasdienio <...> aptarnavimo; 2) dirbantys su informacija bibliografijos skyriuje; 3) dirbantys su projektais $<\ldots$. “; 4) ir strategai, kūrybingi motyvatoriai [TD7].

Mąstydamas apie kompetenciju lygius ir galima profesionalumo sistema, kitas tyrimo dalyvis išskiria du bibliotekininku pareigu lygius. Tai 1) komplektuotojai ir metodininkai bei 2) aptarnaujantys skaitytojus darbuotojai. Pasak tyrimo dalyvio, tai nèra hierarchinè sistema, tai tiesiog skirtingu kompetenciju reikalaujantys lygiai. „Dokumentų komplektavimo-tvarkymo skyrius - tai <...> yra bibliotekos širdis, $<\ldots>$ aukštasis pilotažas. Be specialaus mokslo, be specialių žinių tai tu tikrai nepadarysi“ [TD10]. Aptarnavimo barų darbuotojų lygis yra kitas. „Nesakau, kad žemiau. Nes su žmonemis bendraut yra didelis menas. Bet jie gauna jau savotiškai sukramtytą informaciją. Kaip ją panaudos, priklauso nuo jų bendrụju gebëjimų“ [TD10].

Kitas tyrimo dalyvis mano, kad esama bibliotekos organizacinè struktūra išreiškia profesionalumo lygius: „juk ne veltui kažkoks žmogus tapo vedèju $\langle\ldots$. , nes iš jo yra reikalaujama platesnių žinių“ [TD1]. Taip ir metodininkai turi būti didesni profesionalai nei besikreipiantys ị juos. „Nes skambina jam $<\ldots>$ tikèdamasis gauti atsakymą" [TD1]. Administracija yra aukščiausias lygmuo, neturi „kiekvieną dieną keistis, kuo gali - gelbèti savo kolektyvui, [atliepti] reikalavimus, kurie keliami iš istaigos steigèjų" [TD1].

Galimo profesionalumo vertinimo įžvalgos. Vienas iš tyrimo dalyvių mąsto, kad profesionalumo matavimo sistemoje turi büti atsižvelgta ị daugeli faktoriu ir sukurta formulé, kuri apimtų bendrajj atlygio už tam tikras veiklas ir pareigybes numatymą. Sistema turi apimti ne tik išsilavinimą, bet ir žmogaus i̇dirbị, pastangas ir rezultatus. Formuleje turètų atsispindèti ir vietos specifika (lankytojų skaičius, pateiktos inovacijos, naujai pritraukti žmonès ị biblioteką). Tokiai veiklai reikètų pasitelkti profesines nevyriausybines organizacijas, pastudijuoti kitų šalių patirtị. Pasak tyrimo dalyvio, formulès sukūrimas atkurtų teisingumą, „kad toks <...> mechanizmas vienodai veiktų visoj Lietuvoj <...>. Nes šiuo metu 
kaip mums pasiseka kiekvienam rajone tvarkytis, taip mes ir tvarkomès. Gauni daugiau pinigų - motyvuoji daugiau" [TD6].

Vienas tyrimo dalyvis svarsto, kad profesionalumo lygiai galètų būti išskiriami „pagal vartotojų kažkokị <...> pasitenkinimo lygị paslaugomis. $\mathrm{Nu}$ nẻra kuo kitu išmatuoti, iš tiesų <...> pagal tai, kiek jisai sugeba savo bendruomenei <...> paslaugų naujų <...>, inovacijų kažkokių duoti“ [TD8].

Pasak kito tyrimo dalyvio, „[užsienyje] yra bibliotekininkai, kurie turi bendrajj̨ aukštajj̨ išsilavinimą $<\ldots>$ ir kiti, kurie galètų, tarkim, išduoti knygą <...>. Mūsų šaly kaip ir nèra tokių kategorijų. Bet aš galvoju, kad visai $<\ldots .>$ neblogai būtų $<\ldots .>$. Nes tada gal ir $<\ldots .>$ aukštos kvalifikacijos specialistui gal galètum ir algą padidinti $<\ldots$. . Bet tai perspektyvos dalykai“ [TD6].

Kitas tyrimo dalyvis mąsto, kad galètų būti bibliotekininkų kategorijos „kaip mokytojas. Mokytojas vyr. mokytojas - metodininkas - ekspertas. Jie turi tas kategorijas ir jiems dedasi kažkokie finansiniai dalykai“ [TD9]. Tai tarsi profesionalumo lygiai, kurie priklausytų „nuo [kvalifikacijos] kèlimo, nuo profesionalumo, nuo veiklų - daugiau“ [TD9].

Pašnekovo nuomone, Lietuvoje aukšto lygio pareigas einantys bibliotekininkai (ne tik direktoriai) turi būti vertinami, konkuruoti siekdami toliau eiti pareigas: „kas treji-penkeri metai tau kvalifikacinis egzaminas. Ir tu stengiesi siekti kažko ir pasiekti. Produktą kažkokị parodyt. Bent jau pastangas padaryt“ [TD3]. Kaip profesinio vertinimo ir profesinių žinių minimumo pavyzdị tyrimo dalyvis pateikia JAV kasmet vykstančią bibliotekininkų konferenciją, kurioje bibliotekininkai gauna pažymą, be kurios jie negali toliau dirbti [TD3].

Kito tyrimo dalyvio nuomone, iki šiol gajus ịsitikinimas, kad „specialybės diplomo turèjimas turi užtikrinti esmines profesines žinias ir profesionalumą“ [TD8], nors, pasak tyrimo dalyvio, „tai visaip ten būna" [TD8]. Tyrimo dalyvis mano, kad turi būti sukurta kvalifikacijos kèlimo sistema. Jos pagrindas, tyrimo dalyvio nuomone, galètų būti finansinè paskata, „aišku, pinigai [darbuotojui] yra labai svarbu. [Profesionalumo vystymo sistemą reikètų] pririšti prie apmokejjimo sistemos $<\ldots$. . Atsirastų bibliotekininkystės ekspertas, metodininkas... pavyzdžiui <...> kaip ten mokyklose“ [TD8]. Šiuo metu, pasak kito tyrimo dalyvio, situacija dèl atlyginimų nèra gera („turi gaut adekvatų atlyginimą $<\ldots>$ kurie dirba daug ir yra iniciatyvūs") [TD6].

Metinis rezultatu vertinimas. Profesionalumo vertinimo pradmenis tyrimo dalyviai jžvelgia neseniai idiegtame metiniu rezultatu vertinime. Tyrimo dalyvis pritaria naujai atsiradusiam svertui: „tai žmogų motyvuoja. Tu kažkaip save perkratai ir motyvuoji. <..> 20 metų tikrai nieko nebuvo, pelkë“ [TD3]. Tobulintinas dalykas - nuo rezultatų realiai turi priklausyti atlyginimas.

Kaip sako kitas tyrimo dalyvis: „Metiniai pokalbiai motyvuoja, labai privertė pasitempt“ [TD5], juk direktorius vertina visą veiklą, o „užduočių atlikimas siejamas su finansais“ [TD5]. Vis dèlto šią naujovę reikia tobulinti, nes ,ivertinti [darbuotojus] turi iki gruodžio 31 d., o tuomet tu dar nežinai, koks bus biudžetas" [TD5]. Nežinoma, kiek bus galima skirti kintamajai darbo užmokesčio daliai, negali ir labai gerai ịvertintam darbuotojui pažadèti, kiek jis gaus didesnị atlyginimą. Nes gali būti situacija, kad tokių finansų visai nebus arba bus tiek, kiek darbuotojai sirgs, ir taip bus taupomas atlyginimo mokos fondas [TD5].

Baziniu žiniu poreikis. Tyrimo dalyvis plètoja mintị apie profesijos universitetinių studijų trūkumą („pirmiausia reikia grąžinti bibliotekininkystès studijas. Be šito tai yra... vargas ir nesąmonių rinkinys“ [TD7]). Kitas dalykas, pasak pašnekovo, „atęję iš gretutinių studijų [krypčių], [jiems] būtina suteikt bazines [profesijos] žinias. Ir trečias dalykas - [jau dirbančius bibliotekininkus] reikia mokyti modernių [informacijos ir technologijų] dalykų" [TD7].

Kitas tyrimo dalyvis pabrèžia bendro universitetinio (geriau bibliotekininkystès) išsilavinimo svarbą. Apgailestaudamas dẻl nutrūkusių Vilniaus universiteto bibliotekininkystės studijų, tyrimo dalyvis nurodo, kad tai išties kelia probleminę dilemą - o ką ịdarbinti vietoj išeinančiu (dažniausiai ị pensiją) darbuotojų? „Bazinius-sisteminius [bibliotekininkystès] dalykus tenka mokyti vietoje. Tik tas trunka ilgai - nuo 
0,5 metų iki 2 metų, kol perpranta profesijos esmę " [TD7]. Profesionalumo vystymas meistrystès keliu, kaip tai daro ne viena biblioteka, „labai ilgai užtrunka“ [TD3].

Pasak vieno tyrimo dalyvio, būtinos podiplominès ar išlyginamosios bibliotekininkystès studijos nespecialistams, „nes jiems tenka vietoje daug mokytis, kad nedarytų klaidų“ [TD5]. Šiuo metu ìdarbintam nebaigusiam studijų bibliotekininkui tenka studijuoti artimą sriti (socialinius humanitarinius mokslus) [TD5, TD1].

Kvalifikacijos kèlimo / kompetenciju tobulinimo sistema. Profesionalumo sistema suvokiama kaip kompetencijoms tobulinti skirti mokymai. Jie turètų būti organizuojami dviem kryptimis: 1) iš kitų studijų sričių atejjusiems (studijų pagrindų išdèstymas) ir 2) tęstinis dirbančių bibliotekininkų kompetencijų ugdymas (siekiant modernių kaitos tendencijų atitikimo) [TD1].

Keletas tyrimo dalyvių profesionalumo vystymo sistemą sieja su universitetinèmis studijomis ir postudijiniu kvalifikacijos kèlimu. „[Reikalingos] kažkokios specializuotos studijos, nors pusè metų. Buvo nacionalinè biblioteka su universitetu pradejjus, pagal projektą kažkokị. Mūsų baigè kelios <...>. Jos visai kitaip dirbt pradèjo. Nes vis tiek žmogui reikia baziniu žinių" [TD3]. Todèl, pasak pašnekovo, turètų būti sukurta kažkokia bazinių žinių sistema, kurios pagrindu nespecialistai turètų išlaikyti profesinị egzaminą: „Tai gali būt žmogus baigęs bile ką, svarbu, kad jis išlaikys tą egzaminą“ [TD3]. Ir tai būtų kaip sertifikavimo sistema, ji tikrai reikalinga: „Sertifikavimo reikia. Žiūrèkit, inžinieriai, tai <...> statybos priežiūros negausi, turi statybininkų asociacijoj išlaikyt egzaminą ir gaut licenciją <...>. Tai panaši turètų būti ir bibliotekininkų profesionalumo reikalavimų sistema" [TD3].

Kitas tyrimo dalyvis mano, kad dabartinëje kvalifikacijos kèlimo sistemoje „trūksta <...> aukščiausios grandies, kuri su specialistais dirbtų“ [TD9]. Pasak pašnekovo, Nacionalinẻ biblioteka turètų būti ir metodinis centras, kiekvienoje iš profesinių veiklų tęstiniu būdu suburiantis specialistus. „Kvalifikacija nèra tik <...> išdėstoma medžiaga. Tai yra specialistų tarpusavio bendravimas" [TD9]. Labai svarbu, kad i vieną vietą suvažiuotų specialistai, jie kartu aptartų kylančias problemas, gautų aukščiausios kategorijos specialistų konsultacijas („Visai kita kompetencija, kai mokosi Nacionalinejj bibliotekoj. <...> Juk matom, kad apskrities bibliotekos specialistai $<\ldots>$ nèra daug kvalifikuotesni negu viešosios bibliotekos specialistai, o jau Nacionalinèj, tai mes žinom <....> kad tai yra visos Lietuvos mastu <...>. Tai yra daug aiškiau“ [TD9]). Tyrimo dalyvis kvalifikacijos sistemos nebuvimą įvardija skaudžiausia vieta ir labai didele problema. Pasak pašnekovo, „buvo paruošta kvalifikacinè sistema, bet jinai buvo nepritaikyta. Kultūros centrai pritaikè. <...> Turètų būti [ir bibliotekose], turètų priklausyti nuo to, kiek žmogus kèlè kvalifikaciją, kiek jisai turi kompetencijų ir kaip jis tas kompetencijas panaudoja“ [TD9].

Esamoje kvalifikacijos kèlimo situacijoje, pasak vieno tyrimo dalyvio, problema yra pats organizavimas, kuris vyksta projektiniu būdu. Pasak pašnekovo, „kas projektą parengia, o kas ir ne“ [TD5]. Parengus aktualią temą, biblioteka gali išleisti ị mokymus vieną, daugiausia du asmenis (nes tiek vietų skiria organizatoriai), o taip neturi būti.

Negerai dabartinejje kompetencijų ugdymo sistemoje yra siūlomų kursų chaotiškumas, nenuoseklumas, pasak tyrimo dalyvio, „nutveriau, ką pagavau“ [TD3]. Nespecialistai dažnai gali pradèti kelti kvalifikaciją nuo specifinių kursų, kuriuose „plaukioja“, nes nesupranta daugelio esminių terminų, sąvokų. Tyrimo dalyvio nuomone, kvalifikacijos kèlimo kursai turètų būti organizuojami išvykoje, dideliame mieste. „Juk, būdavo, iš mažų rajonų išvyksta žmonès ị Vilnių, aplanko kultūrinius renginius, nueina i muziejus. Tai yra labai svarbu" [TD3].

Kita vertus, pasak tyrimo dalyvio, tai, kad dabartinè kvalifikacijos kèlimo sistema apima ne tik Nacionalinę, bet ir regionines bibliotekas, yra gerai. „Dabartinè sistema puiki $<\ldots$. . Nes mokymai regioninėse bibliotekose yra lengviau pasiekiami (darbuotojai gali tą pačią dieną nuvykti ir grịžti, jei susidaro grupe specialistai atvyksta į vietą). Trūkumas - per menkas temų pasirinkimas. Pasak tyrimo dalyvio, „poreikius rašom, teigiam, kad toks poreikis yra, bet to nebegaunam“ [TD5]. Kito tyrimo dalyvio nuomone, dabartinè mokymų sistema yra gera: „mes nuolat rengiam mokymus. Jei tik matom, kad kažko trūksta, 
visada pasiūlomi mokymai“ [TD1]. Puikias galimybes mokytis, pasak tyrimo dalyvio, sudaro apskrities biblioteka. „Galima siųsti darbuotojus i stažuotes, kursai, mokymai, nuotoliniai mokymai, atvažiuoja specialistai ị vietą" [TD1].

Kitas tyrimo dalyvis sako, kad profesionalumo lygị kelti dabar nori dauguma darbuotojų, o to anksčiau nebuvo: „Dabar ir tų kursų rečiau, ir negali siųsti po 10, kaip anksčiau, dabar tik 2-3<...>. Visi nori, ir tenka argumentuoti, kam labiausiai reikia" [TD2].

Vienas iš tyrimo dalyvių mano, kad dabartinè kvalifikacijos kèlimo situacija turi akivaizdžiu trūkumų: mokymus rengia [pagal projektus] gavę finansavimą, o jis paprastai būna mažas. Todèl dažniausiai kviečiami lektoriai pagal rengusios projektą bibliotekos poreikius ir pirmiausia ten dalyvauja savi darbuotojai („Nepakanka nei mokymų, nei kokybès“ [TD10]). Todèl tyrimo dalyvis mano, kad turètų būti kuriamas vienas kompetencijų ugdymo centras (ar keletas jų), nesusietas su apskričių bibliotekomis. Pats pašnekovas dalyvavo Kultūros darbuotojų tobulinimosi centro surengtuose mokymuose, skirtuose nespecialistams, ir liko labai patenkintas („berods trijų savaičių mokymai ne bibliotekininkams. Tobula tiesiog“ [TD10]).

Kita vertus, „daugelị išsilavinimo spragų bibliotekininkai gali panaikinti patys, juk bibliotekoje informacijos apstu“ [TD1]. Kitas tyrimo dalyvis mano, kad vienas iš profesionalumo palaikymo kelių - meistrystė: „Mes ant tų dar, žinot, seniokų, laikomès. Tai tarsi meistrystë“ [TD3]. Tačiau pašnekovai pastebi, kad tai ilgai užtrunka.

Sistemos kūrimas - atsakinga, ilgalaikè veikla. Vienas tyrimo dalyvis argumentuoja: kompetenciju ugdymo sistemoje pradèti reikètų nuo strategijos, ịvardyti tikslą, numatyti tikslus. „Nes specialistai kaip ir nyksta po truputi $\langle\ldots\rangle$. Ateina iš kitų specialybių. Bet jis tada turi praeiti būtent tą pagrindą, tą mokymą $<\ldots>$. Kažkokia tai institucija [tai turi daryti], kurią reikia sukurti $<\ldots>$. Gerai reiktų apie tai pagalvoti ir kalbèti $<\ldots>$ Ir kažkas turi imtis iniciatyvos, turètų pasiūlyti tą koncepciją < ... $>$. Šiuo atveju aš tikrai žiūrèčiau i nacionalinès bibliotekos žmones, specialistus $<\ldots .$. . Nes jeigu tai nepadarys specialistai, tai padarys kiti, ir kažin, ar specialistai tuo bus patenkinti. Kad neatsitiktų taip, kad specialistai išnyks $<\ldots>$. Ir tai ne tik apie naujai rengiamų specialistų problemą kalbame, o ir apie esamų specialistų kvalifikacijos kèlimą. Išsilavinimas yra labai svarbus <...> Kas dabar kvalifikuos tuos bibliotekininkus?“ [TD6].

Vienas iš tyrimo dalyvių mano, kad profesionaliems bibliotekininkams grèsmès kyla dèl to, kad nèra bendros politikos: „nieko nedarant dèl bibliotekininkų kvalifikacijos kèlimo sistemos, praejus kažkiek metų bus labai didelè problema, kaip su spaudinių komplektavimu. Kai sumažino drastiškai [finansus] ir liko tuščia erdvė fonduose, taip gali atsirasti vakuumas ir žmogiškuosiuose ištekliuose $<\ldots>$. Juk $<\ldots>$ sugriauta kvalifikacijos kèlimo sistema Lietuvoje ir po šiandien dienai ji nèra atstatyta" [TD4]. Pasak tyrimo dalyvio, „didžiausia klaida, kad buvo sugriauta kvalifikacijos kèlimo sistema ir nesukurta niekas, jokio analogo“ [TD4]. Svarstydamas apie tai, kokia ta sistema turètų būti, pašnekovas mano: „jeigu nekinta $<\ldots>$ dabartinè Lietuvos bibliotekų sistema, tai analogiška turètų būti ir kvalifikacijos kèlimo sistema. Aš nežinau, kur galètų kvalifikaciją kelti Nacionalinès [bibliotekos darbuotojai], bet apskričių bibliotekos personalas turètų kelti arba Nacionalinèje bibliotekoje, arba čia, pas save su Nacionalinès bibliotekos žmonèmis. Aš tikiu, kad [Nacionalinejje bibliotekoje] - aukščiausios kvalifikacijos žmonès, kad jų mąstymas ir suvokimas, ir supratimas yra nacionalinio lygio. <..> Apskričių bibliotekos bibliotekininkai turètumėm apmokyti arba rengti metodikas savo [regiono] savivaldybèms, o jos - savo filialams" [TD4].

Finansai profesionalumo skatinimo sistemoje. Vienas iš svarbių profesionalumo sistemos elementų, tyrimo dalyvio nuomone, kvalifikacijos kèlimas ir profesionalaus darbo susiejimas su darbuotojų finansiniu skatinimu ir poreikiu, kad kvalifikacijos kèlimas bütu finansuojamas iš biudžeto, taip sudarant sąlygas kelti kvalifikaciją pagal poreikius.

Tyrimo dalyvis tvirtai įsitikinęs: „kvalifikacijos kèlimui turi būti biudžete numatytos lèšos, tikslinès, taip, kaip yra fondų komplektavimui. Ir taškas, ir nekvestionuojama. O taip nèra" [TD4]. Pasak kito pašnekovo, noras ugdyti kompetencijas bibliotekai tampa iššǔkiu - nors abstrakčiai visi už kompetencijų 
ugdymą, tai riboja finansai ir siūlomas pasirinkimas [TD7]. Kitas tyrimo dalyvis mano, kad profesionalumo tobulinimas kainuoja, o rajoninių bibliotekų biudžetai mažẻja, nes mažèja gyventojų skaičius. Tai turi itakos atlyginimams, priedams, lemia nelanksčią apmokẻjimo sistemą. („Dabar mes po biškį visiems dalijam. A ir B lygis, ir tu negali iššokt. O priedų kaip ir nėra. Gyventojų mažèja, biudžetai mažèja " [TD3]).

Kad būtų reali profesionalumą skatinanti sistema, kaip sako kitas tyrimo dalyvis, turi atsirasti konkurencijos elementų, turi būti sureguliuotas ir apmokẻjimas už veiklas. Anksčiau to paties tyrimo dalyvio minèta bibliotekos personalo struktūra detalizuojama taip: „bibliotekoje turi būti 7 labai aukšto lygio bibliotekininkai ir 10 kitų aukšto lygio bibliotekininkų, kuriuos konsultuotų tie septyni. <...> Tie du lygiai turi būti gerai apmokami. Tada bus rezultatas" [TD3].

Kitas tyrimo dalyvis pabrèžia, kad vienas iš skaudžiausių elementų kompetencijų sistemoje yra tas, kad atlyginimas už darbą neatspindi įdirbio: „gauna algą tą pačią, kuris nieko nedaro, ir tas, kuris turi tris projektus" $<\ldots>$. Bibliotekininkai $<\ldots>$ kurie gerai dirba, turi ir uždirbt gerai“ [TD9].

Norą skatinti gerai dirbančius, profesionalius darbuotojus, pasak tyrimo dalyvio, riboja minimalus atlyginimų fondas. Be to, pašnekovas išsako nuoskaudą, kad skirtingose vietovėse ir atlyginimų dydis, ir galimi priedai už gerą darbą netolygūs. „Čia turètų būti išdirbtas tam tikras mechanizmas <...>. Dabar žmonès, dirbantys tą patị darbą skirtingose vietose, labai skirtingą gauna atlygi $<\ldots>$. Tai nèra teisinga žmonių atžvilgiu“ [TD6]. Pasak kito tyrimo dalyvio: „Dabartinè kintama atlyginimo dalis yra per maža, labai suvaržyta <...>", kol kas nepasiteisina [TD9]. Konkrečiu atveju kintamosios dalies dydis, skiriamas savivaldybès, sudaro 5 proc. atlyginimo, tyrimo dalyvis teigia, kad atskaičius mokesčius tai yra apie 20 eurų.

Vienas iš tyrimo dalyvių mano, kad kintamoji atlyginimo dalis dirbant bibliotekoje turi būti surenkama balais, už atliktus papildomus darbus „bendroji dalis plius priedas $<\ldots .>$ už kvalifikaciją, <...>, jeigu projektus vykdo“ [TD9]. Dabar vertinimas vyksta pagal metų pradžioje suformuotą užduotị, o tai, tyrimo dalyvio nuomone, netikslu. Pavyzdžiui, „formuodamas užduotį negali nurodyti, kad turi vykdyt 3 projektus. $<\ldots>$ O jeigu negavo finansavimo $<\ldots . .>$, nors puikiai parašè?“ [TD9]. Taigi, užduotis formuojama aptakiai, netiksliai, todèl ir vertinimas vyksta panašiai.

Vieno tyrimo dalyvio nuomone skiriasi: „stebėdama atskirus atvejus aš galvoju, kad net pinigai nèra pakankama motyvacija. Nes yra žmonių, kurių tu nesumotyvuosi. Jokiais pinigais, nei padidintais, nei sumažintais" [TD10]. Neseniai įteisinta atlyginimu sistema su kintamaja dalimi yra bandymas tokią sistemą sukurti, tačiau konkrečios bibliotekos patirtis šioje srityje nėra pavyzdinė. Pasak tyrimo dalyvio, „teorijoje aš sutinku, praktikoj aš nežinau, kaip tai veiks $\langle\ldots$. . Tai priklauso nuo ekonominés situacijos, jeigu atlyginimų pagrindinẻ dalis padengtų būtinuosius darbuotojų poreikius, tai veiktų. O dabar... yra daugiau baimès ir nepasitenkinimo nei motyvacijos daugiau ar geriau dirbti“ [TD10]. Šiuo metu iš savivaldos gauti priedai buvo paskirstyti tolygiai visiems, didelį nepasitenkinimą žmonès reiške dẻl to, kad kintamoji dalis antraisiais metais sumažejo. Kol kas šis tyrimo dalyvis negalvoja apie darbo kokybès, profesionalumo sąsajas su veiklos vertinimu ir kintamąja atlyginimo dalimi. Jis daugiau nuogąstauja, kas bus, jei sumažejęs atlygis sukels neigiamas darbuotojų emocijas, todèl šiuo metu pertvarkos ir profesionalumo siekiai vyksta, kai „rausiuosi iš apačios ị viršų, kuriu santykius su skyrių darbuotojais, vedèjais“ [TD10]. Nes viena iš pamatinių vertybių, pašnekovui kuriant kolektyvą, yra „žmogiškumas <...>. [O] minimalus atlygis <...> neleidžia būti žmogui oriu“ [TD10]. Tyrimo dalyvis pasiremia A. Maslow piramide. Jo teigimu, kol ekonominè situacija tokia, kad bibliotekininku atlyginimai neužtikrina oraus žmogaus fiziologiniu ir saugumo poreikių, jis negali atsipalaiduoti ir tapti kūrybingas („pirmiausia turi būti tie pagrindiniai poreikiai patenkinti, kad žmogus būtų ramus dèl <...> savo kasdienio gyvenimo“ [TD10]). Prisimenamas bendras nesaugumo jausmas darbe, kai „tu gyveni baimèj. Ir tu lauki, kad iš viso gautum atlyginimą" [TD10]. Tai susiję su neseniai išgyventa buhalterinès apskaitos sistemos keitimo patirtimi, kurią pradèta vykdyti visai nepasirengus.

Kito tyrimo dalyvio manymu, jeigu būtų didesni darbo užmokesčio fondai, reikètų kurti bibliotekininkų motyvacijos sistemą, kurioje „kvalifikacijos kèlimo dalykai būtų <...> naudingesni pačiam 
bibliotekininkui“ [TD6]. Suprantama, labai svarbu žmogų skatinti ir moraliai: „gražu <...> moralinè motyvacija $\langle\ldots\rangle$, nepamiršti žmogų pagirti, padèkoti jam už gerus darbus. Taip ir stengiamès daryti $<\ldots>$. [Dabar labai svarbu] kad tie koeficientai būtų pagerinti <...> kultūros darbuotojams“" [TD6].

\subsubsection{Profesijos neapibrëžtumas}

Vienas tyrimo dalyvis išreiške abejonę dèl bibliotekininko profesinio tapatumo: „Nežinau, ar bèra dabar profesija? <...> O kas gi dabar tas bibliotekininkas? Aš gi nemačiau jo tikro“ [TD3]. Kita vertus, pašnekovas yra už bibliotekines studijas, mato tokių studijų itaką bibliotekų kokybei: „Aš taip galvoju: kur yra bibliotekininkų studijos, ten ir bibliotekos yra labai geros" [TD3]. Jis pritaria intencijai saugoti profesijos statusą: „Juk visos profesijos saugo savo profesiją. Tik mes kažkaip tai paleidom velniop“ [TD3]. Profesiniam identitetui turi įtakos tai, kad naujai įdarbinami darbuotojai nèra specialistai: „Kurie ilgai dirba, dažniausiai turi bibliotekinị išsilavinimą, bet ị jų vietas dabar ateina dažniausiai pedagogai“ [TD3], todèl nacionaliniu lygmeniu būtina sudaryti „kompetencijų rinkinị, sudarytą iš kelių lygių, apimanti bibliotekininko profesijos išskirtinumą" [TD3].

Profesionalumo sistemos pagrindą vienas tyrimo dalyvis mato bazinėse universitetinėse bibliotekininkystės studijose („visų kitų kompetencijų mes galim prisižebravot. Bẻda $<\ldots .>$, kad mūsų specialybès nèra" [TD7]). Pašnekovo teigimu, universitetinès studijos užtikrina krypties tęstinuma, suteikia pagrinda profesiniam tobulëjimui. Yra reali grèsmè, kad „knygoms bibliotekoj vietos neliks. Yra visokių pas mus „inovatorių“ [TD7]. Pabrèždamas sisteminio mąstymo svarbą organizuojant bibliotekos darbą, tyrimo dalyvis mato grèsmę profesijos išlikimui. Grèsmè pasireiškia per: 1) nepakankamą darbuotojų finansini skatinimą už rezultatus ir 2) artejjančią Vilniaus universiteto studijas baigusių bibliotekų direktorių kaitą, kai jų vietas gali užimti perẻjūnai [TD7].

\subsubsection{Profesionalumo vystymas}

Temoje Profesionalumo vystymas išskirtos trys potemès: 1) poreikis ir sąlygos kompetencijoms tobulinti; 2) bibliotekose vykstantys kompetencijų tobulinimo būdai ir 3) tyrimo metu vadovų matomas poreikis ugdyti kompetencijas (jas išvardijant).

\subsection{Priežastys ir salygos vystyti profesionaluma}

Tyrimo dalyviams nekèlè abejonių poreikis turèti bibliotekoje profesionalius darbuotojus. Pasak vieno pašnekovo, tai siejasi su nuolat vykstančiais pokyčiais, $\mathfrak{i}$ kuriuos biblioteka turi žiūrèti kaip ị iššūkius keisti biblioteką ir nuolat išlikti patraukliems visuomenei [TD6]. Kito tyrimo dalyvio žodžiais, bibliotekoje dirba „išsilavinę žmonès, bet mes vis norim tas kompetencijas vystyti, vis kelti ir kelti <...> [nes] bibliotekos prestižas labai išaugo <...>. Atsirado galimybių leist bibliotekai nepasenti, būti patraukliai ir vat, atsirado poreikis turèti daug geresnị specialistą" [TD3]. Pasak kito pašnekovo, keičiantis aplinkai, esminis administracijos pageidavimas darbuotojams „[asmeninis] noras įsisavint naujoves“ [TD1].

Kitas tyrimo dalyvis mąsto: labai svarbi prielaida kompetencijų ugdymui, ,jei yra, kas užveda, o kiti bent nesipriešina ir apsijungia <...>. Tada yra kažkokių galimybių vystytis“ [TD7]. Esminė prielaida visų bibliotekininkų profesiniam tobulejimui, tyrimo dalyvio nuomone, lyderiavimas. Pasak pašnekovo, profesionalumui tobulinti reikia nuolat galvoti apie naujovių ịvedimą, jų išankstinį puoselèjimą (percituojama prof. A. Glosiené - reikia ne tik kirpti avelei vilną šiandien, bet ir slapta auginti arkliuką, kurị atėjus laikui galètum pademonstruoti kaip žirgą). Tyrimo dalyvio žodžiais: „Pokyčiai turi būti ịvedami taip $<\ldots>$ po truputi, juos neforsuot, jiems reikia ruoštis“ [TD7].

Vienas tyrimo dalyvis mąsto: „Aš labai gerbiu savo darbuotojus, tuos, kurie iš savęs nori tobulèti <...>. Paskutinius gal trejetą metų pastebiu, kad visi nori kelti kvalifikaciją“ [TD2]. Taip buvo toli gražu ne visada. Kito tyrimo dalyvio žodžiais, didžiausia kompetencijų ugdymo problema yra noro neturẻjimas arba savo problemos nesuvokimas, „,nulemtas paties žmogaus savybių“ [TD1]. 


\subsection{Kompetenciju tobulinimo būdai}

Tyrimo dalyviai kalbėjo apie tai, kaip šiuo metu bibliotekos darbuotojai tobulina darbui reikalingas kompetencijas. Bibliotekoje tikslingai gerinami technologijų naudojimo ịgūdžiai - dažniausiai pačiu bibliotekoje organizuojamuose mokymuose. Pašnekovė išskiria dvi esmines mokymų kryptis: technologinio raštingumo mokymai darbuotojams ir skaitytojams. Kad tai vyktų, reikia nuolat sekti ir žinoti realius bendruomenès poreikius ir jų pagrindu vesti mokymus: „Uodžiam, kas nauja vyksta, tai to mokomès ir diegiam $<\ldots . .>$. Darbuotojai turi ịsisavint ir išmokt, tada taikyt tuos dalykus [perduoti juos savo skaitytojams]“ [TD3]. Per laiką igyta mokymu ir konsultavimo patirtis: „wyresniems žmonėms [konsultacijos vyksta] viens prie vieno. Grupinis mokymas vyresniems žmonèms visiškai netinka. Neefektyvu visai“ [TD3].

Kitas tyrimo dalyvis apie bibliotekos darbuotojų kompetencijų tobulinimą kalba taip: kai kurias būtinas specialybei kompetencijas bibliotekininkai tobulina pačioje bibliotekoje. Tai vyksta perduodant igūdžius ir su tuo susijusias vertybes tarpusavyje, siunčiant pavienius darbuotojus ị kursus. Susiformavęs bibliotekos kolektyvas išlieka ilgą laiką stabilus, nes daugelis kartkartėmis mokosi, tobulina žinias ir igūdžius. Pavyzdžiui, informacinių technologijų specialistas perteikia reikalingus igūdžius bibliotekininkams. Išmokę bibliotekininkai pamoko kitus, taip pat ir lankytojus. Kaip ir kiekviename kolektyve, pasak pašnekovès, „yra, kurie aktyvūs <...>, kiti - vykdytojai, tai yra natūralu. <...>. Svarbu, kad būtų tas komandinis darbas bibliotekoje“ [TD6].

Tyrimo dalyvis kalba, kad ịdarbintas naujas darbuotojas siunčiamas ị centrinę biblioteką ir ten mènesị vyksta perkvalifikavimas, mokomasi „bibliotekinių pradinių pradmenų“ [TD9]. Darbuotojas mokosi „visus bibliotekinius dokumentinius dalykus. Tai fondo apsaugos nuostatai $<\ldots .$. , katalogų tvarkymas ir visa kita“ [TD2]. Savarankiškai asmuo dirbti nepradeda, kol nebaigia šių mokymų. Taip pat vyksta mokymai apskrities bibliotekoje, ten galima „bendrųjų gebẻjimų pasimokyti“ [TD9].

Vienas tyrimo dalyvis dalijasi mintimis apie tai, kad daugiausia demesio skiriama naujų darbuotoju adaptacijai. Tam taikomas iggudusio specialisto stebejjimas, konsultacijos. „Kartais nuvažiuojam ị vietą [filialuose], perduodant pareigas, kokią savaitę padirba kartu su buvusia darbuotoja" [TD5]. Bibliotekoje naudingas ịgūdžių perèmimas dirbant kitokị, bet susijusị darbą. Pavyzdžiui, ị pensiją išèjusią komplektuotoją pakeitė LIBIS sistemos administratorè. Kaip sako pašnekovas, ,ji yra inžinierė, bibliotekoje IT specialiste dirbo ilgai, kūrè tą sistemą ir taip daug išmoko. Ji perèmè pareigas puikiai, be problemü“ [TD5].

Realijos tokios, kad igūdžiai dažniausiai ugdomi iš projektų: „perkam ịrangą ir būna mokymai šalia“ [TD3]. Kitas tyrimo dalyvis mano: nors mokymai vyksta, jų nepakanka. Reikia pagalvoti apie įvairias mokymo formas (pavyzdžiui, vaizdo mokymams reikia ir konsultavimo funkcijos). Pasak pašnekovo: „Gaunasi, kad yra duodamos galimybès, bet plaukt reikia išmokti pačiam“ [TD5].

Vienas tyrimo dalyvis akcentuoja, kad esminis profesionalumo vystymas vyko per didžiuosius $j$ bibliotekas nukreiptus projektus, ypač - B. ir M. Gatesų fondo lěšomis. „Biblioteka teikè parašką ir gavo du milijonus litų, kad <...> galètume apmokyti visus apskričių darbuotojus. Ir jūs ịsivaizduojat, du milijonai litų, tai fantastiški pinigai. Ir kẻlèm kvalifikaciją ne tik savo profesinę, bet [lavinom] ir ịvairias kitas [bendrąsias] kompetencijas“ [TD4]. Dabar projektiniu finansavimu paremtų mokymų nepakanka, „šiandien mūsiškiai [viešųjų bibliotekų darbuotojai - aut. past.] pas jus [Nacionalinėje bibliotekoje - aut. past.] retai mokosi arba nesimoko. Mūsiškiai gal kažkiek [pamoko], stengiamès iš projektinių lèšu, kas yra absoliučiai neteisinga mokyme“ [TD4]. Organizuojami mokymai turètų būti orientuojami ị ịvairaus lygio specialistus, turètų būti ir bendrųjų dalykų mokymai. Pasak pašnekovo, „didžioji dalis ir dabar yra skirta vidiniams mokymams. Tai visada yra norinčių kelt kvalifikaciją " [TD4]. Organizuoti išorinius mokymus dažnai neužtenka lèšų. Kita vertus, tyrimo dalyvis pastebi, kad ne visas igytas kompetencijas bibliotekininkai panaudoja („turi panaudoti savo potencialą < ...>. Yra pakankamai apmokyti, pakankamai kvalifikaciją kèlè ir keliantys <...> [o] nèra svertų, kaip darbuotoją motyvuot taikyti kompetencijas“ [TD4]). 
Pavyzdžiui, kalbų vartojimo tobulinimas yra individualus kiekvieno reikalas: „tu žmogaus nepriversi, jeigu jis darbe nenaudoja užsienio kalbos“ [TD4].

Pašnekovo nuomone, bibliotekos darbuotojai išsilavina savaime, atlikdami pareigas („čia tokia vieta, kur tu vis tiek išsilavini. Net ir nenorėdamas. <...>. Išsilavini ir tau pasidaro ịdomus tas darbas“ [TD3]). Pasak kito pašnekovo, profesionalumo kaita vyksta nuolat: „žmogus pasimoko, pamato ir pritaiko" [TD2].

Technologinio raštingumo ịgūdžiai ugdomi savišvietos būdu: „Savišvieta. Kapstomės patys, nes negalim nesąmonių daryt, nes nieks neateis“ [TD3]. Pasak kito tyrimo dalyvio, nemažai dalykų bibliotekininkai patys išmoksta. Pavyzdžiui, „kurie domisi robotika, tai jie tikrai pasidomi, ir kaip reikiant <...>. Nustembi, kad žmogus būna tiek pasiskaitęs ir pasidomèjęs" [TD8]. Kitas tyrimo dalyvis pabrèžia, kad „išmokti galima visko“ [TD10]. Pačiam pašnekovui teko kolektyvą nuo pagrindų mokyti elementarių kompiuterinio raštingumo dalykų (pavyzdžiui, naudotis elektroniniu paštu), todẻl jis mano, kad tokios kompetencijos gali būti skleidžiamos ir perimamos pačiame kolektyve. O specifinių informacinių technologijų dalykų, skirtų atskiroms paslaugoms, kaip antai „,virtualios realybės akiniai, robotukai, planšetės ir kiti specifiniai dalykai, yra ne visiems" [TD10]. Pasak pašnekovo, entuziastai juos išmoksta per projektinius ar kitokius mokymus ir to pakanka.

Tyrimo dalyvio nuomone, kolektyvo profesionalumą ugdo ịsilieję tarptautiniai savanoriai [TD3]. Kitas tyrimo dalyvis kalba, kad atvykstantys savanoriai savo veikla „padeda mums, bibliotekininkams, kažką naujo ir pozityvaus parodyti“ [TD6]. Tarkim, ukrainietė yra anglų kalbos mokytoja, ir bibliotekininkai sukūrẻ paslaugą vaikams „Aš noriu mokytis anglų kalbos“. Vasarą per žaidimus savanorė moko kalbos igūdžių, klube gali dalyvauti ir vietos gyventojai, ir atvykę vasaroti. Savanoris iš Armėnijos analogišku pagrindu veda užsièmimus „Aš noriu piešti“ [TD6].

Kai kurie darbuotojai mokosi nuotoliniu ar tęstiniu būdu savarankiškai, yra baigusių kolegijas [TD9]. Kitas pašnekovas sako, kad neturintys profesinio išsilavinimo skatinami baigti bibliotekines studijas formaliu būdu („bent keturi darbuotojai baigè kolegijoje šalia administracinių ir tas, susietas su biblioteka“) [TD2].

\subsection{Reikiamu ugdyti kompetenciju ịvardijimas}

Kalbėdami apie bibliotekininkams tyrimo metu aktualias tobulinti kompetencijas, tyrimo dalyviai mini bendruosius igūdžius, profesinèje veikloje reikalingas atsinaujinančias žinias ir naujus igūdžius, ypač teikiant inovatyvias, anksčiau bibliotekoms mažai būdingas ar visai neteiktas paslaugas.

Sritys, kuriose personalui būtina tobulinti kompetencijas: 1) naujos literatūros vertinimas ir 2) LIBIS sistemos taikymas - šie mokymai, pasak pašnekovo, bibliotekininkams privalomi („Nori - nenori, turi mokytis, nes neveiks sistema “ [TD3]). O apie naują literatūrą, kaip sako tyrimo dalyvis, norètųsi pasimokyti, kad tai būtų „paskaitos, tokia kaip ir Knygų mugès patirtis praktikoj. Naujausių knygų pristatymai, literatūros vertinimas" [TD3]. Pašnekovas apgailestauja, kad tokiems mokymams biblioteka ne visada gauna finansavimą, o ,veltui geros žinios nedalinamos“ [TD3].

Kitas tyrimo dalyvis mano, kad dažniausiai darbuotojams trūksta bendrųjų igūdžių, „dalykinių žinių, ypač kur vyresnès darbuotojos, seniai dirba, jos turi“ [TD1]. Administracijos siekis - ugdyti darbuotojų kultūros poreikị, norą dalyvauti joje, pažinti geruosius pavyzdžius. Pašnekovas teigia, kad pasigendama šių esminių kompetencijų: lankstumo, viešo kalbëjimo baimès [baimès nebuvimo], komunikacijos gebèjimų, kompiuterinio raštingumo, gebejjimų pritraukti skaitytojus (lankytojus) [TD1].

Tyrimo dalyvis nurodo būtinas bibliotekininkams gerinti kompetencijas: 1) gerinti užsienio kalbų igūdžius („kurie mokyklas baigė Brežnevo laikais <...> jų užsienio kalbos žinios gerokai menkesnès“ [TD7]); 2) plèsti technologinị raštingumą, ịvaldant naująsias medijas; 3) perteikti esmines profesijos žinias įdarbintiems nespecialistams („,kad suprastų, kas yra biblioteka. Dél ko viskas daroma - kad susivokti. <...> Kas yra UDK ?<..> Kas kur guli ir kodèl“ [TD7]). 
Tyrimo dalyvio nuomone, ịsidarbinusiems nespecialistams trūksta veiklai būtinų žinių, pavyzdžiui, apie literatūrą, vaikų literatūrą, populiariausius rašytojus ir panašiai. Reikalingi tokių temų mokymai. Trūksta ir bendrųjų gebẻjimų, nes ateinantiems dirbti, kad ir turintiems aukštąji išsilavinimą, trūksta raštvedybos, kompiuterinio raštingumo (jis vis kinta), tekstų rašymo igūdžių. Darbuotojams reikètų bendrųjų kompetencijų ugdymo - mokymų, skirtų motyvacijai didinti: „rašyt projektus, gaut lèšas, juos laimèt“ [TD9]. Kita vertus, motyvaciją imtis šių veiklų sudarytų galimybė tuo pasididinti atlyginimą [TD9]. Tyrimo dalyve pabrèžia, kad išskirtinai trūksta kvalifikacijos kèlimo galimybių bibliotekoje dirbantiems ilgamečiams specialistams („Didžiausios problemos yra su specialistais <...>. Pavyzdžiui, pamatèm duobę ar atotrūkị dirbant su UDK" [TD9]). İvyksta globalūs pokyčiai, ir nors šalyje yra parengta metodika, rajonų specialistai nori turèti mokymus nacionalinèje bibliotekoje. Tas pats pasakytina ir apie LIBIS sistemos pokyčius ir iš to kylančias problemas [TD9].

Kitas tyrimo dalyvis kalba, kad svarbi kompetencijų tobulinimo dalis turi būti skirta bendruomenès švietimui, informavimui apie pasikeitusias bibliotekos funkcijas, naujas veiklas. Pateikiamas pavyzdys: „suomiai, viešųų bibliotekų avangardas, sako, - mes irgi turim sakyt, ką mes darom. Nes vat gaji tokia nuomonè, kad biblioteka yra vien tiktai [knygų] lentyna" [TD8]. Pirmiausia, pasak tyrimo dalyvio, reikia tobulinti „,bendražmogiškas [savybes], tuos gebèjimus komunikacinius, kultūrinius $<\ldots .>$, kalbų mokèjimą. Labai svarbu personalui tiesiog atnaujinti profesines žinias „naujų sužinot dalykų apie $<\ldots>$ bibliotekininkystès tendencijas pasaulines $<\ldots . .>$. Kokia bibliotekų ateitis, vizija ir visa kita $<\ldots>$. Labiausiai reikètų motyvacijos kažkokios. Ir tada profesionalumas automatiškai šokteltų“ [TD8]. Reikia pakelti bendrajj kultūrini lygị, kad didžiausia veiklos problema netaptų skaitytojų skundai apie tai, kad „kabinete riejasi susėdusios trys <...> “TD3]. Reikètų organizuoti konfliktų valdymo, motyvacijos mokymus („smegenų plovimo“ (juokiasi) kursai reikalingi. Kad suvoktų, kam jiems to reikia [dirbti dèl profesinio pasitenkinimo] “ [TD8]).

Kitas tyrimo dalyvis mano, kad reikalingi tęstiniai, pakopomis igūdžius gerinantys mokymai, skirti informacinèms technologijoms ịvaldyti, psichologijai pažinti, konfliktiškoms situacijoms valdyti. Pašnekovo nuomone, problema yra vèluojantys dalykinių žinių ir igūdžių mokymai (pavyzdžiui, UDK pakeitimai ir su tuo susijusi veikla; statistikos formos pildymas) [TD5].

Pasak kito pašnekovo, bibliotekininkams reikètų lavinti edukatoriaus igūdžius, nes tokių veiklų anksčiau bibliotekininkai nevykdè. „Kaip knygą pristatyti, kaip vaikui pristatyti, kad jis pradètų nuo knygutès su trim žodžiais ir paveiksliuku iki klasikos. <...> Ir dèl suaugusių <...> grupinio mokymo įgūdžių “ [TD10]. Kito pašnekovo nuomone, šiuo metu jaučiamas darbuotojų nepasirengimas mokyti kitus, edukacinių kompetencijų reikètų pasisemti daugiau, nes mokymai tampa ịprasta veikla bibliotekininkams [TD4].

Trūksta žinių ir igūdžių, kaip dirbti su tikslinėmis grupèmis - neigaliais žmonėmis, turinčiais specialiụjų poreikių („biblioteka atsiveria naujoms tikslinèms grupėms ir bibliotekininkams trūksta žinių, <...> kaip aptarnauti tokius lankytojus, kaip su jais elgtis?" [TD10]). Reikalingi tęstiniai mokymai, skirti rašto kultūrai, tiesiog komunikacijos raštu etikai, normoms, tinkamam „Word“ paketo naudojimui [TD10].

Tyrimo dalyvis pažymi, kad labiausiai pageidaujami yra psichologijos srities, bendravimo igūdžiu lavinimo kursai, nes tai panaudojama komunikacijoje su skaitytojais. Reikètų tobulinti projektų rašymą, gilintis ị kitų šalių bibliotekų patirtị, mokytis kalbų. Visa tai, kas sudaro galimybes „kažką keisti bibliotekoj, kad neužsistoveti“ [TD2]. Kita vertus, kompetencijos nuolat kinta, kaip ir pačios veiklos bibliotekoje. Todel tyrimo dalyvis mano, kad „[bibliotekininkams] kompetencijos reikalingos $<\ldots>$ bus tokios, kokia veikla atsiras bibliotekoj. Labai nauja“ [TD2].

Labai svarbu bibliotekininkams gerinti komandinio darbo igūdžius. Bibliotekininkams ypač reikia tobulinti informacinių technologijụ igūdžius. Trūksta mokymų apie literatūrą, „kad bibliotekininkas geriau susigaudytų šitos literatūros jūroj" [TD6], reikètų tokios pagalbos iš literatūrologų, profesionalų. Reikia psichologijos, socialinès integracijos srities mokymų. „Kaip atpažinti nuskriaustą vaiką? <...>, kaip tam žmogui galbūt padèti, ką rekomenduoti paskaityti ir t. t. Kaip komunikuoti su skirtingų socialinių sluoksnių grupèmis, lankytojais ir t. t.“ [TD6]. 


\section{Apibendrinimas ir diskusija}

Atliktas kokybinis tyrimas patvirtina teorines mokslininkų ižvalgas apie bibliotekininkų profesijos transformacijas ir su tuo susijusius iššǔkius. Intensyviausi pokyčiai vykta dẻl sparčiai kintančių technologijų, tačiau Lietuvos bibliotekininkai susiduria ir su politinių pertvarkų, ekonominės raidos netolygumų, konkurencijos apraiškomis. Viešosios bibliotekos vis labiau imasi lyderystès bendruomenèse vaidmens, siekia geriau pažinti ir atitikti bendruomenès lūkesčius, nors šioje srityje pripažįsta turinčios tobulinti kompetencijas ir siekti profesionalumo. Teminès analizės metodu suformuota bibliotekininko profesionalumą žyminčių kompetencijų schema rodo, kad didžiąja dalimi profesionalumą tyrimo dalyviai suvokia per bendrąsias tradicines ir inovatyvias, kūrybiškumą bei orientaciją i lankytoją apibrěžiančias kompetencijas.

Ilgaamžes tradicijas turinti biblioteka keičiasi, nors joje išlieka institucijos išskirtinumą formuojančios veiklos, suteikiant prieigą prie informacijos. Tema Svarbiausios veiklos bibliotekoje atskleidžia, kaip keičiasi suvokimas apie esmines bibliotekos funkcijas, veiklų svarbos pirmenybiškumo suvokimą. Teorineje dalyje pristatytos Candy Hillenbrand ${ }^{36}$ ir James Castiglione ${ }^{37}$ institucijų kaitos tendencijos, susijusios su naujųjų medijų ir technologijų ìvaldymo svarba, patvirtina tyrimo dalyvių suvokimą apie bibliotekos esminių veiklų skirstymą $\mathfrak{i} 1$ 1) tradicines (ilgai trunkančias, nuo seno bibliotekai būdingas) ir 2) inovatyvias veiklas (susijusias ne tik su naujujų technologiju taikymu, bet ir naujomis anksčiau bibliotekai nebūdingomis ar mažiau būdingomis veiklomis). Kad išliktų dermè ir būtų puoselèjama harmonija tarp šių tendencijų, turi būti tam tikros sąlygos, pavyzdžiui, turi ịvykti suvokimo transformacija bibliotekininkų sąmonejje.

Kaip inovatyvios Lietuvoje suvokiamos ne tik naujomis technologijomis paremtos veiklos, bet ir plačiau - siekiai geriau pažinti bendruomenę ir siūlyti jai aktualias paslaugas. Inovatyviomis veiklomis Ł̣vardijamos išsiplètusios bibliotekos kultūrinès-edukacinès funkcijos, renginių organizavimas, su papildomomis veiklomis susiję projektai. Renginių organizavimas ir edukacijos turi tradicijas bibliotekose, tačiau palyginti su ankstesniais laikotarpiais šios veiklos labai išplètotos, pasikeitusios jų formos. Inovacijos pasireiškia per bibliotekos, kaip demokratinès erdvės visiems, plètojimą, naujų veiklų, kurių pagrindu ¡̇ biblioteką pritraukiama daugiau žmonių, tikslingas paieškas. Inovatyvus yra požiūris, kad organizuojamos veiklos padètų žmonèms tobulèti, jų gerai savijautai.

Be galo svarbu, kad pasikeistų darbuotojų nuostata dèl būtinybès keistis, tobulinti savo asmenybę, atitikti laiko dvasią, o ne vien išlaikyti esamą status quo. Pasikeisti turi ne tik bibliotekininkų, bet ir bibliotekų steigèjų bei valdytojų suvokimas. Šiuo atveju svarbu įrodyti savo reikalingumą ir naudą bendruomenei, paneigiant „pinigų siurblių“ epitetą. Tyrimo dalyviai pabrèžia, kad transformacijas skatina besikeičiantys bibliotekų pastatai ir vidinis dizainas - pokyčiai, ívykę dèl šalyje vykdomos bibliotekų modernizavimo programos. Neišvengiama transformacijos sąlyga tampa tarpinstitucinis bendradarbiavimas. Bendrai veiklai susijungia ne tik apskričių, rajoninès viešosios, bet ir skirtingų priklausomybių bibliotekos, jos vis labiau bendradarbiauja su kitomis vietovèje įsikūrusiomis institucijomis. Kartais tarp jų vyksta konkurencija dèl to paties kultūros paslaugų naudotojo, tai skatina bibliotekas siekti paslaugų kokybės ir ją išlaikyti. Nedidelèse vietovèse besiplečiančios bibliotekos veiklų tendencijos pasireiškia paslaugų dubliavimu, o tai kelia išnykimo grèsmę ir skatina biblioteką apibrèžti savo identitetą. Svarbi kokybiško veiklų organizavimo sąlyga - papildomo finansavimo paieškos, nes iš biudžeto gaunamo minimalaus finansavimo veiklų ivairovei nepakanka.

Tema Profesionalumo kaitos veiksniai, iššūkiai ir kliūtys atskleidžiama per objektyvius ir ịtaką darančius veiksnius, pokyčių kelyje sprendžiamus iššǔkius ir patiriamas kliūtis. Tai atitinka teorinèje dalyje minètų D. F. Kohlo ${ }^{38}$, B. U. Zano ${ }^{39}$ nuostatas, kad bibliotekos personalui tenka ne kartą keistis ir aplinkos

Žr. Hillenbrand, C. Librarianship in the 21st Century - Crisis or Transformation?, p. 164-181.

Žr. Castiglione, J. Environmental Scanning: an Essential Tool for Twenty First Century Librarianship, p. 528-536.

Žr. Kohl, D. F. Knowledge Life Cycles: Renewal and Obsolescence, p. 374-381.

3 Žr. Zan, B. U. Familiarity of Information and Records Management Students to Web 2.0 Tools: A Case Study on Blog, p. 143-151. 
pokyčiai verčia labai rimtai reaguoti ị besikeičiančias realijas. Šias nuostatas papildo tyrèjos M. Haigh mintis, kad ne tik technologiniai, bet ir ideologiniai pokyčiai daro įtaką profesijos kaitai ${ }^{40}$. Tyrimo rezultatai patvirtina, kad vienas svarbiausių profesinès transformacijos veiksnių - aplinkoje vykstantys pokyčiai ir ju daromas spaudimas keistis. Netolimoje praeityje tai buvo politinès ir valdymo sistemos pokyčiai, atsiradusios kompiuterinès technologijos. Dabar - dèl globalių pokyčių besikeičiantys bibliotekos skaitytojų ir lankytojų poreikiai, elgesys, medijų pasikeitimai, kintančios bibliotekų erdvės, išsiplètusi bibliotekoje besilankančiu asmenų geografija ir su tuo susijusi tarpkultūrinès komunikacijos plètra. Kaitą atspindi besiformuojantis bibliotekininkų profesionalumo bruožas - noras pagelbèti kitiems, būti ịvertintiems, pasididžiavimas savo institucija. Kita vertus, profesionalumo transformacijai didelę ịtaką daro buvęs (nemaža dalimi išlikęs) bibliotekos darbuotojų „ramaus darbo lūkestis“, būdingas net ir naujai i bibliotekininko pareigas pretenduojantiems asmenims, ir daugelio bibliotekininkų polinkis ị humanitarinius mokslus. Todèl dažnam bibliotekininkui būdinga technologijų įvaldymo baimè ir pasipriešinimas tam. Svarbūs yra naujovių adaptavimo kolektyve būdai, vienas iš jų - tęstinis kompetencijų tobulinimas. Neatsitiktinai mokslininkai R. Vaaganas ir S. Holmas savo tyrime akcentuoja stereotipų keliamą grèsmę profesijos vystymuisi, nuogąstauja dèl naujų stereotipų, keliančių grèsmę pamatinei bibliotekų filosofijai ir vertybèms, įsigalejjimo ${ }^{41}$. Stereotipai šio tyrimo dalyvių sampratoje pasireiškia „ramaus darbo lūkesčiais", pasipriešinimu kaitai, taip pat ir technologinei.

Didelę reikšmę profesionalumui gerinti turi profesijos lyderiai, nukreipiantys kaitai. Su didele pagarba tyrimo dalyviai mini profesorès Audronès Glosienès įtaką. Bibliotekų kaitai didelę reikšmę turèjo didieji tarptautiniai projektai, suteikę galimybių ne tik atnaujinti technologijas, bet ir kelti kvalifikaciją profesijos srityje, taip pat ugdyti bendrąsias kompetencijas. Tai atitinka C. Johnson atlikto tyrimo, skatinančio bibliotekininkus imtis lyderio bendruomenèse (taip pat ir profesinėse bendruomenėse) vaidmens, mintis ${ }^{42}$.

Profesionalumo kaita susijusi su finansais. Bibliotekininkų atlyginimai auga per mažai, nors per nepriklausomybės laikotarpi yra pokyčių i teigiamą pusę, tačiau esamoje situacijoje biblioteka negali konkuruoti dèl kūrybingų, motyvuotų inovatyvioms veikloms asmenų pritraukimo. Vis dar kalbame apie tai, kad bibliotekininko gaunamas atlyginimas neužtikrina oraus žmogaus fiziologinių ir saugumo poreikių. Per profesines organizacijas išsikovotas pagrindinių bibliotekos veikloms būtinų finansų apibrèžtumas, tačiau per krizę pažadèti rodikliai sumažèjo daugiau nei tris kartus. Finansų įtaka bibliotekų veiklai analizuojama ir teorijoje, tačiau pabrèžiamas kitas aspektas. JAV mokslininkas J. Castiglione akcentuoja, kad visame pasaulyje bibliotekoms tenka susidurti su finansinių išteklių apribojimais ir juridinių asmenų spaudimu ${ }^{43}$.

Tarp minimų ǐššūkių, kuriuos bibliotekininkai patiria pokyčių kelyje ir imasi juos spręsti, pirmiausia ìvardijamas nauju technologiju įvaldymas. Pabrèžiamas poreikis bibliotekose įdarbinti IT specialistus, kurie veiktų kartu su bibliotekininkais, padètų jiems ịgyti reikiamus igūdžius. Susiduriama su problemomis, susijusiomis su įrangą pagal projektus pateikiančiais, bet mokymų nesuteikiančiais edukatoriais. Bibliotekos savarankiškai ieško sprendimų, nors pageidautų centralizuotai organizuojamų mokymų.

Susiduriama su generaciju vertingumo pokyčiais, kai ilgamečiai darbuotojai nesulaukia lauktos pagarbos, nes jiems sunkiau igyti reikiamus naujus gebejjimus, o senų nepakanka. Iššūkiu tampa pritraukti jaunų, motyvuotų dirbti žmonių ị menkai mokamas pareigas, o ilgamečiai darbuotojai nelinkę pripažinti jaunimo vertingumo dèl profesinès patirties ir tradicinių žinių stokos. Todèl administracijai tenka spręsti iššūkius, randant darbuotojui tinkamą vietą, kurioje jis galètų atsiskleisti kaip kūrybingas darbuotojas.

\footnotetext{
Žr. Haigh, M. Escaping Lenin's library: Library and Information Science education in independent Ukraine, p. 75.

Plačiau žr. Vaagan, R.; Holm, S. Professional Values in Norwegian Librarianship, p. 213-217.

Plg. Johnson. C. A. Library and Information Science Education in Developing Countries. The International Information \& Library Review, 2007, Vol. 39, No. 2, p. 64-71.

43 Plačiau žr. Castiglione, J. Environmental Scanning: an Essential Tool for Twenty First Century Librarianship, p. 528-536.
} 
Kita vertus, plečiantis bibliotekos veikloms ir mažejant turinčiu bibliotekinị išsilavinimą, vis daugiau įdarbinamų asmenų yra baigę kitos srities mokslus. Susiduriama su iššǔkiu jiems perteikti esmines bibliotekininkystès žinias, o ilgamečiams bibliotekininkams iššūkiu tampa perprasti naujas veiklas, atlikti papildomas ar pasikeitusias funkcijas. Pažymima, kad igyti reikalingų veiklai kompetencijų ir jas tobulinti irgi yra iššǔkis, nes šalyje nèra vienos tęstinès kompetencijų tobulinimo (kvalifikacijos kèlimo) sistemos. Pokyčiai įvyko dẻl asmeninių siekių igyti kompetencijas: dar neseniai buvo nemažai nelinkusių tobulèti, o dabar norinčių mokytis yra daugiau nei galimybių juos išsiųsti kelti kvalifikacijos. Taikomi ir netradiciniai kompetencijų tobulinimo (kvalifikacijos kèlimo) metodai, pavyzdžiui, savanorių iš kitų šalių pasikvietimas ị biblioteką.

Veiklų organizavimo iššūkis bibliotekoms yra rinkodaros principų taikymas, tai keičia patị požiūrị i veiklas, skatina savarankiškai kurti projektus, atlikti tyrimus, geriau pažinti bendruomenę ir plèsti ịprastines kasdienes veiklas. Sprendžiami iššūkiai sudaro sąlygas keisti savivaldos nuomonę apie bibliotekos reikšmingumą, jos teikiamą naudą, leidžia bibliotekoms išlikti patrauklioms ir reikalingoms. Tai patvirtina minetų J. Castiglione ir C. A. Johnsono tyrimuose pristatomi lyderiavimo ir rentabilumo siekių aspektai bibliotekininkams siekiant veiklos profesionalumo ${ }^{44}$.

Didžiausiomis profesionalumo transformacijų kliūtimis ịvardijamas kai kurių bibliotekininkų konservatyvumas ir pasipriešinimas naujovèms, kurị îveikti yra labai sudètinga. Viena iš kliūčių - lètai vykstantis kolektyvo atsinaujinimas, nes išlieka gaji tradicija dirbti ir sulaukus pensinio amžiaus. Tai tampa kliūtimi, jeigu ilgamečiai darbuotojai profesionalumą supranta labai ribotai ir konservatyviai (baigiau bibliotekininkystės studijas, manęs to nemokè). Motyvuoti bibliotekininkus naujoms veikloms ar papildomoms funkcijoms turi vadovai, susiduriantys su probleminiu siekiu „daugiau moketi gerai dirbančiam personalui", nes galimybių tam mažai. Viena iš siūlomų problemos sprendimo galimybių - atestacija ir jos rezultatų sąsajos su atlyginimo koeficientu. Šios tyrimo dalyvių iškeltos problemos nepavyko identifikuoti kitų tyrèjų darbuose.

Kliūtis siekti profesionalumo - reikiamų mokymu kompetencijoms igyti ir tobulinti trūkumas, kvalifikuotų specialistų stoka rinkoje. Gresianti kliūtis profesionalumui - atsitiktiniai, profesijai neatsidave vadovai, kuriu gali padaugèti dèl ribotų direktorių kadencijų.

Kliūtis gerinti profesionalumą yra bendros bibliotekų politikos stoka, o juk turètų būti apibrèžtas bibliotekos identitetas, vystymosi kryptys, galima kooperacija ir bendros veiklos. Pačioms bibliotekoms siekiant profesionalumo kliūtimi tampa negebejimas tinkamai pristatyti savo veiklas, jų teikiamą naudą visuomenei. İvardytas kliūtis galima identifikuoti ir teorinejje sampratoje cituojamuose moksliniuosepraktiniuose darbuose.

Temoje Profesionaluma išreiškiančios kompetencijos jos aptariamos skirstant ị 1) tradicines / klasikines profesijai būdingas kompetencijas; 2) inovatyvioms veikloms būtinas kompetencijas bei 3) profesionaliai dirbančiam bibliotekininkui būdingas asmenines savybes / bendruosius gebejjimus. Pabrěžiama sąlygų profesionalumo raiškai svarba.

Bibliotekininko profesionalumą sudaro keleto blokų (kompleksinių vienetų) tarpusavyje susijusios kompetencijos ir sąlygos profesionalumui reikštis. Profesionalus bibliotekininkas turi išlaikyti profesionalumo branduolị sudarančias kompetencijas, kurios būdingos ilgas istorines tradicijas turinčios bibliotekos institucijos darbuotojams (sąrašas pateikiamas 1 schemoje). Tradicines kompetencijas galima skirstyti ị bendrasias (jas turi igyti visi bibliotekos darbuotojai) ir specifines (būdingas konkrečiai darbo vietai). Svarbu igyti bendrąsias bibliotekininko kompetencijas, o specifines galima tobulinti ir pačioje darbo vietoje, keičiantis veiklų būdams ar perimant pareigas iš išeinančiu iš darbo. Pasireiškia skirtumas tarp ilgas tradicijas turinčių kompetencijų (pavyzdžiui, komplektavimo) ir išskirtinai dinamiškų darbo vietų (pavyzdžiui, darbas su jaunimu), kuriose tenka nuolat atnaujinti kompetencijas.

44 Žr. Castiglione, J. Environmental Scanning: an Essential Tool for Twenty First Century Librarianship, p. 528-536; Johnson, C. A. Library and Information Science Education in Developing Countries, p. 64-71. 
Inovatyviu veiklu kompetencijos tiriamuoju laikotarpiu tampa išskirtinai aktualios ir būtinos ne tik plečiant savo veiklas, bet ir teikiant klasikines bibliotekų paslaugas. Svarbiausia kompetencija - išmanyti technologijas, nuolat atnaujinti informacinị ir medijų raštingumą. Tai tiesiogiai susiję su kita svarbia tampančia bibliotekine kompetencija - edukaciniu mokymu organizavimu ir vedimu. Vykdomos edukacijos turi būti patrauklios, reikalingos bendruomenei. Jos neapsiriboja technologiniu raštingumu, bet šioje srityje bibliotekos teikia pagalbą bendruomenei, suteikdamos daugiau galimybių informacijos prieigai ir kasdieniam gyvenimui. Svarbu naudoti technologijas ne tik senjorams mokyti, bet ir jaunų žmonių skaitymui skatinti.

Kultūrinès, edukacinès funkcijų plètra bibliotekose reikalauja bibliotekininkams būti kompetentingiems rengiant ir valdant projektus. Inovatyvumas informavimo veikloje reikalauja iš bibliotekininko ne tik modernaus informacinio raštingumo, bet ir plataus akiračio, gebejjimo individualiai konsultuoti ne tik pagal užklausas iš bibliotekos fondo. Inovatyvi daugeliui bibliotekų darbuotojų yra veiklos organizavimo pagal rinkodaros principus kompetencija: moketi atlikti tyrimus, analizuoti informaciją, pagal ją reaguoti ir veikti. Inovatyvia kompetencija bibliotekininkams tampa gebejimai tinkamai komunikuoti su visu socialiniu sluoksniu ir grupiu atstovais. Sëkmingam bibliotekos įvaizdžiui kurti ir išlaikyti bibliotekininkams svarbu profesionaliai komunikuoti su politikais - gebėti palaikyti demokratijos nuostatas, suteikti bendruomenès nariams teisę būti išklausytiems ir pasirinkti.

I specifinių kompetencijų reikalaujančias pareigas turi būti priimami jas turintys specialistai - informacinių technologijų, ryšių su visuomene, renginių organizavimo profesionalai.

Svarbios profesionalumui yra asmenines bibliotekininko kompetencijos, dažnai ịvardijamos kaip bendrieji gebejjimai ar asmens bruožai. Svarbiausia yra asmens motyvacija dirbti ir pasiekti rezultatus, o tai tiesiogiai susiję su išprusimu. Tai lojalumas ir pagarba savo profesijai, gebejjimas išlaikyti lygị, žinių siekis ir atsakomybės prisièmimas, pasiryžimas ịveikti sunkumus. Išskirtinai svarbios profesionalumui tampa komunikacinès savybès, noras bendrauti, empatija, lankstumas ir per tai pasireiškiantys gebëjimai pritraukti lankytojus, atstovauti savo institucijai. Būtina savybè - tolerancija ir etikos laikymasis, gebèjimai turimas kompetencijas taikyti naujose veiklose.

Asmeninių savybių reikšmę profesijai pabréžia ir teoretikai. Minètos J. Bronstein tyrime ${ }^{45}$ jos sudaro atskirą kompleksinị bendros struktūros vienetą. Pristatomo tyrimo rezultatai tai patvirtina. Mąstoma apie bendruosius gebejimus, kuriuos turi tobulinti bibliotekininkai, nes jais turi pasižymèti profesionaliai atliekantys pareigas darbuotojai. Bendrajame bibliotekininko profesionalumą nurodančių kompetenciju sąraše bendrieji gebejjimai išvardijami Kürybiškumo ir orientacijos į lankytoja reikalaujančiu inovatyviu veiklu kompetenciju kompleksiniame vienete.

Atskirų darbuotojų profesionalumas sudaro sąlygas veikti kartu ir profesionaliai atstovauti institucijai. Bendri tikslai, bendraminčiu siekiai veiklai suteikia sinergijos. Viena iš profesionalumo sąlygų yra universitetinis darbuotojų išsilavinimas. Daugelis tyrimo dalyvių pirmenybę teikia profesijos srities išsilavinimui, pritaria bendro kompetenciju rinkinio sudarymui, nuo kurio reikètų atsispirti siekiant tolesnio profesionalumo vystymo ir būti pasirengusiam priimti naujoves. Kita vertus, darbdaviai turi siekti atskleisti žmogu, rasti vietą, kurioje geriausiai atsiskleidžia jo kompetencijos. Profesionalus bibliotekininkas turi gebèti pritraukti lëšú, rašyti sèkmingus projektus, nes tik taip gali būti tobulinamos reikiamos kompetencijos ir vystomos inovatyvios veiklos. Profesionalumui reikštis padeda modernizuotos, atsinaujinančios bibliotekos, ị kurias lankytojams smagu ateiti, skatinamas darbuotoju pasididžiavimas institucija ir motyvacija siekti profesionalumo. Ši potemè parengta dèl to, kad tyrimo dalyviai pabrèžè ir ịvardijo, kas trukdo ir kas padeda profesionalumui reikštis. Kita vertus, kaip profesionalumo sąlyga yra suvokiamas poreikis tobulinti asmenybę, bendrąsias kompetencijas ir galimybė gražinti (atnaujinti, modernizuoti) pačias bibliotekas.

Bronstein, J. An Exploration of the Library and Information Science Professional Skills: An Israeli Perspective, p. $130-138$. 
1 schema. Lietuvos bibliotekininko profesionaluma žyminčiu kompetenciju klasifikacija

\section{Tradicinès profesinès kompetencijos}

Bendrosios profesinès kompetencijos

\section{Bendrieji gebẻjimai ir ịūdžiai:}

raštvedyba, informacinis ir technologinis raštingumas,

tekstų kūrimas,

literatūros išmanymas, gebejjimas populiarinti

knygą,

užsienio kalbų žinios.

etikos nuostatos ir jų laikymasis; tolerancija.

Komunikaciniai gebejjimai ir igūdžiai:

gebejjimas bendrauti su įvairiomis vartotojų grupėmis (vaikais, jaunimu, senjorais, specialiųų poreikių turinčiais žmonėmis).

Pradinès bibliotekininkystès žinios, gebejjimai ir igūdžiai:

a) bibliotekų sistemos veikimo suvokimas,

b) gebejimas dirbti LIBIS,

c) gebejjimas dirbti su duomenų bazèmis,

d) UDK išmanymas,

e) informacijos valdymo pagrindai:

- informacijos atranka,

- informacijos sisteminimas,

- informacijos apdorojimas (šifrų suteikimas,

aprašymas, sustatymas ir kt.),

f) konsultavimas pagal užklausas.
Specifinès profesinių kompetencijų sritys

- komplektavimas,

- dalykinimas,

- sisteminimas,

- bibliografinių įrašų rengimas,

- elektroninio katalogo palaikymas,

- kraštotyros veikla.

Inovatyvioms veikloms reikalingos kompetencijos

Technologijų išmanymas

\section{Informacinis ir medijų raštingumas:}

IKT naudojimo igūdžiai,

tikslinga informacijos paieška,

technologinis raštingumas,

gebejimai rasti ir atrinkti nauja esminę kokybiška

informaciją,

greita orientacija ir naujovių perpratimas.
Kūrybiškumas ir orientacija ị lankytoją

Vadybinès kompetencijos:

krizinių situacijų valdymas,

atstovavimas bibliotekai,

rinkodaros tyrimu organizavimas ir atlikimas,

efektyvus vadovavimas, gebejimas motyvuoti ir atskleisti

darbuotojus,

strateginis mąstymas,

gebejjimas panaudoti skirtingų kartų privalumus,

atsakomybès prisiemimas.

Asmeninès savybès / bendrieji igūdžiai:

lankstumas veikloje,

kultūros pažinimo poreikis ir žingeidumas,

domejimasis profesinèmis naujovèmis,

pusiausvyra tarp technologinio raštingumo ir naujos lite-

ratūros išmanymo,

kompetencijų sinergija (žinių taikymas, rengiant projektus); gebejjimai bendradarbiauti,

optimistinis nusiteikimas mokyti,

orientacija vietovès kultūrinejje aplinkoje,

pasiryžimas įveikti sunkumus, 


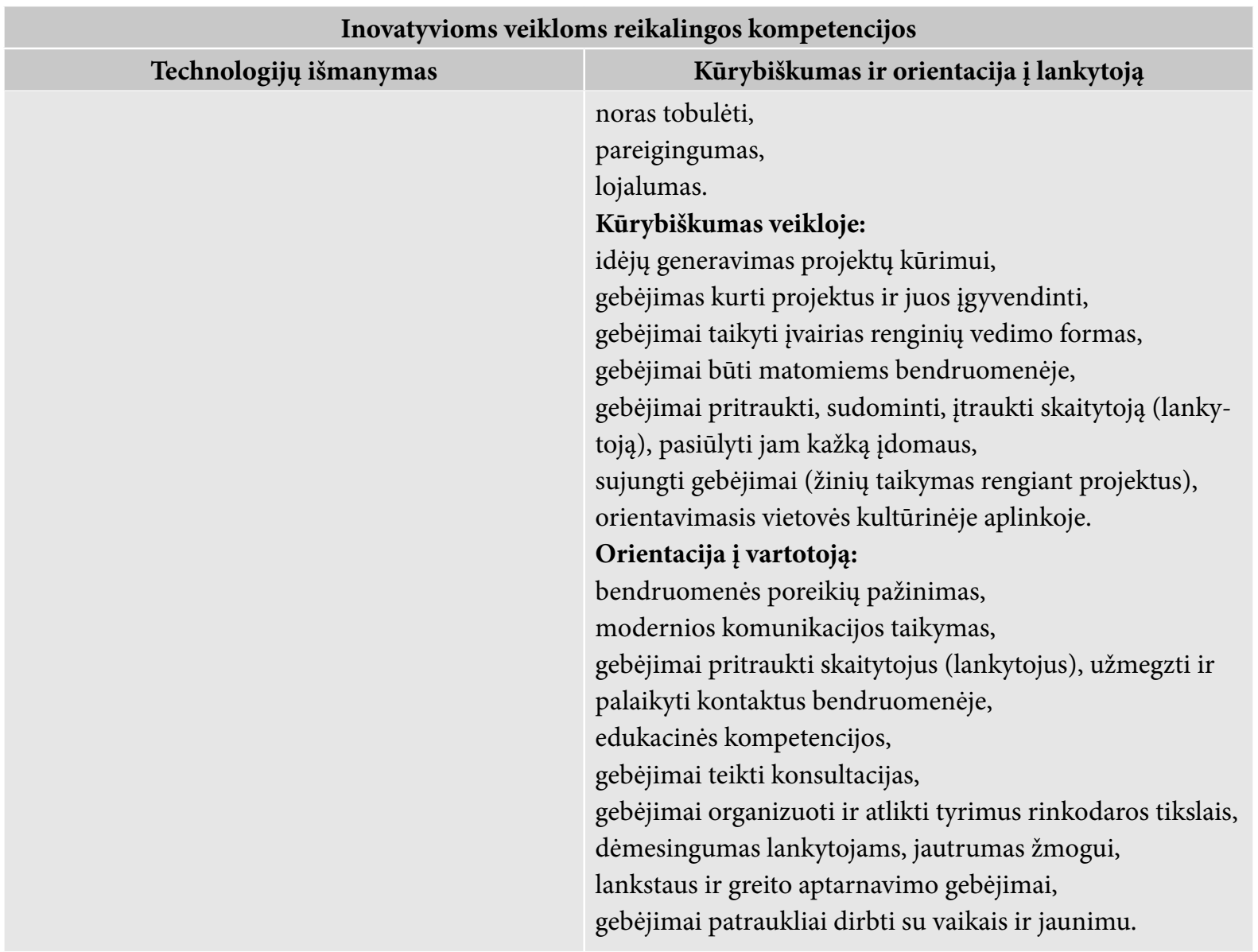

Schema sudarè tyrimo autorè, remdamasi apibendrintais interviu su tyrimo dalyviais duomenimis.

Tema Profesionalumo reikalavimai atskleidžiama analizuojant administracijos keliamus reikalavimus priimant ị darbą bibliotekoje ir apmąstant jau dirbančių bibliotekoje asmenų kompetencijų tobulinimą, sistemos šiame procese būtinumą. Reikalavimų dirbantiems neapibrèžtumas suponuoja profesijos neapibrèžtumo problemą ir poreikị siekti profesijos tęstinumo.

Profesionalumo transformacijos labiau tiketinos, jeigu yra nustatyti profesionalumo reikalavimai. Minètame J. Bronstein 2015 metais atliktame tyrime Izraelyje, B. Boumarafi tyrime ${ }^{46}$ IFLA svetaineje informacija apie profesionalumo reikalavimus surinkta pagal darbo skelbimus. Minetais tyrimais siekta nustatyti praktikams aktualias kompetencijas ir jas integruoti ị bibliotekines aukštojo mokslo studiju programas. Darbo skelbimuose yra aiškus praktikų žvilgsnis, išreiškiantis pageidavimus, kokiomis kompetencijomis pasižymintis asmuo reikalingas bibliotekai. Tenka paminèti, kad Lietuvoje yra formalūs nuostatai dèl minimalių reikalavimų, ir jie išties yra minimalūs: universitetinis arba kolegijų lygio išsilavinimas. Daugiau reguliavimo nustatant profesionalumą šalies mastu bibliotekininkams nèra. Tiesa, formaliuose darbuotojų reikalavimuose numatytas finansinis atlygio aspektas, bet tik už toje pačioje institucijoje išdirbtą laiką. Darbo skelbimuose retai aptinkama informacija dèl pageidaujamo įdarbinti bibliotekininko, be to, šie skelbimai dažniausiai pateikiami elektroninèje erdvejje ir neišsaugojami ilgesni laiką, todèl pristatomame tyrime nuspręsta personalą administruojantiems specialistams pateikti klausimą dèl reikalavimų naujai įdarbinamiems asmenims bibliotekose.

Atsakymai rodo, kad džiaugiamasi dideliu pretendentu $\dot{z}$ pareigas skaičiumi. Tai rodo pokyčius, nes netolimoje praeityje taip nebuvo. Kai kurios bibliotekos neturi tradicijos viešai skelbti darbuotojo

Boumarafi, B. Linking Library Profession and the Market Place: Finding Connections for the Library in the Digital Environment, p. 1-8. 
paieškas, nes turi sukaupusios atsiųstu gyvenimo aprašymu ir paprastai naujus darbuotojus renkasi iš jų. Pabrezžiamas pavojus pasitikèti tik asmens atsiųstais dokumentais, juose ịrašytus kompetencijų faktus dauguma patikrina ir per pokalbị su pretendentais. Pastebima, kad iš daugelio pretendentu atsirinkti nelengva, nes kvalifikuotą specialistą ižvelgti per trumpą pokalbio laiką yra sudètinga, o nusivilti žmogumi, jau einančiu pareigas, yra sunku. Kartais nusiviliama srities studijas baigusiais specialistais, nes jie veikloje neatitinka lūkesčių.

Būti specialistu, turèti reikiamų kompetencijų labai svarbu visose srityse. Pažymima, kad bibliotekoje tai svarbu ne tik bibliotekininkams, bet ir kitų sričių specialistams - informacinių technologijų, ryšių su visuomene ir kt. Viena iš svarbiausių priimamo ị pareigas asmens savybių - būti motyvuotam dirbti, filialuose - pažinti bendruomenę. Didžiuosiuose miestuose svarstoma, kad nereikia darbo skelbimuose nurodyti minimalių reikalavimų, reikia užkelti kartelę - tada susirinks atitinkami pretendentai. Užsimenama, kad savivaldos viešosios bibliotekose kartais darbuotojus tenka priimti pagal steigéjo nurodymus. Atokiose vietovèse realiai žvelgiama ị situaciją, nesitikima "profesijos žvaigždžių“, džiaugiamasi pačių bendruomeniu pateiktomis rekomendacijomis.

Svarbiausias kriterijus administracijai formuluojant reikalavimus pretendentams eiti pareigas yra aukštasis išsilavinimas, daugelis pabrèžia, kad pirmenybè teikiama igijusiems srities išsilavinimą. Tačiau dauguma taip pat pasisako už tai, kad svarbiausia - turèti platu išsilavinima ir siekti žiniu, laikytis etikos. O pats išsilavinimas gali ir nebūti bibliotekinis, juo labiau kad jau jaučiama baigusiųju šiuolaikines bibliotekines studijas stoka. Išsilavinimo platumas svarbus asmens pasitikëjimui savo veikla ir igyta kompetencija nuolat atnaujinti žinias. Juk yra šalių (pavyzdžiui, Austrija), kuriose bibliotekininkai nerengiami, jie profesines kompetencijas iggyja dirbdami. Tačiau pretendentams ị pareigas keliami aukšti reikalavimai.

Isitikinti turimomis kompetencijomis būtina surengiant pokalbius su atrinktais pretendentais. Kartais pokalbis papildomas užduotimis, kurios atliekamos vietoje arba namie iki kito susitikimo. Taip pasimato žmogaus kürybiškumas. Pokalbiuose ir susitikimuose stebimos asmeninès savybès - empatija, atsakomybè, bendravimas. Per laisvą pokalbị pretendentas gali papildyti savo gyvenimo aprašymą, pristatyti, ką konkrečiai jis dirbo kitose institucijose arba kokị turi su skaitymu susijusị pomégị (pavyzdžiui, yra tinklaraščio autorius ar klubo vedejjas), taip paaiškejja jo išprusimas literatūros srityje. Filialuose, kuriuose išskirtinai glaudus ryšys su vietos gyventojais, ịdarbinant žmones atsiklausiama bendruomenés, issiklausoma ị pastabas.

Idarbinant bibliotekose, privalumą turi šis kompetencijų rinkinys (skliaustuose žymimas atsakymų pasikartojimų dažnis): kompiuterinis raštingumas (3), noras tobulèti (3), motyvacija dirbti (3), užsienio kalbų mokejjimas (3), gebejjimas bendrauti (3). Du kartus paminèta kompetencija - technologinis raštingumas (2). Dar išvardytos šios kompetencijos, kurioms teikiama pirmenybė įdarbinant ị bibliotekininko pareigas: kūrybiškumas, sklandi lietuviu kalba, gebejjimas kūrybingai rašyti, gebejjimai dirbti su vaikais (filialuose), motyvacija dirbti vienam (filialuose), patirtis bibliotekoje ar ieškomoje pozicijoje, entuziazmas, organizaciniai-vadybiniai gebejjimai, aukštasis išsilavinimas bibliotekininkystès srityje.

Profesionalumo reikalavimai turètų būti keliami ne tik priimant ị pareigas, bet ir jau ilgą laiką dirbantiems bibliotekininkams, tai galètų reikštis kaip tam tikra profesionalumo reikalavimų sistema, kurios tyrimo metu Lietuvoje nèra. Sistemos pagrindiniai elementai galètų būti tam tikras mechanizmas, kuriuo nustatomi iš anksto numatyti profesionalumo lygiai, jų susiejimas su bibliotekininko turimomis kompetencijomis. Svarbu turi būti kompetencijas panaudoti darbe ir pasiekti rezultatai. Dabar esami bibliotekininkų lygiai pagal pareigybių struktūrą ne visada atitinka realius darbuotojų pasiekimus.

Profesionalumo vystymo sistemos poreikis akivaizdus, kaip ir tai, kad tokią sistemą kurti ir ja rūpintis turi ir bibliotekas kuruojanti Kultūros ministerija, ir pati bibliotekinè bendruomenè. Vienas iš esminių dalykų profesionalumo vystymo sistemoje galètų būti nustatyti skirtingus pareigybiu profesionalumo lygius. Pasinaudojant kitų profesijų patirtimi, reikètų išskirti keleta profesiniu lygiu (nuo žemiausio iki aukščiausio profesionalumo lygio, pavyzdžiui, bibliotekininkas - metodininkas - ekspertas) ir pagal juos 
nustatyti reikalavimus. Taip būtų sudarytos karjeros sąlygos toje pačioje profesijoje ir galimybès didinti atlygi pagal pasiektus rezultatus.

Sistema turi būti kuriama kolegialiai, pasiremiant kitu šaliu patirtimi ir įtraukiant vietos specifiką. Reikètų sukurti tam tikra formulę, kuri apimtų išsilavinimą, kompetencijų naudojimą, pastangas, rezultatus, aptarnaujamos bendruomenès pasitenkinimą ir kt. ir būtų bendra visai šaliai. Profesionalumo lygių vertinimas galètų būti susijęs su periodiniu konkuravimu dèl darbo vietos, turètų būti nustatytas ir minimalus kasmetinis (ar tam tikro laikotarpio) profesionalumo vystymo reikalavimas (pavyzdžiui, dalyvauti metinëje profesinejje konferencijoje). Būtina profesionalumo sistemoje nustatytus lygius ir jų siekimą susieti su realia finansine paskata.

Profesionalumo sistemos elementai yra pastebimi tyrimo metu galiojančioje darbuotojų vertinimo už pasiektus rezultatus praktikoje. Vien pokalbis apie pasiektus rezultatus motyvuoja, priverčia darbuotojus pasitempti. Teoriškai metinis veiklos vertinimas siejamas su kintamąja atlyginimo dalimi, tačiau kol kas nustatytoje tvarkoje daug trūkumų, ypač tai, kad biudžete neskiriama konkrečių lèšų arba jos kinta (kasmet gali ir padidèti, ir sumažeti), o juo labiau kad vertinimas turi būti atliktas daug anksčiau, nei tampa aiškus ateinančių metų biudžetas.

Profesionalumo vystymo sistemoje atsiranda akivaizdus trūkumas - nelieka universitetinés bibliotekininkus rengiančios studiju programos, todèl kyla grèsmė prarasti profesijos žinių branduoli. Dabar bibliotekoje būtinas darbui žinios ir igūdžiai naujai ịdarbintiems bibliotekininkams perteikiami darbo vietoje, tačiau tai užima laiko, neapima viso branduolio žinių ir yra perteikiama neprofesionalių edukatorių. Būtina steigti bent podiplomines, išlyginamąsias ar kitokio profilio studijas, kuriomis būtiniausioms žinioms igyti galètų pasinaudoti kitos srities studijas baigę naujai įdarbinti bibliotekoje asmenys.

Akivaizdu, kad tobulinti kompetencijas / kelti kvalifikacija bütina tęstiniu büdu, kaskart keičiantis aplinkybèms, darbo profiliui, technologijoms. Tai tyrimo metu šalyje nevyksta arba vyksta chaotiškai. Nesant universitetinių bibliotekininkų profesijai skirtų studijų ir bibliotekose vis daugiau ịsidarbinant kitas studijų programas baigusių absolventų, akivaizdus poreikis šalyje turèti kompetenciju centrą, kuriame būtų tęstiniu būdu siūlomas perkvalifikavimas. I̦kūrus centrą, čia būtų organizuojamos ir koncentruotai perteikiamos bazinès bibliotekininkystès žinios bei igūdžiai. Studijos galètų pasibaigti kvalifikaciniu egzaminu, išduodant pažymėjimą dirbti bibliotekoje. Dabartinè praktika, kai kvalifikacijos kèlimo centrai yra apskričių bibliotekos, ne visada pasiteisina. Nors ji turi privalumų (netolimas atstumas, paprasta atvykti, priima ị stažuotes), akivaizdūs ir trūkumai. Pirmiausia jie pasireiškia projektiniu kvalifikacijos kèlimo finansavimu, kuris lemia proceso chaotiškumą ir nepakankamumą, juo labiau kad juntamas daugelio darbuotojų noras tobulinti kompetencijas (kelti kvalifikaciją), o to anksčiau nebūdavo. Kita vertus, tyrime dalyvavę bibliotekų vadovai pritaria savišvietai ir profesionalumo vystymui meistrystès keliu, igūdžius perimant darbo metu iš kito specialisto.

Neabejojant dèl profesionalumo vystymo sistemos poreikio, konstatuojama bendros šalies politikos šiuo klausimu stoka ir sistemos kūrimo atsakingumas ir ilgalaikiškumas. Ateina laikas, kai keičiasi specialistų kartos, o nesant profesijos studijų gresia nepakankamo baziniu profesijos igūdžiu adekvatumo problema. Svarbu tampa sukurti bazinių žinių ir igūdžių rinkinį, tęsti profesionalumui vystyti skirtus mokymus, kurti visas grandis apimančią kompetencijų vystymo sistemą. Iniciatyvos skatinama imtis Nacionalinès bibliotekos specialistus.

Išskirtinai svarbus vaidmuo bibliotekininkų profesionalumo vystymo sistemoje skiriamas finansams. Tai tarsi atskiras sistemos elementas, nuo kurio priklauso visos sistemos kokybe ir veiksmingumas. Kompetencijų vystymo sistema turi būti finansuojama iš biudžeto, nes tai svarbu kokybei. Dèl objektyvių priežasčių (mažèja gyventojų skaičius, todèl mažèja ir surenkamų mokesčių) bibliotekoms skiriamos lèšos mažèja. Kaip efektyviai paskirstyti turimus finansus, susiejant su profesionalumo vystymu, nenustatyta. Ivairuoja pasiūlymai, kaip siekti geresnio apmokëjimo gerai dirbantiems - nuo konkurencijos elementų įteisinimo aukščiausio lygio profesionalams iki priedų už pasiektus rezultatus reglamentavimo šalies 
mastu. Esama ir kitokios nuomonès šiuo klausimu: dèl bendros ekonominès situacijos turi būti ịteisintas kultūros darbuotojų atlyginimų kèlimas iki tokio lygio, kad bibliotekininkai nejaustų baimès dèl fiziologinių ir saugumo poreikių nepatenkinimo grèsmès. Tada būtų realu kalbėti apie gerai dirbančių finansinị skatinimą.

Profesionalumo vystymo sistemos ir aiškių reikalavimų profesionalumui stoka tiesiogiai susijusi su bibliotekininko profesijos tapatumo ir išlikimo grésme. Tarsi nyksta ribos tarp to, kas yra bibliotekininkas, o kas nèra. Tapatumo palaikymas siejamas su universitetinemis studijomis, siekiais išsaugoti savo profesiją, neleisti jai prarasti profesionalumo statuso. Jeigu nèra galimybių atnaujinti universitetines bibliotekininkystès studijas, būtina suformuoti rinkinį kompetencijų, apibrěžiančiu bibliotekininko profesijos išskirtinumą, numatyti keletą profesionalumo lygiu, ju siekimo büdus, tai koordinuojantị centrą. Grèsmè profesijos ir institucijų profesionalumo plètrai matoma ir per nepakankama finansinį skatinima už pasiektus rezultatus, ir per profesijai neatstovaujančiu direktoriu atejimą, iteisinus rajonų bibliotekų direktorių kadencijas.

Temoje Profesionalumo vystymas samprotaujama apie proceso priežastis ir sąlygas, aptariami kompetencijų vystymo būdai, ịvardijamos dirbantiems bibliotekininkams svarbios ir tobulinti reikalaujančios kompetencijos.

Profesionalumo vystymui įtaką daro priežastys, skatinančios šį procesą, ir sąlygos, nuo kurių priklauso vykstančių transformacijų greitis. Besikeičianti aplinka kelia ǐšǔkius bibliotekoms, siekiančioms išlikti reikalingoms bendruomenei. Tai anksčiau atliktuose tyrimuose pabrěžia ir kiti tyrëjai ${ }^{47}$. Nors bibliotekininkai ịprastai yra išsilavinę žmonès, reikia palaikyti turimą lygi, atnaujinti žinias ir igūdžius. I̦vykus politinès sistemos transformacijoms, bibliotekoms atsirado daugiau galimybių pritraukti lèšas naujoms veikloms, reaguoti į besikeičiančius bendruomenès poreikius. Ir naujas, ir tradicines paslaugas turi teikti profesionalūs darbuotojai, kitaip biblioteka taps nepaklausi. Svarbi profesionalumo sąlyga - organizuojami mokymai, taip pat paties bibliotekininko asmeninè motyvacija perprasti naujoves. J. Bronstein ${ }^{48}$ pabrèžia bibliotekininkų kompetencijų tęstinumą ir kaitą, būtinybę imtis naujų veiklos būdų.

Viena iš profesionalumą skatinančių priežasčių - profesijos lyderystė ir konkretus įstaigos vadovas. Tyrimo metu pasigendama profesinès lyderystès, stiprių, profesionalumą skatinančių asmenybių, kokia buvo minèta šviesaus atminimo profesorè Audronè Glosienè. Cituojant jos įdiegtas teorines paskatas, pritariama, kad pokyčiai bibliotekose turi būti gerai apmąstomi ir iggvendinami palengva, visada reikia numatyti žingsnius.

Igūdžiai dažniausiai ugdomi vietiniame biblioteku tinkle, dalijantis turimomis kompetencijomis. Ypač tai aktualu gerinant technologinị raštingumą, kai informacinių technologijų specialistai perteikia igūdžius darbuotojams, o šie moko bendruomenès narius. Praktikuojamas ir pasidalijimas žiniomis, pavieniam darbuotojui sugrịžus iš kitur organizuotų mokymų. Vis dèlto, tyrimo dalyvių nuomone, toks būdas neatstoja tikrụjų igūdžių, igyjamų gerai organizuotuose kursuose.

Daugiausia dèmesio skiriama naujai įdarbinamiems bibliotekininkams, kurie turi dalyvauti tam tikruose mokymuose vietoje: gilinamasi $\mathfrak{i}$ teisinius dokumentus, patirtis perimama meistrystès būdu dirbant kartu su patyrusiu specialistu.

Kompetencijos tiriamuoju laikotarpiu daugiausia ugdomos ir tobulinamos iš projektiniu lešú. Mokymai dažnai būna ịtraukti ị projektines veiklas, įsigyjant tam tikrą ịrangą, tačiau neretai jų nepakanka, trūksta sklandumo organizacijoje. Ne visada būna naudingi nuotoliniai mokymai, ypač susiję su technologijų ịvaldymu. Reikalingas ir konsultantas, kurio būtų galima paklausti iškilus problemai. Didžiausia bibliotekininkų profesionalumo vystymo transformacija ịvyko netolimoje praeityje, vykdant didžiuo-

Plačiau apie tai: Smalls, M. L. The Library Proffesion in the 21th Century: Transformation for Survival, p. 1-16; Castiglione, J. Environmental Scanning: An Essential Tool for Twenty First Century Librarianship, p. 528-536; Johnson. C. A. Library and Information Science Education in Developing Countries, p. 64-71; Zan, B. U. Familiarity of Information and Records Management Students to Web 2.0 Tools: A Case Study on Blog, p. 143-151; Gudauskas, R.; Lukoševičius, R.; Knopkuvienè, V. Lietuvos viešujų biblioteku darbuotojų kvalifikacijos kèlimo sistemos modelis.

$48 \check{Z}$ r. Bronstein, J. An Exploration of the Library and Information Science Professional Skills: An Israeli Perspective, p. 130-138. 
sius tarptautinius projektus. Pavyzdžiui, iš B. ir M. Gatesų fondo kompetencijoms igyti ir tobulinti buvo skirta daug lèšų ir bibliotekininkai igijo labai daug ne tik profesinių, bet ir bendrųjų kompetencijų. Vis dèlto tiriamuoju laikotarpiu mokymų nepakanka, jiems organizuoti trūksta bendro centro, užtikrinančio tęstinumą, sistemiškumą pagal skirtingus lygius ir skirtingus poreikius.

Vyrauja nuomonè, kad bibliotekininkas, kurio darbo aplinkoje daug informacijos, daugeli jam reikalingų žinių gali rasti ir perprasti savišvietos būdu, savarankiškai. Kompetencijas tobulinti padeda ir papildomos, ne visai tuo tikslu bibliotekoje organizuojamos priemonès, pavyzdžiui, savanorių pritraukimas. Taip mokomasi tarpkultūrinès komunikacijos, stiprinami užsienio kalbos vartojimo igūdžiai ir kt. Iš kitų sričių atėję nauji darbuotojai skatinami nuotoliniu būdu baigti bibliotekininkystei artimos srities studijas.

Vardijant trūkstamas ar reikalingas tobulinti dirbantiems bibliotekininkams kompetencijas, dažniausiai minimos bendravimo iggūdžių ir technologinio raštingumo kompetencijos (bendrosios ir konkrečios veiklos). Toliau pateikiamos ịvardytos dirbantiems bibliotekininkams būtinos gerinti kompetencijos, nurodant jų paminèjimo dažni .

Labiausiai pasigendama mokymų tokiomis temomis:

bendravimo igūižių lavinimas (5), kompiuterinio (technologinio) raštingumo lavinimas (5), užsienio kalbų igūdžių lavinimas (4), literatūros pažinimas, vertinimas (3), bendrakultūrinis lavinimas (kultūros konteksto pažinimas) (2), esminių žinių perteikimas naujai ịdarbintiems (2), raštvedybos ịūdžių lavinimas (2), teksto rašymo igūdžių lavinimas (2), darbo su skirtingomis tikslinėmis grupėmis, socialinès integracijos ịgūdžių lavinimas (2), darbo su neiggaliaisiais ịgūdžių lavinimas (2).

Paminèti trūkstami profesiniai mokymai:

LIBIS sistemos taikymo atnaujinimas, statistikos formos pildymas, skaitymo skatinimo ịūdžių ugdymas (suaugusiesiems ir vaikams), naujausios žinios apie pasaulio bibliotekininkystės tendencijas.

Paminèti trūkstami bendrụjų igūdžių mokymai:

lankstumo, motyvacijos ugdymas, konfliktų valdymo, viešo kalbẻjimo ịūdžių lavinimas, gebejjimų atstovauti bibliotekai ugdymas, edukacinių igūdžių ugdymas (suaugusiesiems ir vaikams), projektų rašymo ịgūdžių ugdymas, pasirengimas pokyčiams ir jų skatinimas, komandinio darbo ịgūdžių lavinimas.

Pabrež̌iamas tęstinio kompetencijų tobulinimo poreikis, atnaujinant ir gilinant igūdžius. Trūksta profesinių seminarų ilgamečiams darbuotojams, galimybių padiskutuoti, susitikus aptarti naujoves ir kylančias problemas.

Apibendrinant bibliotekų darbuotojams reikalingų kompetencijų tobulinimą pabrèžtina asmeninių bendruju gebejimų svarba ir būtinybè tęstiniu būdu atnaujinti profesines kompetencijas, taip gerinant profesionalumą. Gauti empirinio tyrimo rezultatai papildo straipsnio pirmoje dalyje eksplikuotą bibliotekininko profesijos sampratą, iliustruoja suvokimą apie šiai profesijai būdingų profesionalumo bruožų kaitą, darbo procese patiriamas kliūtis ir sprendžiamus iššūkius. Jie atitinka teorinejje dalyje suformuotas bibliotekininkystès ir bibliotekininko profesionalumo teorines nuostatas. Svarbiausių bibliotekos veiklu ir profesionalumą išreiškiančių kompetencijų temose yra aiškus poreikis ir būtinybè profesionalumui atitikti laiko dvasią. Profesionalumo reikalavimų ir profesionalumo vystymo temose išreiškiama pozicija, kad bibliotekų darbuotojų kompetencijos turi būti atnaujinamos, jos turi atitikti besikeičiančius bendruomenės poreikius, kintančią bibliotekininkystės filosofiją ir bibliotekos sampratą. Mąstant apie profesionalumo vystymo sistemą, pabrèžiama, kad sèkmingai bibliotekininko profesijos transformacijai reikalinga kompetencijų ugdymo ir tobulinimo sistema.

\section{Išvados ir rekomendacijos}

Atlikta bibliotekininko profesijos sampratos transformacijos analizė parodo, kad šiuolaikinio bibliotekininko igūdžių tipologiją sudaro keturios pagrindinès grupès: 1) informacijos teikimo / aprūpinimo igūdžių rinkinys; 2) informacijos organizavimo igūdžių rinkinys; 3) technologinių igūdžių rinkinys; 
4) asmeninių kompetencijų rinkinys. Empirinis nūdienos Lietuvos bibliotekininko profesionalumo ir kompetencijų vystymo tyrimas parodè, kad šios šalies bibliotekininko profesionalumo kaitai didelę itaką padarè didieji (B. ir M. Gatesų, Europos Sąjungos fondų iš dalies finansuoti) projektai, dèl kurių daugelis bibliotekininkų pakèlè kvalifikaciją, suvokẻ pokyčių svarbą, praplètė akiratị. Visgi bibliotekininko profesiją renkasi daugiausia humanitarinius polinkius turintys asmenys, todel jiems nelengva priimti profesijos pokyčius technologijų kryptimi. Itin svarbus jų profesionalumui yra profesijos lyderių vaidmuo. Ši esmini poveikị šiame procese turẻjo profesorè Audronė Glosienė. Konstatuotinas tokio rango lyderių trūkumas, nes sunyko profesijai skirtos aukštojo mokslo studijos ir nèra bendros profesionalumo sistemos politikos.

Iššǔkiai, kuriuos sprendžia bibliotekų vadovai, kyla iš globalių tendencijų (naujų technologijų kaita, generacijų vertingumo pokyčiai, rinkodaros taikymas pelno nesiekiančioms institucijoms) ir iš konkrečiu vietovès aktualijų (savivaldos suvokimo apie bibliotekos naudą kaita, kompetencijų tobulinimo galimybių nepakankamumas, konkurencija dèl to paties vartotojo). O profesionalumo kaitos kliūtys reiškiasi ne tik per asmens ribotumus (konservatyvumą, nepakankamą motyvaciją tobulèti ir kt.), bet ir per objektyviai patiriamą bendros bibliotekų politikos stoką, negebejjimą demonstruoti bendruomenei teikiamos naudos, apsiribojant suvokimu, kad skaitymo organizavimas pats savaime yra pakankama vertybè.

Tyrimas parodè, kad personalą valdantys administratoriai profesionalumą išreiškiančias kompetencijas priskiria klasikinèms (bendrosioms) arba inovatyvias veiklas paremiančioms kompetencijoms. Tradicinèmis, bibliotekų veiklos tęstinumą nurodančiomis kompetencijomis ịvardijami profesionalūs gebejjimai atlikti komplektavimo, dalykinimo, sisteminimo, bibliografinių ịrašų rengimo, elektroninio katalogo palaikymo, kraštotyrinès veiklos ir darbo su kultūros paveldu procesus. Daug plačiau vardijamos bendrosios profesinès kompetencijos, kurias turètų igyti visi bibliotekų darbuotojai. Tai plataus spektro gebejjimai, pradedant raštvedyba ir rašto kultūra, baigiant profesionalia informacijos atranka, gebejjimais populiarinti knygos kultūrą ir kt. Prie bendrųjų gebẻjimų priskiriamas ir UDK ar LIBIS išmanymas kaip būtinas žinojimo apie bibliotekos veiklos principus aspektas.

Inovatyvioms veikloms bibliotekose reikalingos kompetencijos suvokiamos daug plačiau nei tik naujụjų technologijų naudojimo igūdžiai, nors ir pabrèžiamas jų reikšmingumas. Inovatyvios kompetencijos, kuriomis turi pasižymèti profesionalūs bibliotekininkai, apima keletą blokų: 1) vadybinès kompetencijos, reikalingos ne tik bibliotekos direktoriui, bet ir kitiems vadybininkams, 2) kūrybiškumas bei 3) orientacija i lankytoją (skaitytoja), taip pat pridètinę vertę bibliotekos veiklai suteikiančios kompetencijos ir 4) asmenines darbuotoju savybès. Tai nurodo, kad šiuolaikinis profesionalus bibliotekininkas turi ne tik tobulinti kompetencijas (kelti kvalifikaciją), bet ir nuolat tobulinti asmenybę, būti nusiteikęs kūrybiškai veiklai, pažinti bendruomenès poreikius ir tarnauti bendruomenei. Antra vertus, jis turimus igūdžius turi pasitelkti ir realizuodamas atstovaujamos institucijos tikslus. Šios inovatyvioms veikloms reikalingos kompetencijos labiausiai atitinka teorinę šiuolaikinio bibliotekininko ịgūdžių tipologiją.

Bibliotekininkai yra išsilavinę žmonès, tačiau ir jiems reikalingas tęstinis ir sistemingas žinių ir igūdžių atnaujinimas, o to pasigendama. Šią problemą dar labiau pagilina ta aplinkybè, kad nykstant aukštojo mokslo bibliotekininkystès studijoms dirbti ị bibliotekas priimama vis daugiau nespecialistų. Dèl to rekomenduotina sukurti profesionalumo vystymo sistemą, apimančią įvairius profesionalumo lygius, jų nustatymo kriterijus ir sąsajas su atlygiu už darbą. Būtina sukurti profesijos išskirtinumą sudarančių žinių ir igūdžių branduolị, kurị turètų igyti visi bibliotekose naujai įdarbinami asmenys, o dirbantys bibliotekininkai galètų daryti karjerą savo srityje pagal visiems žinomą bendrą sąsają tarp igyjamų kompetencijų ir pasiektų dirbant tam tikrose pareigose rezultatų.

Tyrimas pateikia Lietuvos bibliotekininko profesionalumą žyminčių kompetencijų klasifikaciją (1 schema), kuri galètų būti naudinga tolesniam profesijos žinių bei igūdžių branduoliui formuoti. 


\section{Literatūra ir šaltiniai}

Augustinaitis, Arūnas, Macevičiūtè, Elena. Informacijos specialistų poreikio nustatymo kriterijai. Informacijos mokslai, 1996, t. 5, p. 9-20.

Baruchson-Arbib, Shifra; Bronstein, Jenny. A View to the Future of the Library and Information Science Profession: A Delphi Study. Journal of the American Society for Information Science and Technology, 2002, Vol. 53, No. 5, p. 397-408. DOI: https://doi.org/10.1002/asi.10051

Berger, Peter L.; Luckmann, Thomas. Socialinis tikrovés konstravimas: žinojimo sociologijos traktatas / iš anglų kalbos vertė A. Radžvilienè. Vilnius: Pradai, 1999.

Bibliotekininkystés ir informacijos studiju vadovas / Ats. redaktorè ir sudarytoja A. Glosienė. Vilnius: Vilniaus universiteto leidykla, 2009.

Boumarafi, Behdja. Linking Library Profession and the Market Place: Finding Connections for the Library in the Digital Environment. QScience Proceedings: The SLA-AGC 21st Annual Conference, 2015, Vol. 2015, 4, p. 1-8. DOI: https://doi.org/10.5339/qproc.2015.gsla.4

Bronstein, Jenny. An Exploration of the Library and Information Science Professional Skills: An Israeli Perspective. Library \& Information Science Research, 2015, Vol. 37, No. 2, p. 130-138. DOI: https://doi.org/10.1016/j. lisr.2015.02.003

Castiglione, James. Environmental Scanning: an Essential Tool for Twenty First Century Librarianship. Library Review, 2008, Vol. 57, No. 7, p. 528-536. DOI: https://doi.org/10.1108/00242530810894040

Glosienė, Audronė. Biblioteka informacijos politikos kontekste. Informacijos mokslai, 2000, t. 15, p. 11-27.

Gudauskas, Renaldas; Lukoševičius, Rimantas; Knopkuvienė, Vainora. Lietuvos viešujų biblioteku darbuotojų kvalifikacijos kélimo sistemos modelis. Vilnius: Lietuvos nacionalinė Martyno Mažzydo biblioteka, 2017. Prieiga per internetą: https://www.kulturostyrimai.lt/metai/2017/lietuvos-viesuju-biblioteku-darbuotoju-kvalifikacijos-kelimo-sistemos-modelio-sukurimas/

Grigas, Vincas. Bibliotekininko vaidmuo informacinio raštingumo ugdymo kontekste. Bibliografija 2010/2011, 2013, p. 68-79.

Gudavičius, Edvardas. Los Caprichos. Du tūkstantis devintieji. Vilnius: Aidai, 2015.

Haigh, Maria. Escaping Lenin's Library: Library and Information Science Education in Independent Ukraine. The International Information \& Library Review, 2007, Vol. 39, No. 2, p. 72-79. DOI: https://doi.org/10.1080/1057 2317.2007.10762735

Hillenbrand, Candy. Librarianship in the 21st Century - Crisis or Transformation? The Australian Library Journal, 2005, Vol. 54, No. 2, p. 164-181. DOI: https://doi.org/10.1080/00049670.2005.10721744

Johnson, Catherine A. Library and Information Science Education in Developing Countries. The International Information \& Library Review, 2007, Vol. 39, No. 2, p. 64-71.

doi.org/10.1080/10572317.2007.10762734

Kardelis, Kęstutis. Moksliniu tyrimu metodologija ir metodai. Vilnius: Mokslo ir enciklopedijų leidybos centras, 2016.

Kavaliauskienė, Vanda. Pažintis su profesija. Klaipèda: Klaipèdos universiteto leidykla, 2011.

Kohl, David F. Knowledge Life Cycles: Renewal and Obsolescence. El profesional de la información, 2009, Vol. 18, No. 4, p. 374-381. DOI: https://doi.org/10.3145/epi.2009.jul.03

Lietuvos biblioteku istatymas. Lietuvos Respublikos Seimas, 2004 (priimtas 1995). Prieiga per internetą: https://eseimas.lrs.lt/portal/legalAct/lt/TAD/TAIS.238641. Žiūrèta 2020 m. vasario $26 \mathrm{~d}$.

Lietuvos biblioteku statistika. 2018. Prieiga per internetą: https://www.lnb.lt/media/public/bibliotekininkui/statistika/statistika2017.pdf. Žiūrèta 2019 m. rugpjūčio 27 d.

Lietuvos biblioteku statistiniai duomenys. 2018. Prieiga per internetą: https://nb.lt/media/public/bibliotekininkui/ statistika/statistika2018.pdf 
Manžuch, Zinaida. Profesinè komunikacija teminiame bibliotekininkystės tinklaraštyje: atvejo analizè. Informacijos mokslai, 2010, t. 54, p. 115-138. DOI: https://doi.org/10.15388/Im.2010.0.3171

Mozūraitè, Vita. Laisva prieiga prie informacijos - iššūkis bibliotekininko etikai. Kultūros aktualijos. 2005, Nr. 4 (45), p. 15-17.

Navickienè, Žaneta; Žiemelis, Darius. Lietuvos teisèjų profesionalumo dimensijos: kvalifikacija, kompetencija ir asmeninès savybès. Teisé, 2015, t. 97, p. 183-199. DOI: https://doi.org/10.15388/Teise.2015.97.9832

Partridge, Helen; Menzies, Victoria; Lee, Julie; Munro, Carrie. The Contemporary Librarian: Skills, Knowledge and Attributes Required in a World of Emerging Technologies. Library \& Information Science Research, 2010, Vol. 32, No. 4, p. 265-271. DOI: https://doi.org/10.1016/j.lisr.2010.07.001

Poviliūnas, Arūnas; Žiliukaitè, Rūta; Beresnevičiūtè, Vida. Profesinès veiklos lauko tyrimas. Vilnius: Vilniaus universiteto leidykla, 2012.

Smalls, Mary L. The Library Proffesion in the 21th Century: Transformation for Survival. Paper presented at the Annual Meetingof the. Georgia Library Association (August, GA, October 25, 1985), p. 1-16. Prieiga per internetą: https://files.eric.ed.gov/fulltext/ED267818.pdf

Stasėnaitè, Violeta; Naujokienė, Laima. Informacijos paslaugų specialistų poreikio integralumas informacinės visuomenès plètroje pereinant ị skaitmeninę globalios atminties erdvę. Profesinès studijos: teorija ir praktika, 2012 , t. 9 , p. $123-133$.

Šermukšnyte, Rūta. Ar istorijos mokytojams Lietuvoje reikia akademinès istorijos ir akademinių istorikų? Istorija, 2020, t. 120, Nr. 4, p. 67-102. DOI: https://doi.org/10.15823/istorija.2020.120.4

Šurkuté, Roberta. Bibliotekininkų kvalifikacijos kèlimas ir kompetencijų plètra: Jungtinès Karalystės atvejis. Šiandien aktualu: straipsniu rinkinys bibliotekininkams, 2019, Nr. 1 (60), p. 52-62.

Vaagan, Robert; Holm, Sigrid. Professional Values in Norwegian Librarianship. New Library World, 2004, Vol. 105, No. 1200/1201, p. 213-217. DOI: https://doi.org/10.1108/03074800410536649

Vårheim, Andreas; Ide, Eisaku; Iju Moriano. The Library Profession under Pressure in Japan: Change in the Construction State. Journal of Librarianship and Information Science, 2013, Vol. 45, No. 3, p. 248-253. DOI: https:// doi.org/10.1177/0961000612456866

Weber, Max. Mokslas kaip profesinis pašaukimas / iš vokiečių k. vertė Z. Norkus. Problemos, 1990, t. 42, p. 69-82. Doi: https://doi.org/10.15388/Problemos.1990.42.7107

Zan, Burcu Umut. Familiarity of Information and Records Management Students to Web 2.0 Tools: A Case Study on Blog. Proceedings of Global Learn Berlin 2015: Global Conference on Learning and Technology, 2015 April 16-17, p. 143-151. Prieiga per internetą: https://www.learntechlib.org/primary/p/150857/

Žydžiūnaitè, Vilma. Qualitative Diagnostics of Professional Identity Development in Vocational Education and Training: Congruences and Disconnections. Education-Line, 2005, p. 1-20. Prieiga per internetą: http://www. leeds.ac.uk/educol/documents/142829.htm

Žydžiūnaitè, Vilma; Sabaliauskas, Stanislav. Kokybiniai tyrimai: principai ir metodai. Vilnius: Vaga, 2017.

Žmogiškasis kapitalas Lietuvoje 2019: kryptis - ateities darbo rinka / apžvalgą parengè: G. Jakštas, V. Kuodytė, B. Leiputè, G. Padvilikis, M. Palevič, D. Požèla, L. Sabulytè, P. Simanavičius. Vilnius: Mokslo ir studijų stebėsenos ir analizès centras, 2019. Prieiga per internetą: https://strata.gov.lt/images/tyrimai/20191231_zmogiskasis_kapitalas_lietuvoje.pdf 